DESEMPENHO DE ENVOLTÓRIOS NA EFICIÊNCIA DA

DRENAGEM DE UM SOLO COM DRENOS TUBULARES

ANTONIO AUGUSTO ALVES PEREIRA

Orientador: PrOf. Dr. DECIO EUGENIO CRUCIANI

Dissertação apresentada à Escola Superior de Agricultura "Luiz de Queiróz", da Universidade de São Paulo, para obtenção do título de Mestre em Irrigação e Drenagem.

PIRACICABA

Estado de São Paulo - Brasil

Maio, 1988 
A meus pais

JOAQUIM E ELVIRA

DEDICO .

A minha esposa

M IRENE

OFEREÇO. 


\section{AGRADECIMENTOS}

A Deus, pela fé e perseverança concedida em todos os momentos.

Ao Prof. Dr. Décio Eugênio Cruciani pela orientação, apoio e amizade no decorrer do curso e na orientação deste tra balho.

Aos Professores Luiz Renato D'Agostini e Zeferino Pedro Sachet e ao funcionário Luiz Gustavo Pacheco, da UFSC, pe la colaboração inestimável.

Aos Professores do Departamento de Engenharia Rural da ESALQ pela contribuição à nossa formação.

A Todos os amigos que colaboraram na elaboração do trabaIho, com sugestões, elaboração de desenhos, datilografia e palavras de incentivo. 


\section{INDICE}

Pāgina

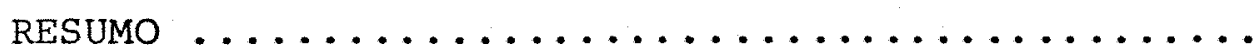

ix

SUMARY

$x i i$

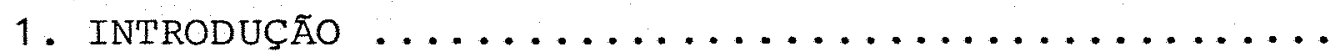

2. REVISÃo DE IITERATURA .................. 03

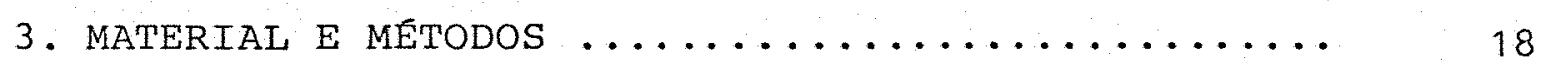

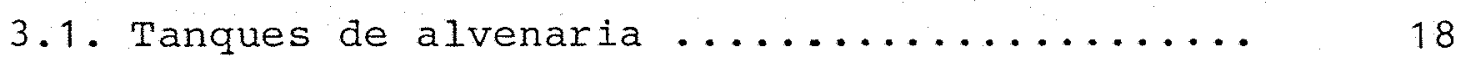

3.2. Solo ........................... 19

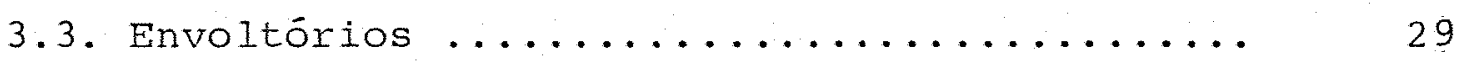

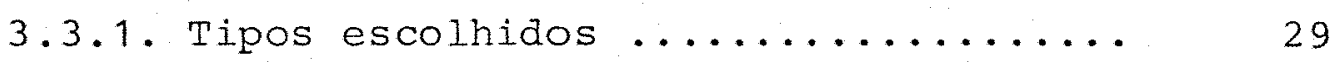

3.3 .2 . Filtro de pedregulho e areia ....... 30

3.3.3. Envelopes de brita ............. 34

3.3.4. Envoltório de geotêxtil ober $851 \ldots 35$

3.3.5. Envoltório de geotêxtil Bidim OP-30... 35

3.4. Delineamento experimental ........... 36

3.5. Procedimentos experimentais ........... 37

3.6. Lâmina Iíquida drenada em duas horas ....... 44

3.6.1. Processo de cálculo ........... 46

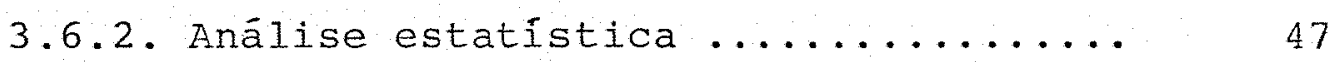

3.7. Lâmina mínima satisfatória ............ 47

3.8. Taxas de carreamento de solo ............ 49

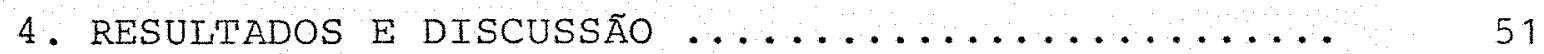

4.1. Efeito dos tratamentos na lâmina liquida dre

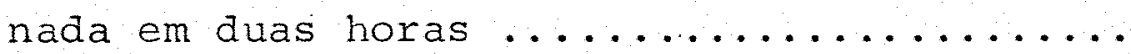

4.2. Curvas de descarga e tempo necessário para dre nagem da lâmina minima satisfatória .......

4.3. Efeito dos tratamentos no carreamento de solo

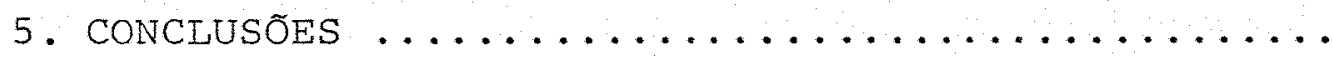


pāgina

6. LITERATURA CITADA ...................... 71

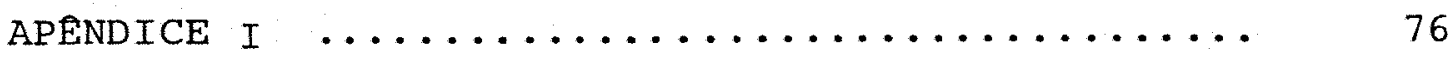

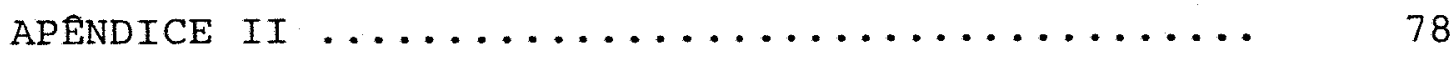




\section{LISTA DE TABELAS}

TABELA NO

Página

01 Determinação da necessidade de filtros e en velopes para drenos, com base no tipo de so-

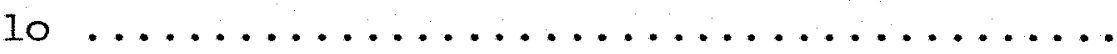

02

Disposição dos tratamentos nos tanques em cada repetição

03 Início das medições de vazão, volume dos repientes utilizados e intervalos de mediçãode

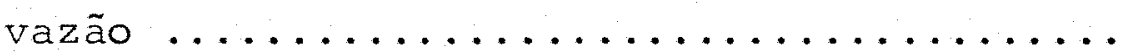

04 Esquema da anālise de variância .........

05 Análise de variāncia das lâminas liquidas dre nadas por metro de tubo em duas horas ...... Valores médios de lâminas liquidas drenadas por metro de tubo em duas horas ..........

07 Taxas médias de carreamento de solo durante a drenagem dos tanques, para todos os tratamentos, expressas em miligramas de areia por

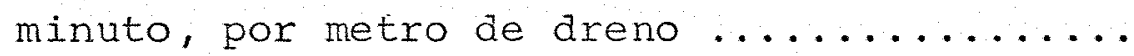


vii.

\section{LISTA DE FIGURAS}

FIGURA NO

Pāgina

$01 \quad$ Ispecto geral conjunto de tanques ..........

02 Planta baixa de um dos tanques...........

03 Corte Iongitudinal de um dos tanques .......

04 Curva granulométrica do solo utilizado no ex-

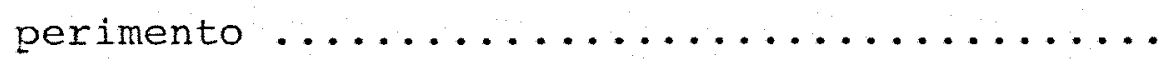

05 Curva granulométrica do filtro de pedregulho

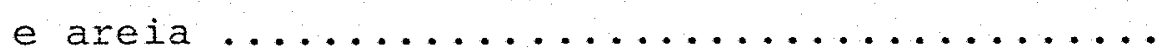

06 Corte de um dos tanques com envoltório de bri

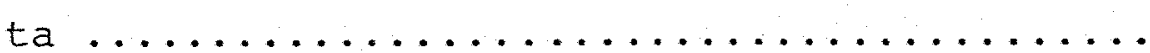

07 Hiảrograma da variação de vazão durante a dre nagem de tanque com dreno envolto por filtro

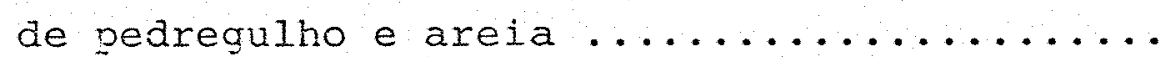

08 Curva de descarga do tanque com dreno envol to

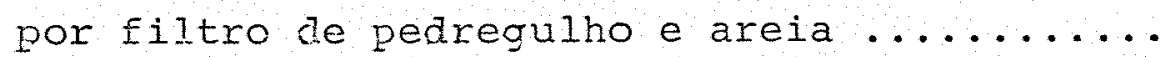

09. Curva de descarga do tanque com dreno envolto por envelope de brita no $1 \mathrm{com} 10 \mathrm{~cm}$ de espes

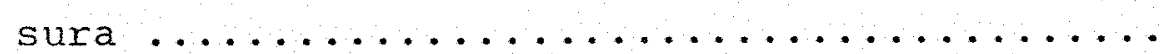

10 Curva de descarga do tanque com dreno envolto por envelope de brita no $1 \mathrm{com} 5 \mathrm{~cm}$ de espes-

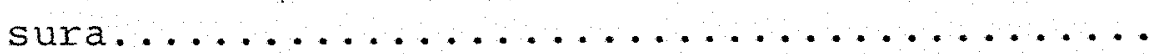


viii.

FIGURA No

Pàgina

11 Curva de descarga do tanque com dreno envolto por envelope de brita no $1 \mathrm{com} 2,5 \mathrm{com}$ de espessura $\ldots \ldots \ldots \ldots \ldots \ldots \ldots \ldots \ldots \ldots \ldots \ldots \ldots \ldots \ldots \ldots \ldots$

12 Curva de descarga do tanque com dreno envolto por geotêxtil ober $851 \ldots \ldots \ldots \ldots \ldots \ldots \ldots \ldots \ldots \ldots \ldots \ldots$

13 Curva de descarga do tanque com dreno envolto por geotêxtil Bidim op $-30 \ldots \ldots \ldots \ldots$

14 Curva de descarga do tanque com dreno sem en-

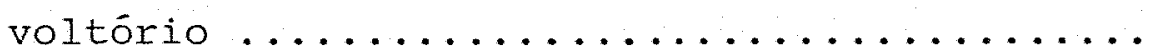




\title{
DESEMPENHO DE ENVOLTÓRIOS NA EFICIENCIA DA DRENAGEM DE UM SOLO COM DRENOS TUBULARES
}

\author{
Autor: ANTONIO AUGUSTO ALVES PEREIRA \\ Orientador: Prof. Dr. DECIO EUGENIO CRUCIANI
}

RESUMO

o uso de envoltórios mais permeáveis que osoIo ao redor de drenos tubulares, melhora as condições de flu xo e reduz o carreamento de particulas de solo para os drenos.

Com o objetivo de avaliar o desempenho de diferentes envoltórios na drenagem de um solo franco arenoso, testou-se em tanques de alvenaria os tratamentos filtro de pedregulho e areia com $10 \mathrm{~cm}$ de espessura, envelopes de brita no 1 com 10 $\mathrm{cm}, 5 \mathrm{~cm}$ e $2,5 \mathrm{~cm}$ de espessura, geotêxteis ober 851 e Bidim OP-30 e ausência de envoltório. Através de sucessivos rebaixamentos do lençol freático, coletou-se dados de vazão e peso de solo carreado, usados na determinação da lámina arenada por metro de tubo em duas horas, tempo para a drenagem de uma lāmina adotada como minima satisfatória e taxas de carreamento de solopor metro de areno em diferentes momentos da drenagem. 
As lâminas drenadas em duas horas por metrode tubo foram: $255,8 \mathrm{~mm}$ para o filtro de pedregulho e areia, 233,3 e 223,9 mm para os envelopes de brita com 5 e $10 \mathrm{~cm}$ de espessura, respectivamente, $221,0 \mathrm{~mm}$ para o geotêxtil Bidim OP-30, 200,5 mm para o envelope de brita de 2,5 cm de espessura, $188,3 \mathrm{~mm}$ para o geotéxtil ober 851 e $164,7 \mathrm{~mm}$ para o tratamento sem envoltório. As três maiores lâminas diferiram estatisticamente ao nível de 5\% de probilidade da lâmina dre nada pelo tratamento sem envoltório. O filtro de pedregulhoe areia diferiu também do geotéxtil ober 851 ao nível de $5 \%$. To dos os demais contrastes entre tratamentos não diferiram estatisticamente ao nivel de $5 \%$

o tempo para a drenagem de $205,5 \mathrm{~mm}$ valor ado tado como o de uma lāmina mínima satistafória, foi de $40 \mathrm{mi-}$ nutos para o filtro de pedregulho e areia, 57 e 83 minutos pa ra os envelopes de brita com 5 e $10 \mathrm{~cm}$ de espessura, respectivamente e 102 minutos para o geotêxtil Bidim op-30. Paraos demais tratamentos, o tempo de drenagem foi superior a duas horas.

Apesar da expectativa de que ocorresse carreamento de particulas em função das caracteristicas do solo es tudado, esta se deu em escala muito pequena nas amostras coletadas, não permitindo distinguir o efeito dos tratamentos.

Analisando somente o aumento conferido à capa cidade de drenagem, o melhor desempenho foi o do filtro de pe 
dregulho e areia. Considerando-se também a facilidade para ob tenção e instalação no campo, concluiu-se que o melhor envol tório foi o geotéxtil Bidim op-30. 
DRAIN TUBES DISCHARGE CAPACITY AND SEDIMENT ENTRANCE AFFECTED BY WRAPPERS.

Author: ANTONIO AUGUSTO ALVES PEREIRA

Adviser: Prof. Dr. DECIO EUGENIO CRUCIANI

\section{SUMMARY}

Permeable wrapper used around subsurface drains improve flow conditions and decrease soil particles movement into drains.

The performance of different wrappers in a sandy loam soil drainage was evaluated, in lisimeters with the treatments: $10 \mathrm{~cm}$ thick sand and gravel filter, $10 \mathrm{~cm}, 5 \mathrm{~cm}$ and $2,5 \mathrm{~cm}$ thick gravel envelopes, non-woven fabrics with trade name Bidim $O P-30$ and ober 851 and drain without wrapper.

During successives drainages in lisimeters, outflow and mass of sediment transported by water were measured and used to determine the height drained per two hours per one metre, the time for drainage of a given height and the rates of soil transport in different times.

Height drained per two hours per one metre 
were: $255.8 \mathrm{~mm}$ for sand and gravel filter; $233.3 \mathrm{~mm}$ and 223.9 $\mathrm{mm}$ for $5 \mathrm{~cm}$ and $10 \mathrm{~cm}$ thick gravel envelope, respectively; 221.0 $\mathrm{mm}$ for Bidim OP-30; $200.5 \mathrm{~mm}$ for $2.5 \mathrm{~cm}$ thick gravel envelope; $188.3 \mathrm{~mm}$ for Ober 851 and $164.7 \mathrm{~mm}$ for drain without wrap per. There was a significant difference (5\% probability) bet ween the firsts three treatments and the drain without wrap per. Sand and gravel filter was significantly different probability) from the ober 851 fabric. All other comparison showed no significance.

Drainage times for the given height of 205.5 $\mathrm{mm}$, were 40 minutes for sand and gravel filter; 57 and $83 \mathrm{mi}$ nutes for $5 \mathrm{~cm}$ and $10 \mathrm{~cm}$ thick gravel envelopes, respectively, and 102 minutes for Bidim OP-30. Drainage time was greather than two hours for all other treatments.

Soil particle movement into drains were expec ted because of soil characteristics; however, the small amounts of soil collected in samples did not allow to identify treat ment effect.

The sand and gravel filter showed the best performance if only increase in arainage capacity is considered. Including instalation suitability and avaiability, geotextile Bidim OP-30 showed the best performance. 


\section{INTRODUÇÃO}

Os drenos tubulares são os mais indicados pa ra os sistemas de controle do lençol freático devido ao seu bom desempenho, longa aurabilidade e pouca necessidade de ma nutenção. Apesar disso há uma série de problemas que comprometem o funcionamento deste tipo de drenos, os quais são agra vados pelo fato deo sistema ser totalmente enterrado no solo, - que dificulta a identificação e o reparo de avarias.

Um dos problemas que ocorre com frequência, causando redução na eficiência do sistema de drenagem, é o entupimento dos drenos por particulas de solo que penetram em seu interior levadas pela água drenada. A maneira usual de evitar a ocorrência deste fenômeno, é a colocação de material de alta permeabilidade entre o solo e o dreno, que tem co mo funções principais impedir o carreamento de particulas e facilitar a entrada à àgua (WILIARDSON, 1974). o uso desses envoltórios associados a arenos tubulares é particularmente 
importante em solos de baixa coesão, em geral constituidos por silte ou areia fina (LUTHIN, 1968).

o presente trabalho teve como objetivo a ava liação do desempenho de alguns materiais usados como envoltó rios de arenos tubulares, analisando-se a eficiência da drenagem, com base no carreamento de solo e na lâmina líquida es coada.

o experimento foi conduzido em tanques pla nejados para reproduzir aproximadamente a geometria e as con dições de instalação de drenos tubulares no campo, sendo o tempo de coleta de dados em cada repetição de 3 a 4 semanas.

Devido ao grande número de materiais recomen dados para a confecção de envoltórios, que podem ser combina dos entre si ou usados com diferentes espessura em torno do areno, e considerando que para cada tipo de solo haverá um envoltório mais adequado tanto no aspecto técnico como noeco nômico, muitas pesquisas deverão ser realizadas para solucio nar os problemas da drenagem agrícola. Espera-se que este trá balho venha a contribuir para tal intento. 
Os sistemas de drenagem subterrânea podem ser constituídos por diferentes tipos de drenos, tais como: canais de terra, drenos tubulares, feixes de bambu e drenos li vres (mole drains). Vários fatores contribuem para a seleção de um tipo de dreno, podendo-se citar como exemplo, a topografia do terreno, as características do solo e o regime plu viométrico (DONNAN e SCHWAB, 1974; MILLAR, 1978).

A opção por drenos tubulares leva a um alto investimento inicial decorrente do seu custo de aquisição e instalação no campo. Por outro lado, pode-se esperar desses drenos maior vida útil, pouca manutenção e quando comparados a canais de terra, maior rendimento nas operações mecanizadas (RAADSMA, 1947). Os tipos mais difundidos são: as maniIhas cerâmicas, os tubos plásticos de p.v.c. ou polietileno e os tubos de concreto (CRUCIANI, 1980). 
Segundo CAVELAARS (1974), em geral é preferí vel o uso de drenos tubulares para a função de alivio, deixando aos canais a função de coletores. BATISTA et alii (1984) afirmam que só nos EEUU há 40 milhões de hectares recuperados por sistemas de drenos tubulares.

Diversos relatos tem sido feitos sobre o colapso ou falha de sistemas de drenos tubulares. De acordo com SUTTON (1952), em uma área de Ohio, EEUU, 165 sistemas constituidos de manilhas cerâmicas precisaram ser recuperados após funcionarem por 30 a 40 anos. As causas que levaram ao co lapso foram: manutenção inadequada ou insuficiente $(28 \%$ dos casos), falhas durante a instalação dos drenos (23\%), projetos mal elaborados (28\%) e má qualidade das manilhas (21\%). o autor cita como causa frequente de problemas, o uso de manilhas de pequeno diâmetro, espaçamento muito grande entre li nhas, entupimento de manilhas por solo ou raizes, desalinhamento e quebra de manilhas, declividade inadequada ou invertida nas linhas de drenos e instalação inađequada em solos arenosos de baixa coesão e solos orgânicos. Outro problema importante é a deposição de óxidos insolúveis de ferro ou manganès nas aberturas dos drenos, o que impede a entrada da àgua (MACKENZIE, 1962; GRASS, 1969).

Dentre os problemas citados, muitos podem ter solução apenas com uma supervisão cuidadosa da instalação das linhas de arenos; outros são resolvidos por processos químicos, como o uso de gás sulfidrico para dissolver as deposi- 
çōes de ōxido de ferro. Com relação ao entupimento de drenos por solo, sabe-se que são dois os aspectos principais a ser solucionados: que solos são mais propensos ao carreamento e qual a forma de evitá-1o.

Segundo GULATI et alii (1970), o carreamento de particulas de solo para o interior de drenos tubulares é mais acentuado em. solos não coesivos, com textura variando desde silte grosso até areia média; os solos coesivos e os de textura grossa bem graduados são resistentes ao carreamen to. GRASS e MACKENZIE (1972) citam apenas o silte como causa comum de entupimento de drenos. LUTHIN (1968) afirma que o pro blema ocorre em solos instáveis constituidos por silte ou areia fina mal estruturada; solos com alta porcentagem de ar gila e matéria orgānica apresentam coesão suficiente para re sistir à quebra dos grandes agregados e impedir o carreamento de particulas individuais. O autor afirma ainda que ocorre a entrada de particulas nos drenos quando se usa água para promover a estabilização do solo usado no preenchimento das valetas, com o que concordam GRASS e MACKENZIE (1972).

VARGAS (1978) explica que por efeito da percolação, surge na água que preencher os poros do solo, em cá da ponto do terreno, uma pressão correspondente à altura em que a áqua subiria num piezómetro colocado neste ponto. Consi derando uma malha quadrangular isolada em um canal de fluxo, compreendida entre duas Iinhas equipotenciais, o autor afirma que da diferença de pressão existente entre as faces de 
entrada e saída da malha resulta uma força que age na direção do fluxo. Essa força dividida pelo volume da malha é a força de percolação por unidade de volume, que é um vetor cuja direação é a da linha de fluxo e o módulo é:

$$
|\vec{p}|=|\vec{i}| \gamma_{0}
$$

onde

$\vec{i}$ é o gradiente hidráulico médio na malha considerada.

$\gamma_{O}$ é o peso específico da āgua.

Segundo LUTHIN (1968), quando um fluxo ascendente emerge do solo, a força de percolação tende a deslocar e elevar particulas. O desarranjo ocasionado na superficiere duz a resistência da massa de solo à subpressão e progressivamente o processo se estende ao sub-solo. A força de percolação, vertical e ascendente, supera o peso da massa de solo fazendo com que as particulas pareçam estar flutuando sem coesão e capacidade de sustentação, resultando a condição cô nhecida por "areia movediça".

A força de percolação não depende da conautividade hidráulica do solo ou da densidade de fluxo e alcança seu maior valor na interface solo-dreno, que é a zona de mai or convergência das Iinha de fluxo e onde ocorrem os gradien tes máximos. A este valor máximo dá-se o nome de gradiente hị drálico de saída.

Denomina-se gradiente critico de ruptura hidráulica o gradiente que dá origem a forças de percolação cạ 
pazes de promover a desagregação e o carreamento de partículas de solo. Se o gradiente de saida atingir o valor do gradiente de ruptura hidráulica haverá carreamento de partículas (SAMANI e WILLARDSON, 1981).

Segundo BATISTA (1980), o gradiente de ruptura hidráulica está diretamente relacionado com o indice de plasticidade e a densidade global de um determinado solo. Em outras palavras, solos de textura fina e solos adensados ofe recem maior resistência às forças de percolação.

Nos casos em que o solo drenado tem pouca resistência ao arraste de partículas, recomenda-se a colocação de envoltórios ao redor dos drenos tubulares. Esses envoltórios de drenos são também conhecidos por envelopes ou filtros e são confeccionados com material orgânico como fibra de coco, palha, serragem, sabugo de milho e turfa ou com material inorgânico como areia, pedra britada, pedregulho, fibra de vidro, geomembranas de poliéster ou polipropileno, além de outros materiais (BATISTA, 1983).

Segundo HOLANDA (1984), nos primeiros projetos de drenagem subterrânea executados na Europa, os tubos de drenagem eram cobertos com uma camada de material orgānico a fim de facilitar o fluxo de água para as tubulações e evitar que particulas de solo penetrassem nos tubos entupindo-os. Po rém, a colocação desses materiais era muito trabalhosa e nem sempre havia disponibilidade de quantidade necessária. Com a 
progressiva mecanização das operações de drenagem pesquisouse novos materiais que pudessem ser produzidos em forma de faixa, começando com materiais tradicionais como flocos de turfa, palha de linho, fibra de coco, evoluindo mais tarde para folhas finas de fibra de vidro e com tendència atual pa ra uso de tecidos de fibra sintética. Este último material tem se mostrado particularmente apropriado para uso nas máquinas de instalação de tubos.

Segundo WILLARDSON (1984), o emprego de envol tórios é importante por proporcionar uma base adequada para o assentamento dos arenos, auxiliar a estabilização do solo empregado para preencher as valetas, prover a zona vizinha às aberturas dos drenos de material mais permeável que o solo circundante e impedir o carreamento das particulas do solo que podem se depositar e obstruir os drenos.

Há na literatura consultada relatos discordantes quanto à função que devem exercer os envoltórios e os materiais mais apropriados para sua confecção. As principais divergências referem-se à espessura do envoltório em torno dos drenos e se a forma de atuação deve ser aquela exercida por uma filtro. Esta é também a razão para a existência de dois termos para designar os envoltórios: filtros e envelopes.

PIZARRO (1975) comenta a necessidade de impe dir o carreamento de partículas de solo, e ao mesmo tempo au mentar a permeabilidade da zona junto às aberturas do dreno. 
Para o autor, essa ação simultānea exigiria do material sele cionado características opostas: para impedir o carreamento - material escolhido deveria ter textura fina e poros pequenos, mas para aumentar a permeabilidade seria necessário material de textura grossa.

Pela definição do Soil Conservation Service (EEUU, 1971), filtro é o material permeável colocado ao redor de um areno com o propósito de impedir a entrada de partículas finas do solo adjacente. Como envelope, os autores de finem o material permeável colocado ao redor de um dreno com - propósito de melhorar as condições de fluxo na área circun dante e também de facilitar o assentamento de tubos ou maniIhas. Os autores sugerem um roteiro para determinação da necessidade de filtro ou envelope com base no tipo de solo a ser drenado (Tabela 1) e estabelecem critérios para seleção dos materiais usados na confecção dos envoltórios.

WILLARDSON (1974) afirma que a função de um filtro é reter particulas em suspensão num fluido e por isso sua permeabilidade diminui com o tempo, tendendo ao entupimento. Por outro lado, deve-se colocar material de textura grossa ao redor dos drenos para auxiliar a estabilização mecânica e hidráulica do solo, sendo essa a função de um envelope. 
BATISTA (1983) apresenta uma definição mais completa de envelope ao considerar as condições que geram a desagregação e o movimento de partículas. Segundo o autor, en velope é todo o material colocado entre um dreno tubular e o solo, que por ser de condutividade hidráulica bastante maior que aquela da camada de solo próxima do dreno, propicia uma redução do gradiente hidráulico nas proximidades deste, oque em consequéncia resulta em baixa velocidade de fluxo nos poros do solo. Essa redução de velocidade de fluxo da ägua na interface solo-envelope e suas proximidades faz com que o car reamento de particulas para o interior do dreno seja pequeno ou praticamente nulo. Baseado nesse conceito, o autor afirma que se a redução do gradiente hiaráulico de saida propiciada pelo envoltörio for suficiente para torná-lo menor que o gra diente de ruptura hidráulica do solo, não ocorrerá carreamen to de particulas. Conclui também que, para solos com baixo gradiente critico de ruptura hidráulica, a espessura do enve lope deverá ser maior.

Estas conclusões concordam com os resultados obtidos por WESSELING e HOMMA (1967), ao estudarem a resistência a entrada de água ofereciaa por um tubo perfurado com $4 \mathrm{~cm}$ de diâmetro instalado em um lisimetro. Cinco tratamentos foram testados, sendo o de menor espessura o dreno sem envoltório seguido por uma camada de fibra de vidro envolven do o dreno, duas camadas de fibra de vidro, cinco camadas de Eibra de viaro e $1 \mathrm{~cm}$ de 1 á de viaro. Constatou-se que a re- 
sisténcia à entrada de água decresceu com o aumento da espes sura dos envoltórios.

SAMANI e WILLARDSON (1981) deduziram uma equa ção para estimar o gradiente crítico de ruptura hidráulica de solos dos EEUU, com base na condutividade hidráulica em condições de saturação e indice de plasticidade. Através de exem plo mostraram a possibilidade de calcular a espessura adequa da para envelopes, sem adotar porém qualquer critério referente à condutividade hidráulica do material.

Quanto aos materiais orgānicos usados na con feccão de envoltórios, sabe-se que tem largo emprego em regióes de clima temperado, onde as condições para oxiáaçãonão são intensas. Sua qualidade varia também com a distribuição do tamanho das particulas que compõe o material. Brownscombe (citado por WILIARDSON, 1974) relata inspeção feita em siste mas de drenagem no Canadá, onde usou-se palha e lascas da ma deira como envoltório. A palha mostrou-se eficiente no controle do carreamento de particulas e sofreu decomposição moderada após 11 anos no solo. Observou-se o desenvolvimento de buracos na palha situada abaixo dos tubos, o que poderia pro vocar desalinhamento em solos menos estáveis. As lascas de madeira sofreram somente uma pequena deterioraça após 9 anos dentro do solo. O autor recomenda o uso de $15 \mathrm{~cm}$ de naterial solto, para que, após a compressão sofrida durante o f́cha- 
mento da valeta, obtenha-se um envoltório de no mínimo $8 \mathrm{~cm}$ de espessura.

Segundo SERAPHIM (1982), a partir de 1967 sur giram no mercado mantas sintéticas fabricadas a partir de fi bras e filamentos de poliamida, polipropileno e poliéster, que receberam a denominação de geotéxteis não tecidos. o material assemelha-se a um feltro e tem sido usado como envoltório, sozinho ou associado a material granular.

SILVA (1983) afirma que a presença do geotêx til possibilita a auto formação de uma zona permeável entre - solo e o dreno. Por ser um elemento continuo, formado por um emaranhado aleatório de filamentos, o geotéxtil seleciona as particulas de solo retidas na sua superficie. No inicio do processo, as particulas finas atravessam o geotēxtil levadas pela água drenada, permanecendo as particulas grossas, o que ocasiona a formação de una camada mais permeável que o solo. Isto pode ser constatado após a estabilização do processo pe la alteração do indice de vazios na camada citada. o autor cita ainda alguns fatores favoráveis aos geotêxteis, tais co mo: ser imputresciveis, apresentar alta permeabilidade (da ordem de $0,1 \mathrm{~cm} / \mathrm{s})$, dispensar cálculos granulométricos neces sários aos filtros de areia e ser de fácil colocação ao re- 
dor do dreno, exigindo menos mão-de-obra que a instalação de materiais granulares.

Os tubos plásticos flexíveis podem ser encapados facilmente com uma "camisa" de geotêxtil previamente pre parađa na indústria. Em regiões onđe não há material granular próximo da área a ser drenada, o geotêxtil é uma boa opção, pois seu reduzido peso facilita o transporte além da vantagem de poder ser obtido em qualquer quantidade, o que torna seu uso bastante cômodo.

SILVA (1983) relata que a partir de 1977 desenvolveram-se as chamadas "mantas de segunda geração" ou "man tas hibridas", que se caracterizam por apresentar duas ou três camadas de permeabilidade distinta superpostas. Geralmente apresentam uma camada formada por fibras grossas (poro metria grandel, destinada a satisfazer os requisitos de boa drenabilidade e filtrabilidade, e uma ou duas camadas de fibras finas (porometria menor), destinadas a atuar como barreira anti-contaminação ou anti-colmatação. Segundo o autor, para o evelopamento de tubos de drenagem, a manta com estratificação porométrica dupla seria a mais indica, deixando-se a face anti-contaminante em contato com o solo para impedir - carreamento de particulas. 
Hā na literatura referências sobre outros ti pos de materais sintéticos aplicáveis a sistemas de drenagem, como os véus de fibra de vidro ou nylon e as calhas de lá de vidro rígidas. Sua aceitação no entanto não é grande pelos problemas que apresentam. As calhas de fibra de vidro rigidas podem sofrer quebras e amolgamentos durante o transporte e manuseio, além de provocarem alexgia e dermatites em certas pessoas após contato prolongado. Os véus não permitem o apro veitamento da componente horizontal do fluxo devido a sua re duzida espessura, além de estarem sujeitas à ocorréncia de colmatação química por precipitação de sais de ferro (véu de fibra de vidro) e bloqueio por partículas finas (WILLARDSON, $1974 ;$ SILVA, 19831 .

Diversas pesquisas tem sido feitas com o objetivo de analisar o desempenho dos diferentes envoltórios disponiveis. O principal aspecto enfocado tem sido a necessi dade do uso de envoltório em solos de baixa coesão, visando incrementar a vazão e impedir o carreamento de partículas do solo para o interior dos drenos. Os experimentos relatados apresentam-se muitas vezes bastante especificos para condições locais, o que impede extrapolação de resultados. Sua aná lise é, no entanto, muito importante em países onde não há tradição no emprego de drenos tubulares, pois permite a iden tificação de linhas gerais de conduta.

DAVIS et alii (1971) estudaram a vazão de ma nilha cerâmica, de dreno de concreto e de dreno plástico cor 
rugado com envoltório de brita, areia natural e areia isenta de particulas finas, totalizando nove combinações que foram testadas em duas repetiçoes em solo arenoso. Foram testadas sem repetição, manilha cerêmica e areno de concreto sem envoltório, dreno de concreto envolto por areia com partículas finas, dreno plástico envolto com uma capa proposta por WILLARDSON et alii (1968) para controlar a velocidade de entrada da ăgua nos arenos, areno de concreto com a mesma capa, mani Tha cerāmica envolta por filtro de cascalho e areia, e areno de concreto envolto por pedregulhos com $3,1 \mathrm{~mm}$ de diámetro. As menores vazões registradas foram as dos drenos instalados sem envoltório e com a capa para controle de velociade de entrada da água. Todas as demais combinações funcionaram satisfatoriamente.

WILLARDSON et alii (1975) trabalhando em solo franco arenoso, testaram o desempenho de dois tipos de en voltórios de $7,5 \mathrm{~cm}$ de espessura em drenos de concreto. Opri meiro envoltório foi confeccionado com areia natural pura e - segundo com areia acrescida de 5\% de solo. Testou-se também três forams de estabilização do solo colocado nas valetas: inundacão do solo com a saída da linha de drenos fechada, inundação com saida da linha aberta e aspersão com a saída da linha fechada. Os resultados de vazão e altura do lençol freático mostraram que os drenos instalados com envoltóriode areia pura tiveram desempenho nitidamente superior. As diferentes formas de aplicar água para auxiliar a estabilização 
do solo não provocaram efeito relevante.

AL-SOUFI (1981) propôs o emprego de envoltório confecionado com agregados de solo com 2 a $12,25 \mathrm{~mm}$ de diâmetro, recobertos com emulsão de betume. Foram instalados em um lisimetro dois drenos tubulares de $40 \mathrm{~mm}$ de diâmetro, um envolto por $10 \mathrm{~cm}$ de brita e o outro por $10 \mathrm{~cm}$ de agregados cobertos com betume. O solo colocado no lisimetro foi fran co siltoso. Após 90 dias sob carga hidráulica de $30 \mathrm{~cm}$, os resultados mostraram que a vazão produzida pelo dreno envolto com os agregados recobertos por betume foi três vezes maior que a do outro tratamento, indicando a estabilidade a a alta permeabilidade do material testado.

BROUGHTON et alii (1982) realizaram experimento a campo em solo franco arenoso, testando os seguintes tratamentos: dreno corrugado de $100 \mathrm{~mm}$ de diâmetro e $54 \mathrm{~cm}^{2} /$ $m$ de área aberta envolto com geotéxteis de 20,27 e $119 \mathrm{~g} / \mathrm{m}^{2}$, envolto com tela de nylon e sem envoltório; dreno de $80 \mathrm{~mm}$ de diâmetro envolto por brita e areno corrugado de $100 \mathrm{~mm}$ de diāmetro com área aberta de $33 \mathrm{~cm}^{2} / \mathrm{m}$ sem envoltório. Após 4 anos de avaliação, os autores concluiram que os envoltórios de brita, tela de nylon e geotéxtil de $119 \mathrm{~g} / \mathrm{m}^{2}$ possibilitaram as maiores taxas de drenagem e a menor entrada de sedimentos nos drenos. Os drenos instalados sem envoltório enche ram-se de areia fina e os geotéxteis de menor gramatura sofreram muitos danos por abrasão. 
BATISTA et alii (1984), em experimento feito a campo, testaram dois envoltórios, sendo o primeiro de brita com $10 \mathrm{~cm}$ de espessura em toda a volta do dreno e o outro de geotêxtil BIDIM OP-20 envolvendo dreno e brita, com esta colocada apenas na parte inferior do tubo. Trinta e seis poços de observação foram instalados para acompanhar a oscilação do lençol freático. Os resultados obtidos mostraram que - comportamento dos dois tratamentos testados foi semelhante. 
18.

\section{MATERIAL E METODOS}

\subsection{Tanques de alvenaria}

o experimento foi instalado no centro deciên cias Agrárias da Universidade Federal de Santa Catarina, em Florianópolis, estado de Santa Catarina.

Construiu-se no local sete tanques de alvenaria, com revestimento interno de argamassa e de impermea bilizantes a base de silicone. As paredes foram erguidas sobre uma base de concreto, ficando cada unidade com $1,5 \mathrm{~m}$ de altura, 1,0 m de comprimento e $0,8 \mathrm{~m}$ de largura, medidos na parte interna.

No interior de cada tanque foi instalado um dreno tubular, com saida provida de tampa na parede frontal. O dreno ficou a $0,4 \mathrm{~m}$ de cada parede lateral e a $0,4 \mathrm{~m}$ acima do fundo do tanque. Duas entradas de água foram colocadas junto ao fundo da parede frontal, ambas ligadas a um 
registro que permitia o enchimento individual de cada tanque com água da rede urbana. Nas figuras 1,2 e 3 estão representados os tanques com suas caracteristicas e dimensões.

o dreno utilizado foi de p.v.c. rígido corru gado marca "Tigre", com 50 mm de diāmetro interno e perfurações cirulares de $4,5 \mathrm{~mm}$ de diâmetro em toda a sua extensão. 0 tubo comercial de $6 \mathrm{~m}$ de comprimento foi cortado em pedaços de $1,2 \mathrm{~m}$ para a colocação nos tanques. A parte útil para drenagem ficou com 1,0 m de comprimento, 156 perfurações e $24,8 \mathrm{~cm}^{2}$ de de área aberta, aproximadamente. A colocação dos tubos foi feita de modo a permitir a entrada de água somente através dos orifícios do dreno, vedando-se bem as extremidades.

o espaço interno do tanque foi destinado à colocação de solo e de um envoltório ao redor do tubo de drenagem. A estrutura foi planejada para permitir a saturação do solo por fluxo ascenđente e a formação de uma coluna de água de $1,1 \mathrm{~m}$ sobre o dreno. Este valor está compreendido dentro dos limite normais de instalação de drenos tubulares no campo.

\subsection{Solo}

o solo utilizado no experimento foi coletado no mangue do rio Itacorubi, em Florianópolis, sendo classificado como solo Aluvial Distrófico. A escolha se deu em fun- 
cão de ser este um solo bastante representativo na região li torânea do estado de Santa Catarina.

A coleta foi realizada na camada de 0 a $20 \mathrm{~cm}$ de profundidade, devido à homogeneidade do solo aí presente, que apresentou textura franco arenosa e auséncia de estrutura (grãos simples). A figura 4 apresenta a curva granulométrica do material coletado, onde se nota a predominância da fração areia e a boa gradação de partículas pela presença de todas as frações granulométricas. As proporções relativas foram: $6 \%$ de pedregulho, $44 \%$ de areia grossa, $30 \%$ de areia fina, $2 \%$ de silte de $18 \%$ de argila. A densidade do solo no campo foi 1,52 $\mathrm{g} / \mathrm{cm}^{3}$ e a densidade de particulas $2,65 \mathrm{~g} / \mathrm{cm}^{3}$.

Com a colocação do solo coletado nos tanques, obteve-se um material que segundo a Classificação Unificada dos Solos (VARGAS, 1978), pertence ao tipo SC. O apêndice I apresenta a Classificação Unificada dos Solos.

A Tabela 1 apresenta recomendações sobre a necessidade de filtro ou envelope, com base nos tipos de so10 definidos pela Classificação Unificada. Observando-se are ferida tabela, nota-se que os solos foram divididos em três grupos: o primeiro onde os solos relacionados requerem a pro teção de um filtro, o segundo onde o filtro é opcional e o terceiro, onde os solos não necessitam filtro. o solo selecionado para o experimento, classificado como SC, pertence ao segundo grupo da Tabela 1, ou seja, há uma expectativa de que possa ocorrer carreamento de partículas para o dreno na au sência de filtro ou envelope. 


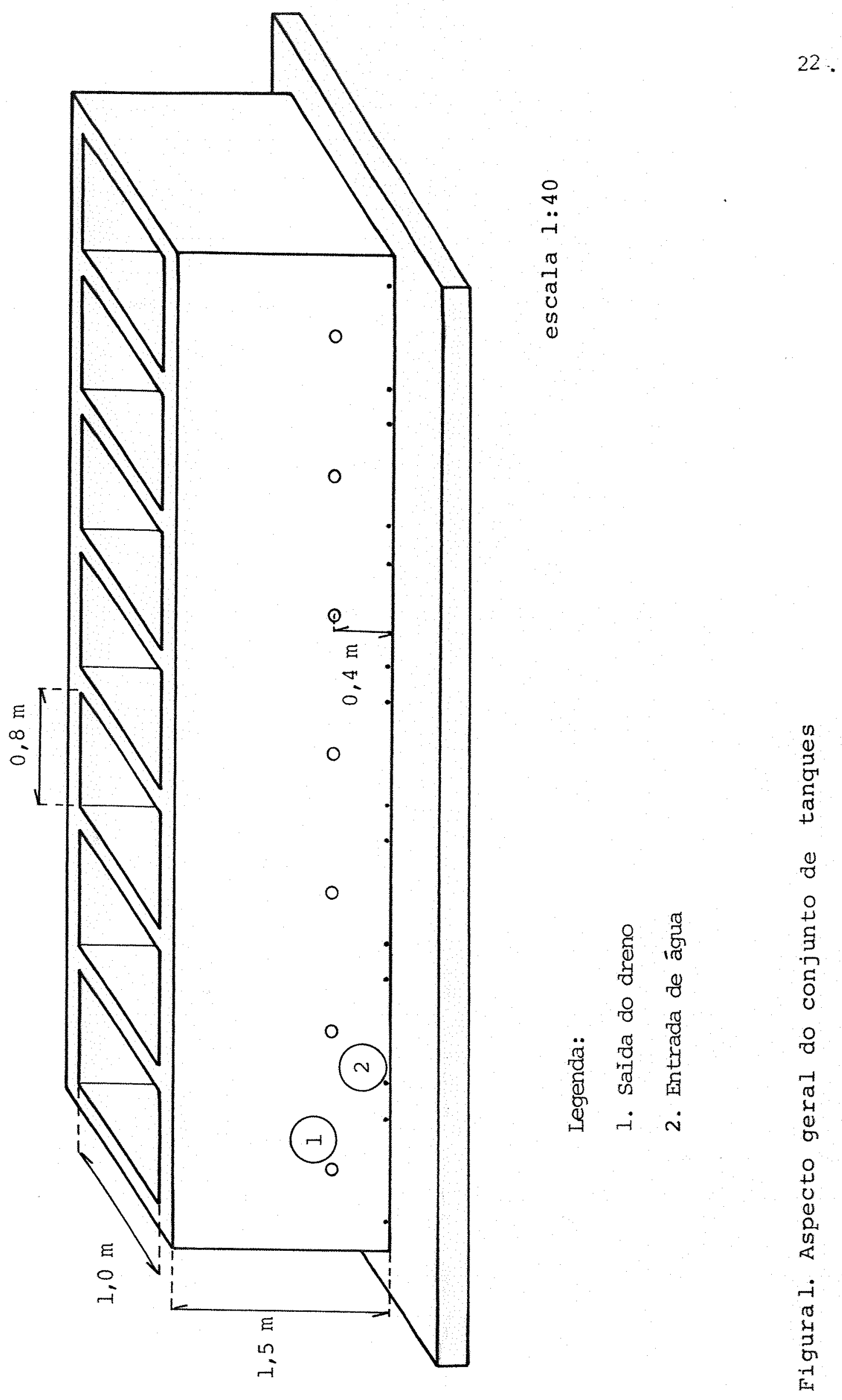




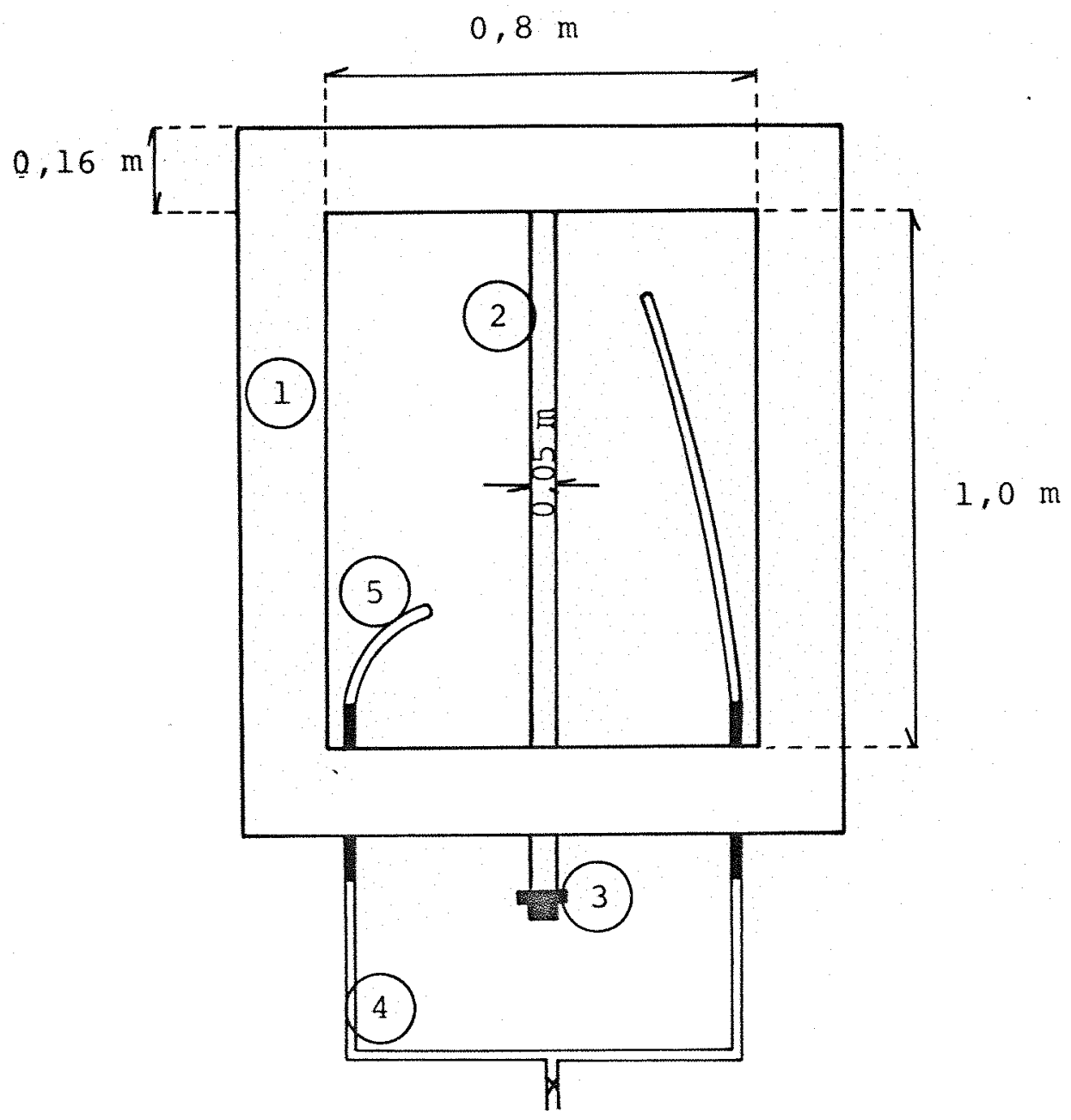

escala $1: 16$

Legenda:

1. Parede do tanque

2. Tubo de drenagem

3. Saída do tubo de drenagem e tampa

4. Sistema de fornecimento de água

5. Mangueira para distribuição da áqua no fundo do tanque Figura 2. Planta baixa de um dos tanques 


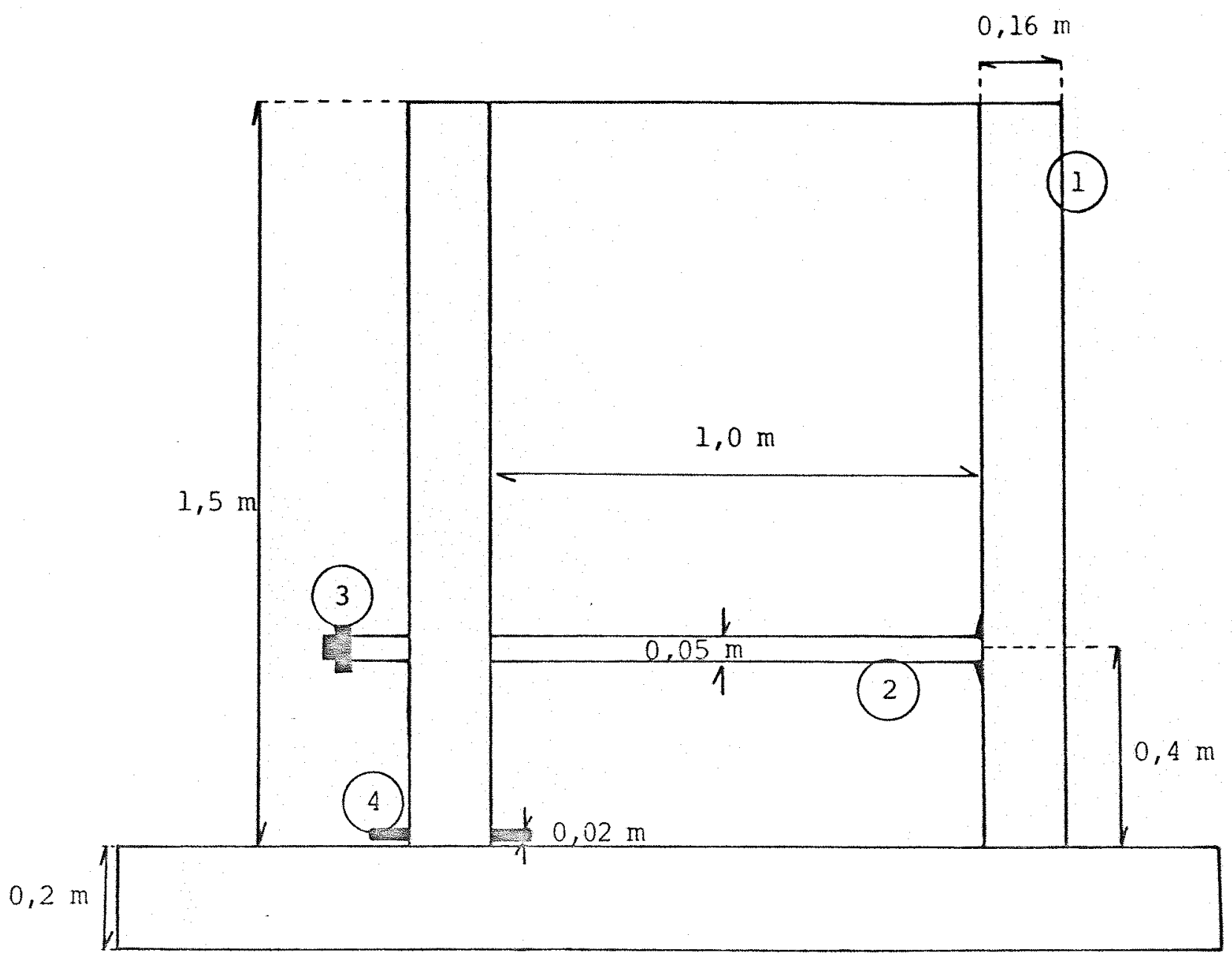

escala $1: 15$

Legenda:

1. Parede do tanque

2. Tubo de drenagem

3. Tampa da saida do tubo de drenagem

4. Tubo de entrada de àgua

Eigura 3. Corte longitudinal de um dos tanques 


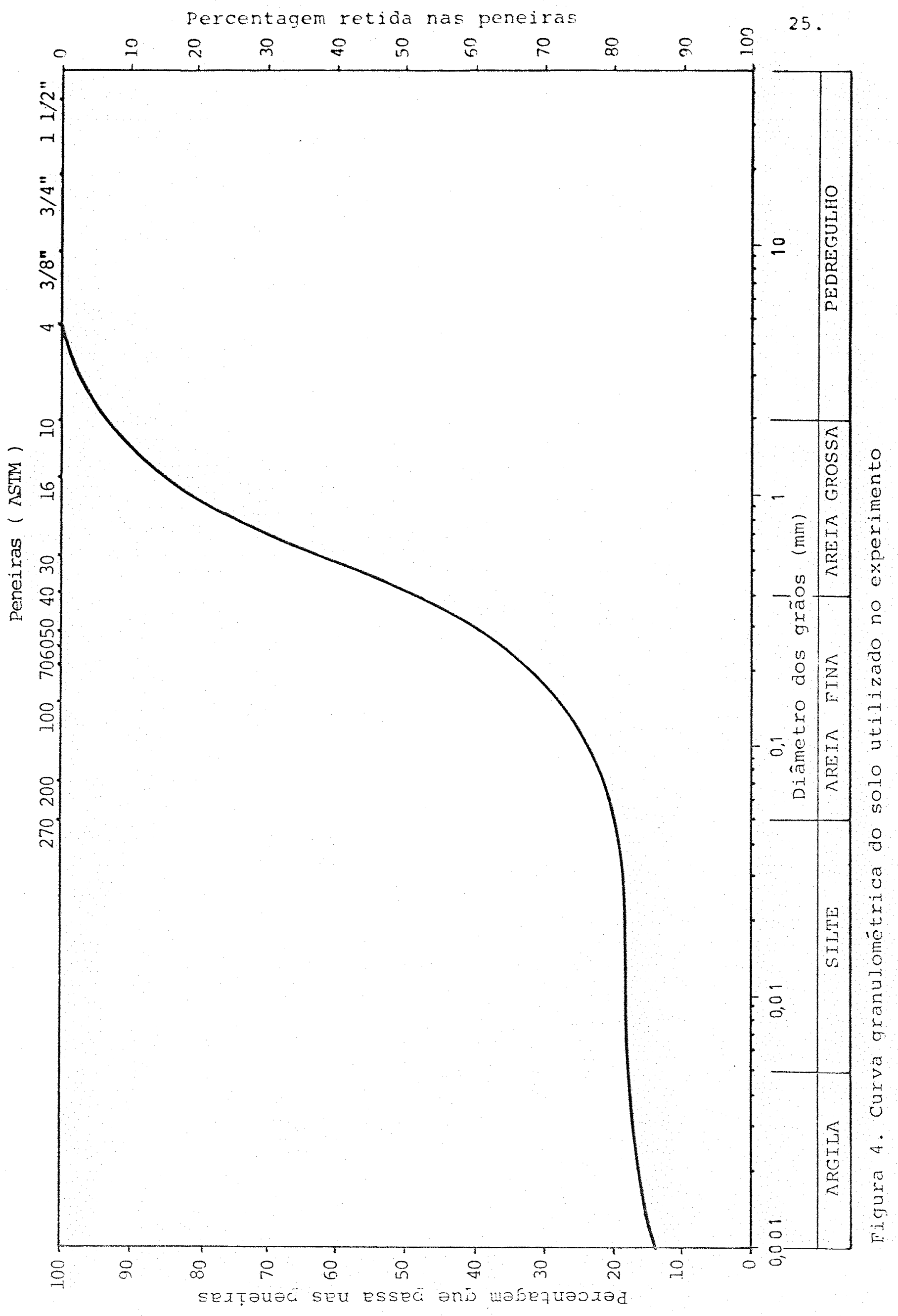


Tabela 1. Determinação da necessidade de filtros e envelopes para drenos, com base no tipo de solo.

Classificação

Unificada dos

Solos
Primeiro Grupo de Solos

- Descrição -
SP (fino)

SM (fino)

ML

MH

Areias com má gradação, areias pedregulhosas

Areias siltosas, misturas de areia e silte com má gradação

Siltes inorgānicos e areias muito finas, alteração de rocha, areias finas siltosas ou argilosas com pequena plasticidade

Siltes inorgānicos, areia fina, solos siltosos micáceos ou diatomáceos, siltes elás ticos

Considerações:

Filtro

Envelope

Vel. da água
Sempre necessário

Desnecessário quando se usar filtro de pedregulho e areia, mas recomendável com dre nos tubulares flexiveis associados a outro tipo de filtro

Nenhuma recomendação 
Tabela 1. Continuaçāo

Classificação

Unificada dos

Solos
Segundo Grupo de Solos

- Descrição -
GP

$\mathrm{SC}$

GM

SM (grosso)

Considerações:

Filtro

Envelope

Vel. da àgua
Pedregulhos com má gradação, misturas de cascalho e areia com pouco ou nenhum fino Areias argilosas, misturas de areia e argi la com má gradação.

Pedregulhos siltosos, misturas de pedreguIho, areia e silte com má gradação

Areias siltosas, misturas de areia e silte com má gradação

Decisão de uso condicionada ao exame das condições locais

Desnecessário quando se usar filtro de pedregulho e areia, mas recomendável com dre nos tubulares flexiveis associados a outro tipo de filtro

Com uso de filtro, nenhuma recomendação; sem filtro velocidade minima de $0,43 \mathrm{~m} / \mathrm{s}$ 
Tabela 1. Continuação

Classificação
Unificada dos
Solos

GC

Pedregulhos argilosos, misturas de pedregu Tho, areia e argila com má gradação

CL Argilas inorgānicas de baixa e média plasticidade, argilas pedregulhosas, argilas arenosas e argilas siltosas

SP, GP (grosso) Iguais aos solos SP e GP já citados

GW

Pedregulhos com boa gradação, misturas de areia e pedregulho com pouco ou nenhum fino SW Areias com boa gradação, areias pedregulho sas com pouco ou nenhum fino

$\mathrm{CH}$ Argilas inorgānicas de alta plasticidade

OL

$\mathrm{OH}$
$\mathrm{Pt}$
Considerações: Siltes orgânicos e siltes argilosos orgâni cos de baixa plasticidade

Filtro

Desnecessário

Envelope

Argilas orgânicas de média e alta plastici dade

Solos com elevado teor de matéria orgānica opcional. Pode ser necessário com dreno tú bular flexivel

Vel. da ãqua Nenhuma recomendação para solos com pouco ou nenhum fino. para solos com finos velocida da minima de $0,43 \mathrm{~m} / \mathrm{s}$

Fonte: EEUU U.S. Departament of agriculture. Soil Conservation Service, 1971. Drainge for Agricultural Lands. Port Washington. 460 p. 


\subsection{Envoltórios}

\subsubsection{Tipos escolhidos}

Foram escolhidos para o experimento três tipos de envoltório de grande aceitação e de largo emprego, que deram origem a sete tratamentos.

o primeiro tipo escolhido foi o filtro de pe aregulho e areia recomendado pelo soil conservation service (EEUU, 1971), para o qual há especificações tanto de espes sura como de gradação de partículas. Sua concepção está baseada no conceito de um filtro, devendo portanto reter partí culas de solo carreadas pela água percolada.

o segundo tipo de envoltório, que deu origem a três tratamentos, foi baseado no conceito de envelope, ou seja, sua habilidade de impedir o carreamento deve-se à redu ção do gradiente hidráulico na zona próxima ao dreno em função da espessura e da alta conđutibilidade hidráulica do material. Não há qualquer recomenđação quanto a gradação de par tículas.

o terceiro tipo de envoltório, que deu origem a dois tratamentos, é o geotéxtil não tecido, que difere dos tipos anteriores por apresentar espessura muito fina ( $3 \mathrm{~mm}$ ) e ser feito de material sintético. Finalmente, para propiciar um maior contraste entre os três tipos citados, foi inclui- 
do um tratamento que consistiu de um dreno tubular sem nenhum envoltório.

Nos itens 3.3.2. a 3.3.5. apresenta-se conde talhes as características dos materiais empregados na confec ção dos sete tratamentos.

\subsubsection{Filtro de pedregulho e areia}

O material empregado na confecção do filtro de pedregulho e areia consistiu de particulas minerais de di ferentes dimensões, em proporções calculadas a partir de sete recomendações elaboradas pelo soil conservation Service. (EEUU, 1971).

1 - Valor máximo para D50(*) filtro $=$ D50 solo $\mathrm{x} 58$ Valor minimo para D50 filtro = D50 solo $\mathrm{x} 12$

Na curva granulométrica do solo, representada na Figura 5, encontrou-se $D 50$ solo $=0,44 \mathrm{~mm}$. Isto indica que a metade das particulas do solo selecionado possui diâme tro menor que $0,44 \mathrm{~mm}$.

D50 filtro máximo $=0,44 \mathrm{~mm} \times 58=26 \mathrm{~mm}$

D50 filtro minimo $=0,44 \mathrm{~mm} \times 12=5,3 \mathrm{~mm}$

${ }^{(*)}$ O valor numérico Dn, expresso em milímetros, indica que no das particulas de um solo possui diâmetro menor ou igual a este valor. 
Portanto: $5,3 \mathrm{~mm}<D 50$ filtro $<26 \mathrm{~mm}$

2 - Valor máximo para D15 filtro $=$ D15 × 40

Valor mínimo para D15 filtro = D $15 \times 12$

$\mathrm{Na}$ figura 5 encontrou-se D15 solo $=0,0017 \mathrm{~mm}$.

Isto indica que $15 \%$ das particulas do solo coletado possui điámetro menor que $0,0017 \mathrm{~mm}$.

D15 filtro mäximo $=0,0017 \mathrm{~mm} \mathrm{x} 40=0,068 \mathrm{~mm}$

D15 filtro minimo $=0,0017 \mathrm{~mm} \times 12=0,020 \mathrm{~mm}$

Portanto: $0,020 \mathrm{~mm}<D 15$ filtro $<0,068 \mathrm{~mm}$

De posse desses resultados foi possivel traçar na figura 5 o intervalo onde deveria estar a curva granu lométrica do filtro. Iste intervalo está representado à direita da curva granulométrica do solo porque as partículas do filtro devem ter diâmetro maior que as do solo. os limites do intervalo foram traçados de modo a ficar aproximadamente paralelos à curva granulométrica do solo, sendo que o limite inferior passou sobre os valores mínimos de D15 e D50 filtro e o limite superior passou sobre os valores máximos de D15 e D50 filtro.

3- D15 filtro máximo $*$ D85 <5

Na figura 5 encontrou-se D85 solo $=1,25 \mathrm{~mm}$. Isto indica que $85 \%$ das particulas do solo selecionado possui diâmetro menor que $1,25 \mathrm{~mm}$.

D15 filtro máximo $=0,068 \mathrm{~mm}$

$0,068 \mathrm{~mm} \div 1,25 \mathrm{~mm}=0,054<5$ (especificação atendida) 
Segundo os autores, valores menores que 5 as seguram a estabilidade do filtro.

4 - D100 filtro $<38,1 \mathrm{~mm}(1,5$ polegada $)$

A especificação pede que não haja no filtro particulas de diámetro maior que $38,1 \mathrm{~mm}$. Para atendê-lo tra çou-se na Figura 5 uma linha pontilhada na vertical represen tativa do diámetro $38,1 \mathrm{~mm}$. A curva granulométrica do filtro ficou restrita ao lado esquerdo da linha pontilhada.

5 - D90 filtro $<19,1 \mathrm{~mm}(3 / 4$ polegada)

A especificação pede que $90 \%$ das particulas tenha diámetro menor que $19,1 \mathrm{~mm}$. Marcou-se na Figura 5 um ponto na interseça da horizontal D90 com a vertical 19,1 mm. A curva granulométrica do filtro passou sobre este ponto para que fosse atendida a especificação.

As especificações 4 e 5 restringiram o tamanho máximo das particulas do filtro, visando evitar avarias nos tubos ou desalinhamento, além de prevenir a excessiva se gregação de particulas durante sua disposição ao redor do dre no.

$6-$ D10 filtro $>=0,25 \mathrm{~mm}$

Esta especificação pede que não mais de $10 \%$ das particulas do filtro, tenha diametro menor que $0,25 \mathrm{~mm}$. Verificou-se aí uma discordāncia com a especificação no 2, que estabeleceu para D15 filtro o valor máxi 

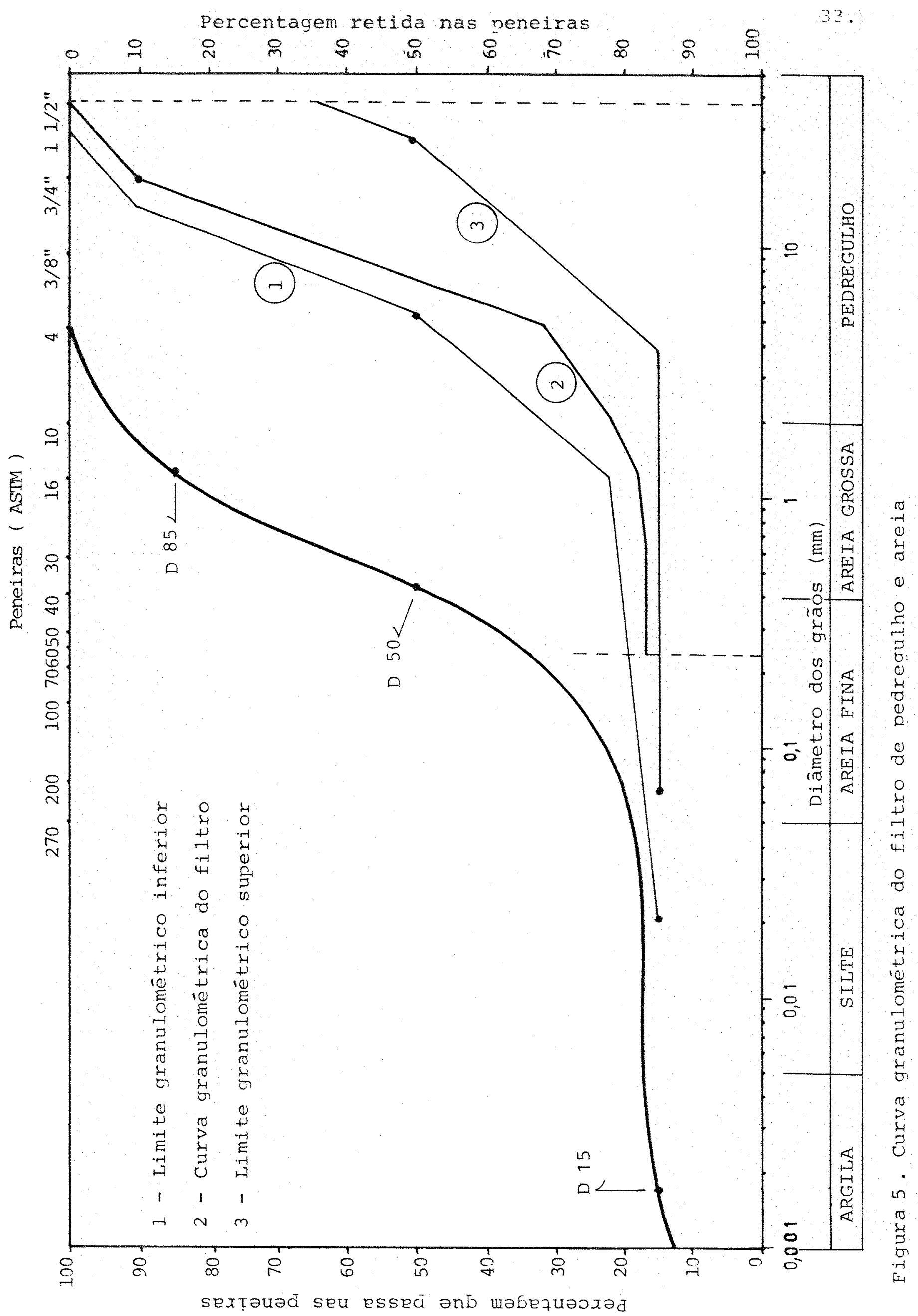
mo de $0,068 \mathrm{~mm}$. Na impossibilidade de se atender às duas especificações, optou-se pela de no 6 , cuja função é de evitar o excesso departiculas finas no filtro, que são facilmente car readas pela água drenada. Para atender a especificação no 6 , traçou-se uma linha pontilhada na vertical representativa do diâmetro $0,25 \mathrm{~mm}$. A curva granulométrica do filtro ficou res trita ao lado direito da linha pontilhada.

7 - A última especificação recomenda que a espessura do filtro seja maior ou igual a $7,62 \mathrm{~cm}$ ( 3 polegadas). Adotou- se no experimento a espessura de $10 \mathrm{~cm}$.

Após a obtenção do intervalo que deveria con ter a curva granulométrica do filtro, passou-se à confecção do mesmo. Face à inexistência de material natural com as caracteristicas exigidas, o filtro foi composto a partir de di ferentes materiais que foram peneirados e misturados. A curva granulométrica do filtro obtido encontra-se representada na Figura 5.

\subsubsection{Envelopes de brita}

Para a confecção dos envelopes de brita empregou-se brita no 1, cujo diāmetro varia entre 1,0 e $2,0 \mathrm{~cm}$ A gradação do material não foi relevante por não se tratarde filtro.

A recomendação para espessura desse envelope 
varia entre 8 e $10 \mathrm{~cm}$ (EEUU, 1971; WILLARDSON, 1974). ReSOI veu-se com base nesse valor adotar 3 tratamentos diferentes: 10,5 e $2,5 \mathrm{~cm}$ de espessura. o objetivo foi o de tentar iden tificar alterações no desempenho, em função da variação da zo na de alta permeabilidade ao redor do areno.

\subsubsection{Envoltório de geotêxtil ober-851}

o geotéxtil não tecido ober-851 é uma manta sintética confeccionada com fibras de polipropileno, cuja densidade superficial é de $300 \mathrm{~g} / \mathrm{m}^{2}$. Sua espessura é de apró ximadamente $3 \mathrm{~mm}$ e a condutividade hidráulica está em torno de $0,1 \mathrm{~cm} / \mathrm{s}$ (SILVA, 1983; SÃO PAULO, 1981).

Usou-se no experimento uma faixa de Geotēxtil oom 1,1 m de comprimento por $0,2 \mathrm{~m}$ de lagura. O Geotéxtil foi enrola do no dreno tubular, sendo amarrado com fio de nylon em laça das helicoidais sobre o eixo do tubo, dadas a espaços regula res. A largura da faixa empregada permitiu uma sobreposição de 20 a $25 \%$ do diámetro do dreno.

\subsubsection{Envoltório de Geotēxtil Bidim OP-30}

o Geotêxtil não tecido Bidim op-30 é uma man ta sintética fabricada a partir de filamentos continuos de poliéster interligados mecanicamente por agulhagem. A densidade superficial é de $300 \mathrm{~g} / \mathrm{m}^{2}$ e a espessura è de $3,5 \mathrm{~mm}$ apro 
ximadamente. Sua condutividade hidráulica é da ordem de 0,1 cm/s (SERAPHIM, 1982; SÃO PAULO, 1975).

o procedimento de instalação foi o mesmo des crito para o Geotêxtil OBER-851.

\subsection{Delineamento experimental}

o delineamento experimental adotado foi o de blocos casualizados, com 7 tratamentos e 3 repetições, totalizando 21 parcelas (GOMES, 1984). Os tratamentos foram assim enumerados:

Tratamento 1 - Filtro de pedregulho e areia com $10 \mathrm{~cm}$ de espessura;

Tratamento 2 - Envelope de brita no $1 \mathrm{com} 10 \mathrm{~cm}$ de espessura;

Tratamento 3 - Envelope de brita no $1 \mathrm{com} 5 \mathrm{~cm}$ de es pessura;

Tratamento 4 - Envelope de brita no $1 \mathrm{com} 2,5 \mathrm{~cm}$ de espessura;

Tratamento 5 - Geotêxtil ober-851;

Tratamento 6 - Geotēxtil Bidim OP-30;

Tratamento 7 - Ausência de envoltório.

Através de sorteio determinou-se a posição de cada tratamento no conjunto de tanques, obtendo-se o re- 
sultado expresso na Tabela 2 .

Por se ter construido apenas 7 tanques, as repetições não puderam ser feitas simultâneamente, o que justifica o delineamento experimental adotado.

O desempenho dos envoltórios foi avaliado

a partir de dados coletados durante a drenagem dos tanques, conforme será discutido no próximo item.

Tabela 2. Disposição dos tratamentos nos tanques em cada repetição

\begin{tabular}{cccccccc}
\hline $\begin{array}{c}\text { Blocos ou } \\
\text { Repetições }\end{array}$ & A & B & C & D & E & F & G \\
\hline 19 & 4 & 6 & 2 & 3 & 1 & 5 & 7 \\
29 & 2 & 6 & 3 & 1 & 7 & 5 & 4 \\
39 & 7 & 2 & 5 & 6 & 1 & 4 & 3 \\
\hline
\end{tabular}

\subsection{Procedimentos experimentais}

A preparação dos tanques foi iniciada com a colocação de uma camada de brita no 1 em seu fundo, com 4 a $5 \mathrm{~cm}$ de altura, seguida de adição de areia grossa suficiente para ocupar os espaços maiores entre as pedras. A finalidade foi obter uma zona de elevada permeabilidade, que auxiliasse a saturação uniforme do solo através do fluxo ascendente. 
A ação seguinte foi o enchimento dos tanques com solo até a altura de $30 \mathrm{~cm}$, para permitir a colocacão dos envoltórios. Naqueles tanques onde o sorteio indi cou o uso dos geotêxteis, estes foram enrolados e amarrados aos tubos e nos outros o material granular foi colocado ao redor dos arenos obedecendo a espessura pré-estabelecida. A seguir teve continuidade a colocação de solo. A Figura 6 mos tra um tanque com envoltório de brita no 1.

Em cada repetição foram usados aproximadamen te 11.000 quilogramas de solo, distribuidos em volumes iguais nos sete tanques. Para auxiliar a acomodação deste solo, procedeu-se a sua saturação e drenagem por vārias vezes, antes do inicio da coleta de dados. Isto resultou num abaixamento do nivel do solo nos tanques, que para as vinte e uma parcelas experimentais apresentou valor médio de $0,13 \mathrm{~m}$. - fato de se trabalhar com solo sem estrutura (grãos simples) e textura franco-arenosa, facilitou a ação homogeneizatória da água sobre a densidade do solo contido nos tanques.

No final da primeira e da segunda repetição, todo o material contido nos tanques foi retirado, féz-se a limpeza das 7 unidades e iniciou-se nova preparação, seguindo o procedimento já descrito. Não houve reaproveitamento de solo ou qualquer outro material.

A obtenção dos parāmetros experimentais foi feita a partir da elaboração de dados de vazão e massa de so 10 carreado pela ägua, obtidos durante a drenagem dos tan- 
ques.

Seis horas antes do início da coleta de dados, abriram-se as entradas de ägua para permitir a saturação do solo sob fluxo ascendente, simulando uma situação de elevação de lençol freático; quando a água atingiu o topo dos tanques cortou-se o fornecimento. A retirada datampa dos drenos deu início à contagem do tempo de rebaixamento do len çol freático. A partir deste momento, e em tempos pré-estabe lecidos, foram feitas medições de vazão e coletas de água pa ra avaliar a quantidade de solo em suspensão. A Tabela 3 apre senta os tempos em que foram feitas as medições de vazão.

Tabela 3. Início das medições de vazão, volume dos recipientes utilizados e intervalos de medição de vazão

Inicio das

Medições
Volume Coletado

(1itros)
Intervalo de Coleta (minutos)

\begin{tabular}{rcc}
\hline 5 segundos $^{\text {al }}$ & 10,6 & variável \\
4 minutos & 10,6 & variável \\
12 minutos & 10,6 & variável \\
24 minutos & 10,6 & variável \\
36 minutos & 7,1 & variável \\
48 minutos & 4,0 & variável \\
72 minutos & 2,5 & variável \\
96 minutos & variável & 5 \\
120 minutos & variável & 5 \\
\hline
\end{tabular}

a/ - Tempo transcorrido após o início da drenagem 

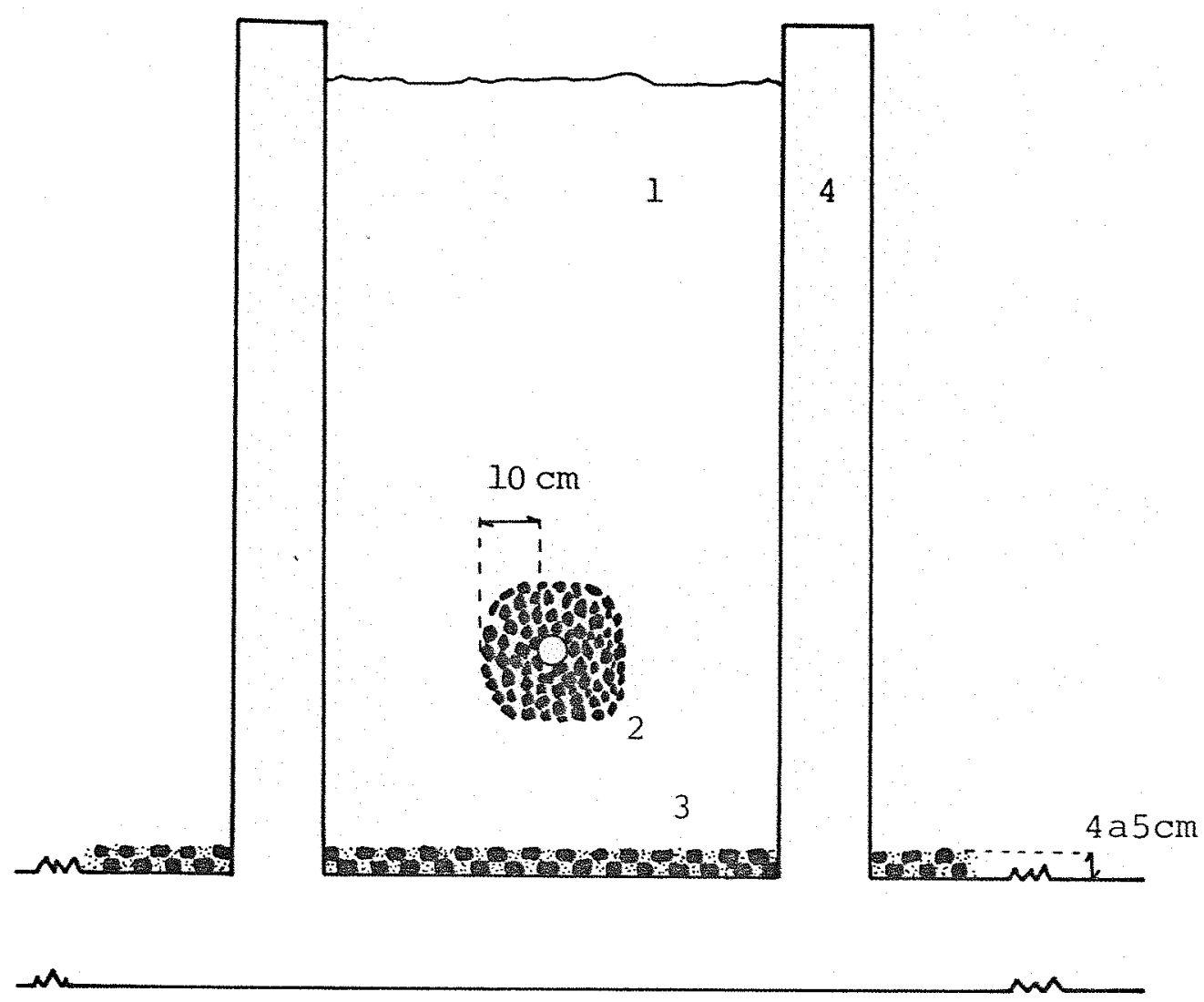

escala $1: 16$

Legenda:

1. Solo

2. Envoltório de brita no 1

3. Brita no 1 + areia grossa

4. Parede do tanque

Figura 6. Corte de um dos tanques com envoltörio de brita 
Um cronômetro digital foi usado para registrar o intervalo das medições de vazão. Cinco segundos após - inicio da drenagem, um balde plástico com volume de $10,6 \ell$ foi colocado sob a saida do dreno, permanecendo aí até ficar completamente cheio. Nesse momento, leu-se o tempo regis trado no cronômetro, determinando o final do intervalo de coleta. Da mesma forma, aos $4,12,24,36,48,72,96$ e $120 \mathrm{mi}$ nutos foram colocados recipientes de volume conhecido sob a saída dos drenos, para medir a vazão escoada em värios momen tos durante a drenagem dos tanques. A divisão do volume co letado pelo intervalo de tempo que durou a coleta, forneceu a vazão média no intervalo.

A Tabela 3 mostra que o volume dos recipientes empregados diminuiu com o tempo. Estes volumes foram ajustados em ensaio preliminar, para evitar sobreposição de leituras ou intervalos muito longos. Pela mesma razão, as duas ültimas medições foram feitas com intervalo fixo, medindo-se - volume coletado.

Após duas horas do início da drenagem, alguns tratamentos começaram a apresentar fluxo descontinuo, o que dificultou medições precisas. Resolveu-se por isso, tomar o tempo de duas horas como base para comparação entre os trata mentos.

Todas as medições foram feitas em recipiente exclusivo e numerado. A água coletada em cada um deles foi usada para determinar a quantidade de solo carreada para o 
dreno, pelo seguinte método: o conteüdo de cada recipiente foi passado através de peneira com abertura de 0,053 mm para separar a fração areia. As particulas retidas foram postas a sercar em estufa, a 105-107 graus centigrados, sendo a seguir pesadas em balança analítica, com precisão de 0,1 mg. A razão entre a massa de areia e o intervalo de tempo em que se deu a coleta, forneceu a taxa de carreamento média no intervalo considerado.

A opção de reter e pesar apenas a fração areia deveu-se a duas razões: com relação a argila, sabe-se que quando a linha de drenos tem declividade adequada, essas par tículas são transportadas com a água drenada sem se deposi tar, não causando problemas (BATISTA, 1978); quando ao silte, embora seja causa comum de obstrução de drenos, sua presença não foi considerada por ser muito pequena no solo empregado (vide Figura 4 do item 3.2., mostrando a distribuição granulométrica das partículas do solol.

Após a preparação dos tanques para o início da primeira repetição, houve problemas no abastecimento de água da rede urbana, provocando o adiamento do ínicio da coleta de dados de novembro de 1986 para março de 1987 . Na se gunda e na terceira repetição, a coleta de dados teve início, respectivamente, três e duas semanas após o término da prepa ração dos tanques. Este fato gerou diferença na magnitude đos dados de vazão coletados na primeira repetição em relação às seguintes, o que se explica pelo maior tempo de oportuni- 
dade para estruturação, que aumentou a condutividade hidrāulica do solo na primeira repetição. A densidade do solo variou entre repetiçōes, mas dentro das repetiçōes, as condições foram semelhantes para o solo contido nos sete tanques. Isto, no entanto, não interferiu na comparação entre os tratamentos, porque o delineamento experimental adotado permitiu a separação do efeito devido a blocos. Os valores de densida de média encontrados para o solo contido nos tanques foram os seguintes: 1,$35 ; 1,44$ e $1,52 \mathrm{~g} / \mathrm{cm}^{3}$ para as trēs repetiçöes, respectivamente.

As trēs repetiçōes foram realizadas no ano de 1987, sendo que na primeira delas houve coleta de dados nos dias $13,17,20,24$ e 27 de março, na segunda nos dia 20,23, 26 e 30 de maio e 6 e 10 de junho, e na terceira repetição nos dias $17,20,24,27$ e 31 de agosto. Procurou-se manter um intervalo de 3 a 4 dias entre coletas sucessivas, sendo que apenas a do dia 30 de maio, na 29 repetição, ficou com. 6 dias de intervalo da coleta anterior. Foi feito então um 69 rebai xamento do lençol freático na referida repetição, de modo a se ter mais dados para o cálculo da média, diluindo assim a influéncia de efeitos não controlados.

O encerramento das repetições foi determinado a partir da observação dos resultados obtidos. Quando as vazões nos diferentes tratamentos se aproximaram da estabili zação, encerrou-se a coleta de dados. Não se teve como obje- 
tivo, a análise do comportamento dos tratamentos comotempo, de modo que os rebaixamentos foram considerados como sub-amostras coletadas para tornar os resultados mais representativos.

3.6. Lâmina Iiquida drenada em duas horas

As lâminas líquidas drenadas por metro de tu bo em duas horas, para todos os tratamentos, foram obtidas a partir dos resultados de vazão.

Plotou-se em um gräfico os valores de vazão, em litros por minuto, no eixo das ordenadas e em escala loga ritmica. No eixo das abcissas, em escala decimal, representou-se com traços horizontais os intervalos de tempo gastos nas medições de vazão e marcou-se também o ponto médio dos in tervalos. A Figura 7 apresenta um exemplo de curva obtida a partir dos dados de vazão, ajustada manualmente. Foram obtidas 16 curvas semelhantes a do exemplo para cada tratamento, representando os Hidrogramas de variação de vazão dos 16 rebaixamentos do lençol freático realizados durante o experimento. O número total de curvas obtidas foi de 112 .

O cálculo da área existente sob as curvas ob tidas forneceu o volume drenado em litros por metro de tubo, no período de duas horas. Calculou-se também o volume drenado a cada 10 minutos, que foi acumulado e representado em gră ficos denominados curvas de descarga, nas Figuras 8 a 14. 


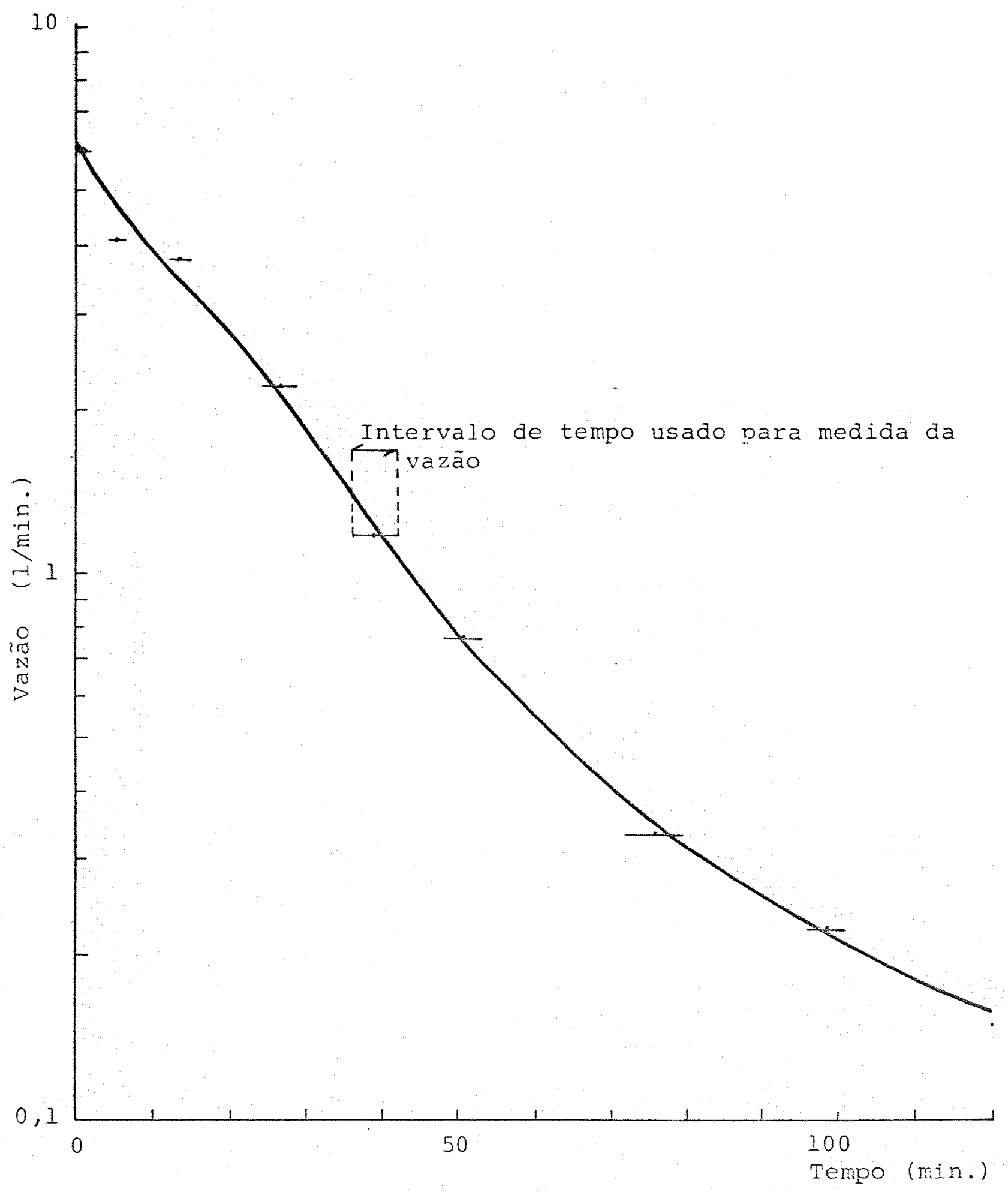

Figura 7. Hidrograma da variação de vazão durante a drenagem de tanque com areno envolto por filtro de pedregulho e areia. 


\subsubsection{Processo de cálculo}

o método adotado para calcular a área sob as curvas foi a Regra de Simpson, que aproxima o valor da integral

$$
I=\int_{x 0}^{x n} f(x) d x
$$

onde $o$ valor de $f(x)$ deve ser conhecido em $n+1$ pontos ( $f 0-f n$ ) igualmente espaçados. A fórmula empregada foi:

$\int_{x 0}^{x n} f(x) d x \cong h / 3 \quad(f 0+4 f 1+2 f 2+4 f 3+2 f 4+\ldots+2 f n-2+$

$$
+4 f n-1+f n)
$$

onde

$\mathrm{h}=(\mathrm{xn}-\mathrm{x} 0) \div \mathrm{n}, \mathrm{xn}>\mathrm{x} 0$

$\mathrm{n}=$ número de sub-intervalos $(2,4,6,8, \ldots)$

Adotou-se sub-intervalos de 5 minutos, de mo do que nos tempos $0,5,10,15, \ldots 110,115$ e 120 minutos, re tirou-se pares de valores das curvas Tempo x Vazão para reali zar o cálculo. Este foi feito com o auxilio de cálculadorapro gramável que possui programa residente para o emprego da Regra de simpson.

Para cada uma das 112 curvas obtidas, calculou-se o valor do volume drenado por metro de tubo em 
duas horas. Obteve-se dessa forma, para cada tratamento, 5 va lores de volume drenado na lä e na 3ạ repetição e 6 valoresna 2 a repetição, referentes ao número de rebaixamentos realizados. Estes resultados, considerados como sub-amostras, foram usados para o cálculo do volume médio arenado por metro de tú bo, para cada tratamento, nas 3 repetições.

As Iäminas Iiquidas drenadas por metro de tu do, foram obtidas fazendo.se a divisão do volume médio drenado por metro de tubo $\left(\mathrm{m}^{3}\right)$, pela área superficial dos tanques $\left(\mathrm{m}^{2}\right)$. O valores foram expressos em milimetxos e estão representados na Tabela 22 do Apénaice II.

\subsubsection{Análise estatistica}

A análise de variāncia das lâminas líquidas drenadas por metro de tubo em duas horas, nas três repeticões, foi efetuada conforme o esquema da Tabela 4. Utilizou-se otes te de Duncan a 5\% de probabilidade para a comparação das médias entre tratamentos.

\subsection{Lāmina minima satisfatória}

Definiu-se como lâmina de drenagem mínima są tisfatória para os tratamentos, a lâmina liquida corresponden te à metade da água contida nos macroporos do solo localizado acima dos drenos, mais a água da superficie dos tanques. Esse valor padrão é arbitrário, e foi criado para estabelecer o 
desempenho minimo aceitável para os tratamentos testados.

Tabela 4. Esquema de análise de variância

Causa de variação

Graus de Liberdade

Blocos

2

Tratamentos

6

Resíduo

o cálculo da lāmina mínima satisfatória foi feito da seguinte forma:

a - Volume de água médio contido nos macroporos do solo (Vm)

Dados :

- altura de solo acima dos drenos (média de vinte e uma parcelas) $=96,7 \mathrm{~cm}$

- área superficial dos tanques $=8.000 \mathrm{~cm}^{2}$

- macroporosidade média do solo empregado $=15 \%(*)$ $\mathrm{Vm}=96,7 \times 8.000 \times 0,15=116.040 \mathrm{~cm}^{3}$

(*) Valor obtido após drenagem livre de amostras indeformadas de solo, em laboratório. 
b - Volume de água médio contido na superfície dos tanques (Vs)

Dados:

- altura sem solo na superfície dos tanques (mé dia de vinte e uma parcelas) $=13,3 \mathrm{~cm}$

$\therefore$ área superficial dos tanques $=8.000 \mathrm{~cm}^{2}$ $V s=13,3 \times 8.000=106.400 \mathrm{~cm}^{3}$

c - Lãmina minima satisfatória (Is)

$(\operatorname{Vm} \times 0,5)+V s$

$L S=$

ārea superficial dos tanques

$(116.040 \times 0.5)+106.400$

$L S=\longrightarrow=20,55 \mathrm{~cm}=205,5 \mathrm{~mm}$

8.000

A arenagem da lâmina de 205, $5 \mathrm{~mm}$ foi tomada como o valor minimo para que o desempenho do tratamento pudesse ser considerado satisfatório. O tempo médio para atingir os $205,5 \mathrm{~mm}$ foi usado como uma forma de avaliar a veloci dade de drenagem dos tratamentos testados.

3.8. Taxas de carreamento de solo

Conforme descrito no item 3.5., o carreamento de solo para os arenos foi estimado a partir da massa de 
areia contida nos recipientes usados nas medições de vazao. Para cada medição de vazão obteve-se uma taxa de carreamento de solo.

Durante as duas horas de drenagem foram obti das nove taxas de carreamento para cada tratamento, expressas em miligramas de areia por minuto, por metro de dreno. os tempos de amostragem foram os mesmos das medições de vazão, ou seja, 5 segundos, $4,12,24,48,72,96$ e 120 minutos. As ta xas médias foram calculadas dividindo-se o somatório das mas sas de solo coletadas nos 16 rebaixamentos, pelo somátório dos intervalos de tempo em que se deram as coletas. 
51.

\section{RESULTADOS E DISCUSSÃO}

os dados originais do experimento, referentes a volumes coletados nas medições de vazão, tempo de duração das coletas de volume, massa de solo carreado com a água dre nada e lâminas Iíquidas drenadas em duas horas por metro de tubo, para os sete tratamentos, estão contidos no Apéndice II.

4.1. Efeito dos tratamentos na lâmina Iiquida drenada em duas horas

A análise de variāncia das lāminas liquidas drenadas por metro de tubo em duas horas está apresentada na Tabela 5. O teste $F$ mostrou resultado significativo ao nivel de $5,35 \%$ de probabilidade para tratamentos. A comparação entre as lâminas médias drenadas por metro de tubo em duas horas, nos sete tratamentos, foi feita pelo teste de Duncan e 
encontra-se representada na Tabela 6 .

Tabela 5. Anālise de variância das lâminas líquidas arenadas por metro de tubo em duas horas

\begin{tabular}{lrrrc}
\hline Causas da variação & G.L. & S.Q. & Q.M. & F \\
\hline Blocos & 2 & $217.316,22$ & $108.658,11$ & $116,17 * *$ \\
Tratamentos & 6 & $16.564,60$ & $2.760,77$ & $2,95 *$ \\
Residuo & 12 & $11.223,85$ & 935,32 & - \\
\hline Total & 20 & $245.104,67$ & - & - \\
\hline
\end{tabular}

C.V. $=14,39 \%$

* Significativo ao nivel de 5,35 o de probabilidade

* Significativo ao nivel de 1\% de probabilidade

- filtro de pedregulho e areiapossibilitou a drenagem de uma lâmina de $255,8 \mathrm{~mm}$ em duas horas, que foi a maior entre os sete tratamentos testados. Este valor diferiu estatisticamente das läminas drenadas pelos tratamentos geotéxtil ober 851 e auséncia de envoltório ao nivel de 5\% de probabilidade. Não houve diferença estatistica em relação a outros tratamentos.

A segunda e a terceira läminas, em ordem decrescente de grandeza, foram drenadas pelos envelopes de bri ta com $5 \mathrm{~cm}$ e $10 \mathrm{~cm}$ de espessura, com $233,3 \mathrm{~mm}$ e 223,9 mm res pectivamente. Estes valores diferiram estatisticamente apenas da lâmina drenada pelo tratamento ausência dé envoltório.

A quarta maior lámina foi drenada pelo trata mento geotêxtil Bidim OP-30, com 221,0 mm, e a quinta maior 
Tabela 6. Valores médios de lâminas líquidas drenadas por metro de tubo em duas horas

\begin{tabular}{lll}
\hline & Lâmina média drenada Acréscimo em relação \\
& por metro de tubo em & ao tratamento sem \\
duas horas (mm) & envoltório (\%) \\
\hline
\end{tabular}

Filtro de pedregulho
e areia
$255,8 a^{*}$
55,3

Envelope de brita no

1 com $10 \mathrm{~cm}$ de espes

sura

223,9 a b

35,9

Envelope de brita no

1 com 5 cn de espes-

sura

233,3 a b

41,6

Envelope de brita com

$2,5 \mathrm{~cm}$ de espessura

200,5 a b c

21,7

Geotêxtil ober 851

188,3 b c

14,3

Geotêxtil Bidim

$\mathrm{OP}-30$

221,0 a b c

34,2

Ausência de envoltó-

rio

164,7

c

* Valores seguidos por letras distintas diferem entre si pelo teste de DUNCAN ao nivel de $5 \%$ de probabilidade. 
lâmina foi aquela drenada pelo envelope de brita de $2,5 \mathrm{~cm}$ de espessura, com 200,5 mm. Estes dois tratamentos não diferiram estatisticamente de nenhum dos demais.

As menores Iâminas foram drenadas pelo geotêxtil ober 851, com $188,3 \mathrm{~mm}$ e pelo tratamento ausência de envoltório, com $164,7 \mathrm{~mm}$.

O melhor desempenho observado para os três tratamentos de maior espessura em relação ao tratamento ausência de envoltório pode ser atribuido a dois fatores: o au mento da condutividade hidráulica propiciado pela colocação de material de grande permeabilidade ao redor do dreno e a ampliação do raio efetivo do dreno.

O tratamento sem envoltório apresentou o menor valor de lämina média drenada por metro de tubo em duas horas, embora não tenha diferido estatisticamente dos dois geotēxteis e do envelope de brita no 1 com $2,5 \mathrm{~cm}$ de espessu ra. No caso dos geotêxteis, o aumento da condutividade hidráulica pode ser atribuido à auto formação de uma camada per meável junto ao dreno, ocasionada pela ação seletiva da manta ao reter particulas grossas e permitir a passagem das de diāmetro menor, conforme explica SILVA (1983).

A Tabela 6 apresenta na sua terceira coluna, - acréscimo percentual na lämina drenada pelos diferentestra tamentos em relação ao tratamento sem envoltório. Pode-se ob servar que o acréscimo proporcionado pelo emprego do envelo- 
pe de brita no 1 com $10 \mathrm{~cm}$ de espessura, que foi de $35,9 \%$, é praticamen te igual ao acréscimo correspondente ao uso do geotêxtil Bidim OP-30, que foi de $34,2 \%$. A ocorrência de desempenhos equivalentes entre os tratamentos leva a considerações sobre a pra ticidade e custo dos envoltórios.

os envoltórios de material granular apresentam uma desvantagem em relação aos geotêxteis, pelo seu maior peso. Para confeccionar um envoltório ou um filtro de pedregulho e areia com $10 \mathrm{~cm}$ de espessura, são necessários, aproximadamente, $5 \mathrm{~m}^{3}$ de material granular para cada $100 \mathrm{~m}$ de tubo, com peso de algumas toneladas. Uma faixa de geotéxtil Bidim oP-30 com $0,2 \mathrm{~m}$ de largura e $100 \mathrm{~m}$ de comprimento pesa aproximadamente 6 quilogramas.

Além de ter maior peso, que encarece o trans porte, o material granular é de colocação lenta e exige mais mão-de-obra que o geotéxtil, uma vez que não está difundido no Brasil o uso de máquinas para descarga automática de brita ou pedregulho, como há em outros países (PIZARRO, 1975; HO LANDA, 1984).

o filtro de pedregulho e areia propiciou a drenagem da maior lâmina média por metro de tubo no período de duas horas. Seu uso, no entanto, somente será vantajoso se for possivel obter material natural com as características de sejadas, uma vez que as operações de peneiramento ou mistura de materiais diferentes para se chegar ao filtro aumentam mui to o seu custo. 
4.2. Curvas de descarga e tempo necessário para drenagem da lâmina minima satisfatória

As figuras de no 8 a 14 apresentam as curvas médias de descarga dos sete tratamentos testados. Nessas cur vas pode-se observar o crescimento da lámina média drenada por metro de tubo no periodo de duas horas.

o coeficiente angular de uma reta tangente a qualquer ponto das curvas de descarga fornece o valor médio da taxa de drenagem no instante considerado. A variação da inclinação, que se verificou com o aumento do tempo em todas as curvas, deveu-se à redução da carga hidráulica durante a arenagem dos tanques. Diferenças na inclinação das curvas, principalmente aquelas verificadas nos momentos iniciais da drenagem, quando ainda não havia diferenças considerāveis na carga hidräulica dos sete tanques, indicam condutividade hidráulica distinta para os tratamentos testados. As maiores condutividades hidráulicas levaram a um menor tempo para dre nagem da lāmina mínima satisfatória.

Somente quatro tratamentos alcançaram a drenagem da lāmina mínima satisfatória em tempo médio inferior a duas horas: o filtro de pedregulho e areia, os envelopes de brita no 1 com $10 \mathrm{~cm}$ e $5 \mathrm{~cm}$ de espessura e o geotêxtil Bidim op-30. o filtro de pedregulho e areia foi o mais rápido, demorando 40 minutos para drenar os $205,5 \mathrm{~mm}$. A seguir vieram o envelope de brita no 1 de $5 \mathrm{~cm}$ de espessura com 57 minútos, 
- envelope de brita no 1 de $10 \mathrm{~cm}$ de espessura com $83 \mathrm{minu-}$ tos e o geotêxtil Bidim op-30 com 102 minutos.

Os demais tratamentos alcançaram a drenagem da lâmina mínima satisfatöria em tempo superior a duas horas. Cabe ressaltar, que a velocidade de drenagem dentro do intervalo de tempo de duas horas tem interesse específico para o experimento, pois em condições de campo, o tempo mínimo considerado para o rebaixamento do lençol freático a níveis aceitáveis é de 24 horas.

\subsection{Efeito dos tratamentos no carreamento de solo}

A Tabela 7 apresenta as taxas médias de carreamento de solo por metro de dreno, para todos os tratamentos, expressas em miligramas de areia por minuto.

os resultados mostraram que para seis tratamentos, a primeira taxa média de carreamento foi muito maior que as taxas subsequentes. Esta taxa inicial representa o carreamento médio ocorrido nos momentos iniciais de drenagem, pois sua determinação teve início 5 segundos após a abertura dos drenos. Apenas o tratamento geotêxtil Bidim OP-30 apresentou a taxa média inicial com valor um pouco menor que o da segunda taxa. 


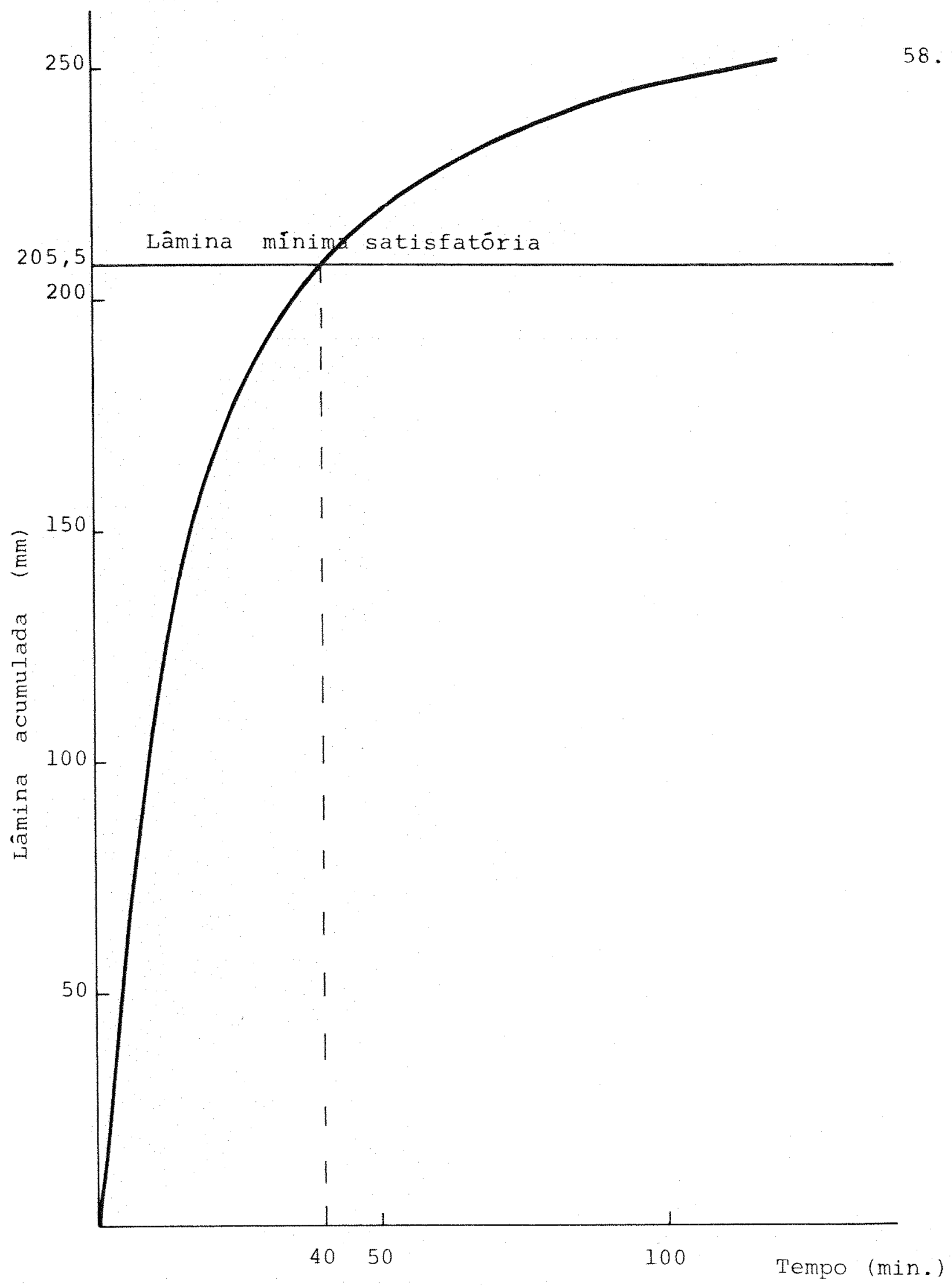

Figura 8. Curva de descarga do tanque com areno envolto por filtro de pedregulho e areia. 


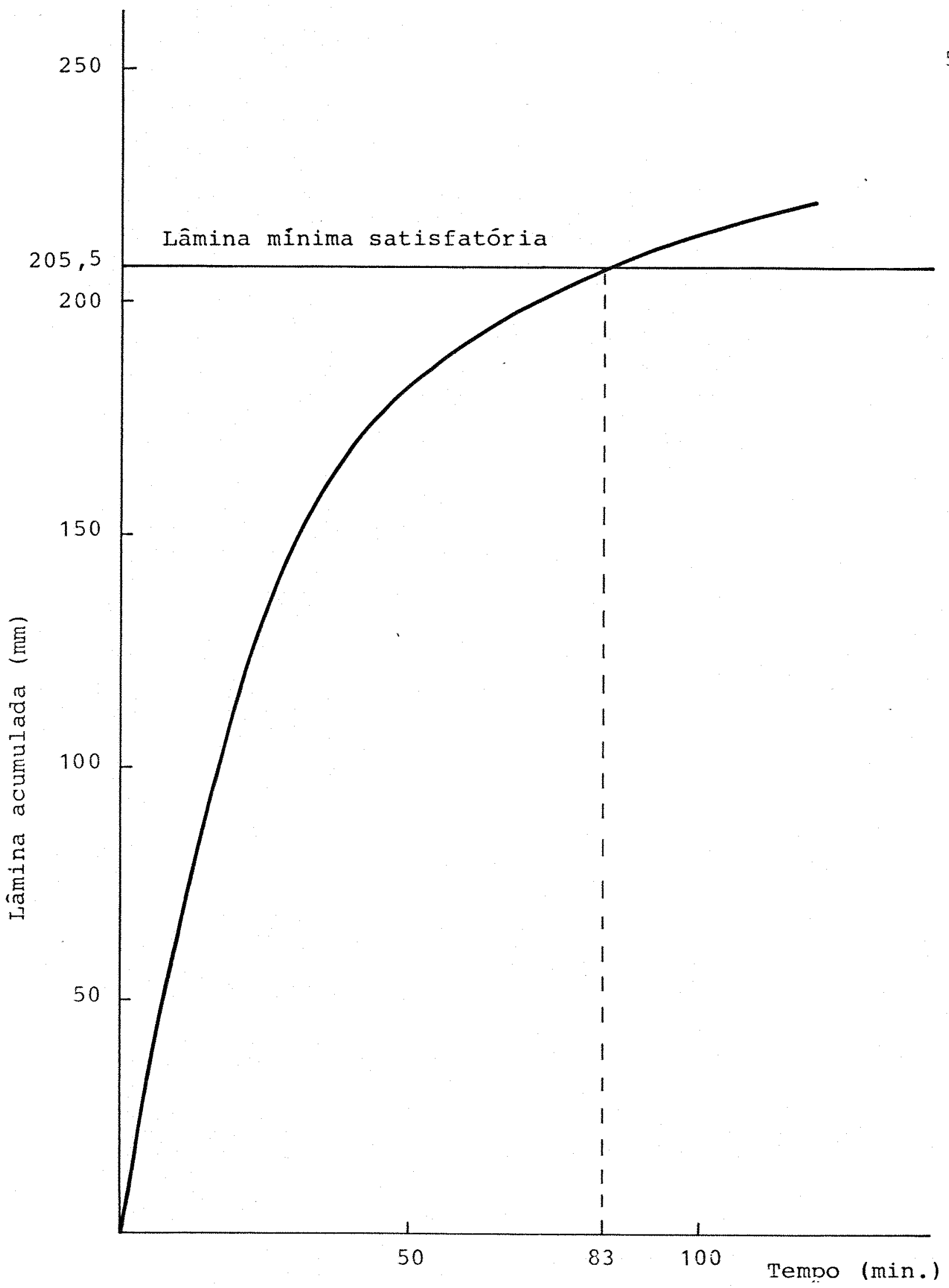

Figura 9. Curva de descarga do tanque com dreno envolto por envelope de brita no $1 \mathrm{com} 10 \mathrm{~cm}$ de espessura. 


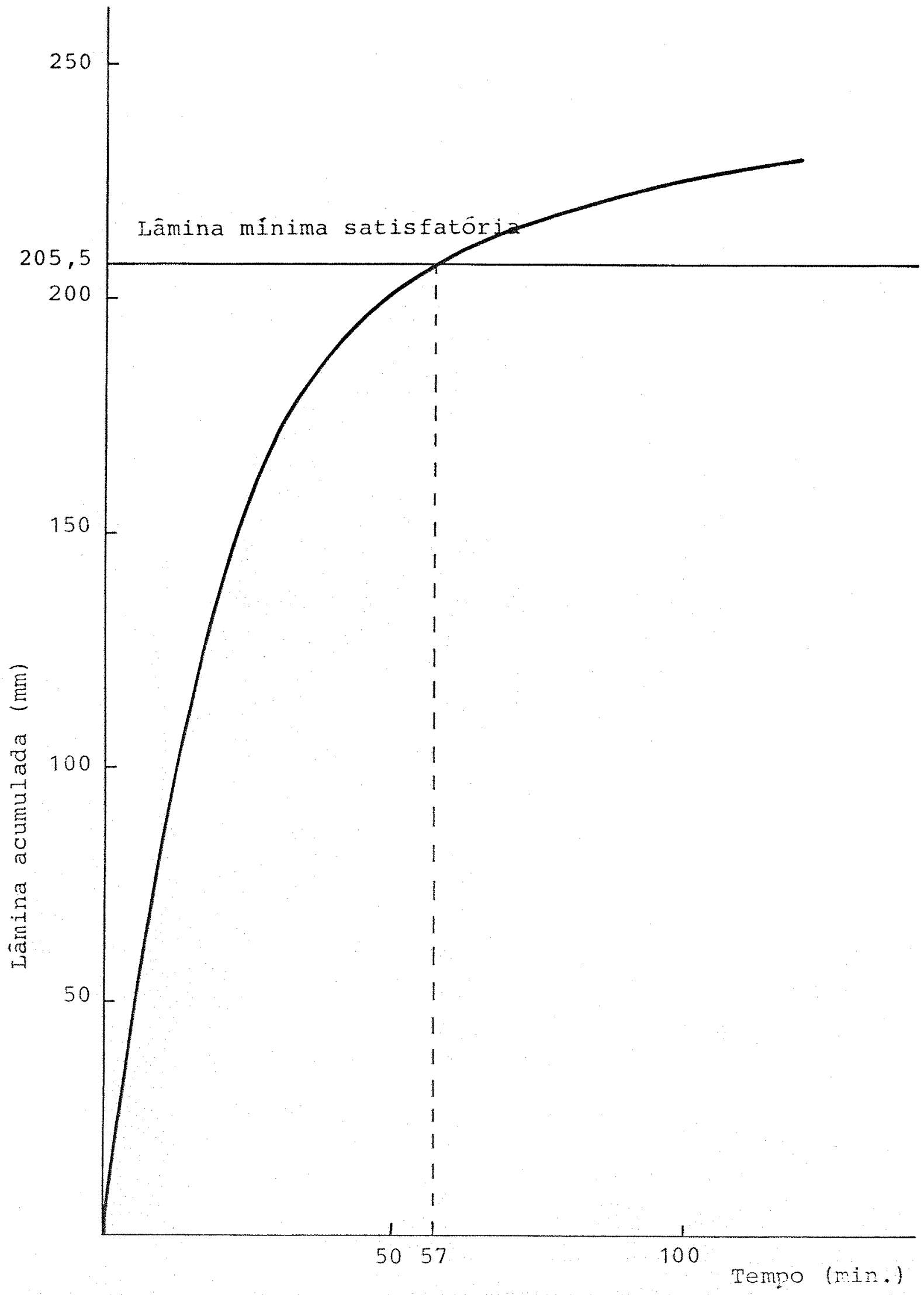

Figura 10. Curva de descarga do tanque com dreno envolto por envelope de brita no $1 \mathrm{com} 5 \mathrm{~cm}$ de espessura. 


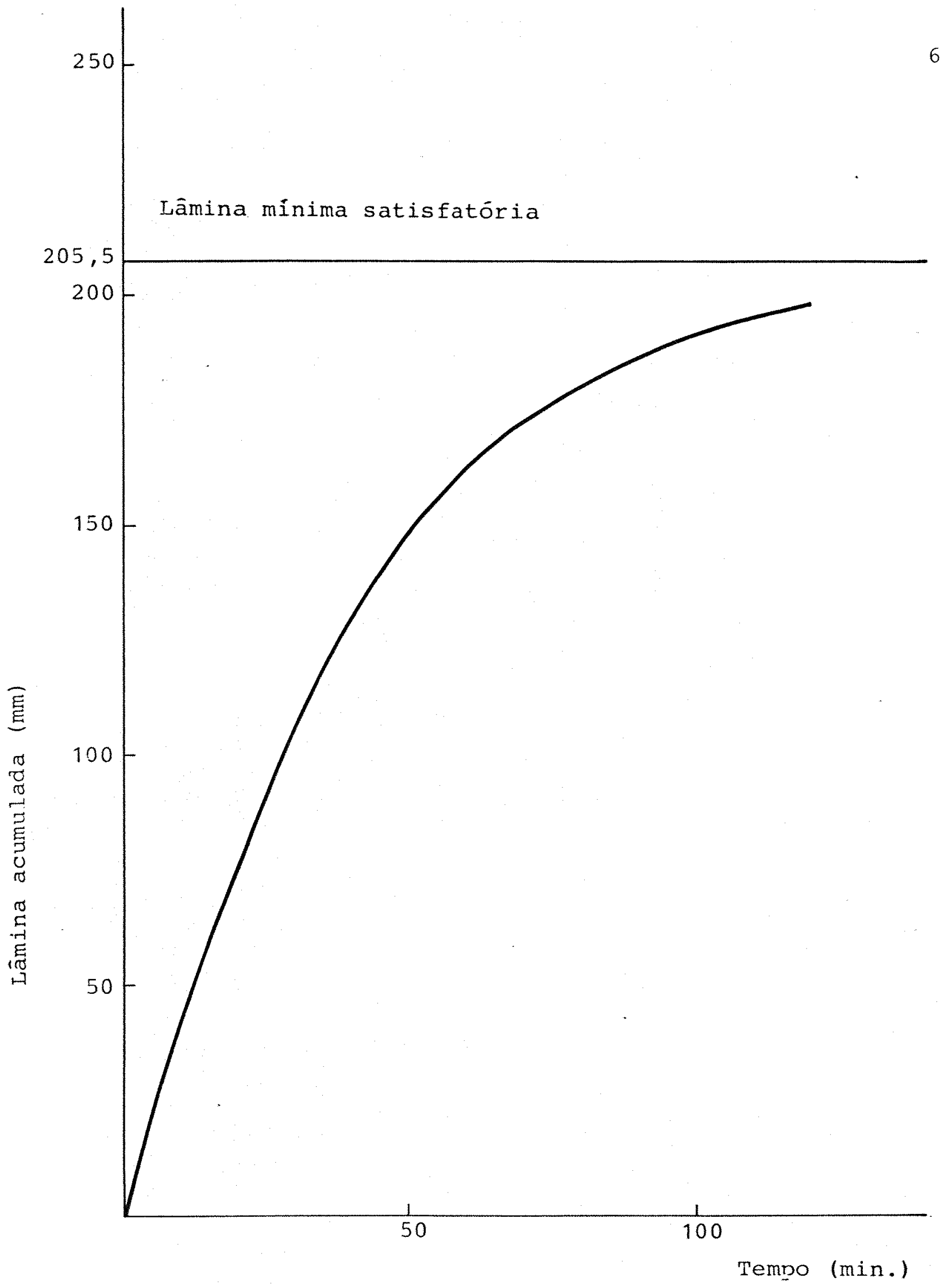

Figura 11. Curva de descarga do tanque com dreno envolto por envelope de brita no $1 \mathrm{com} 2,5 \mathrm{~cm}$ de espessura. 


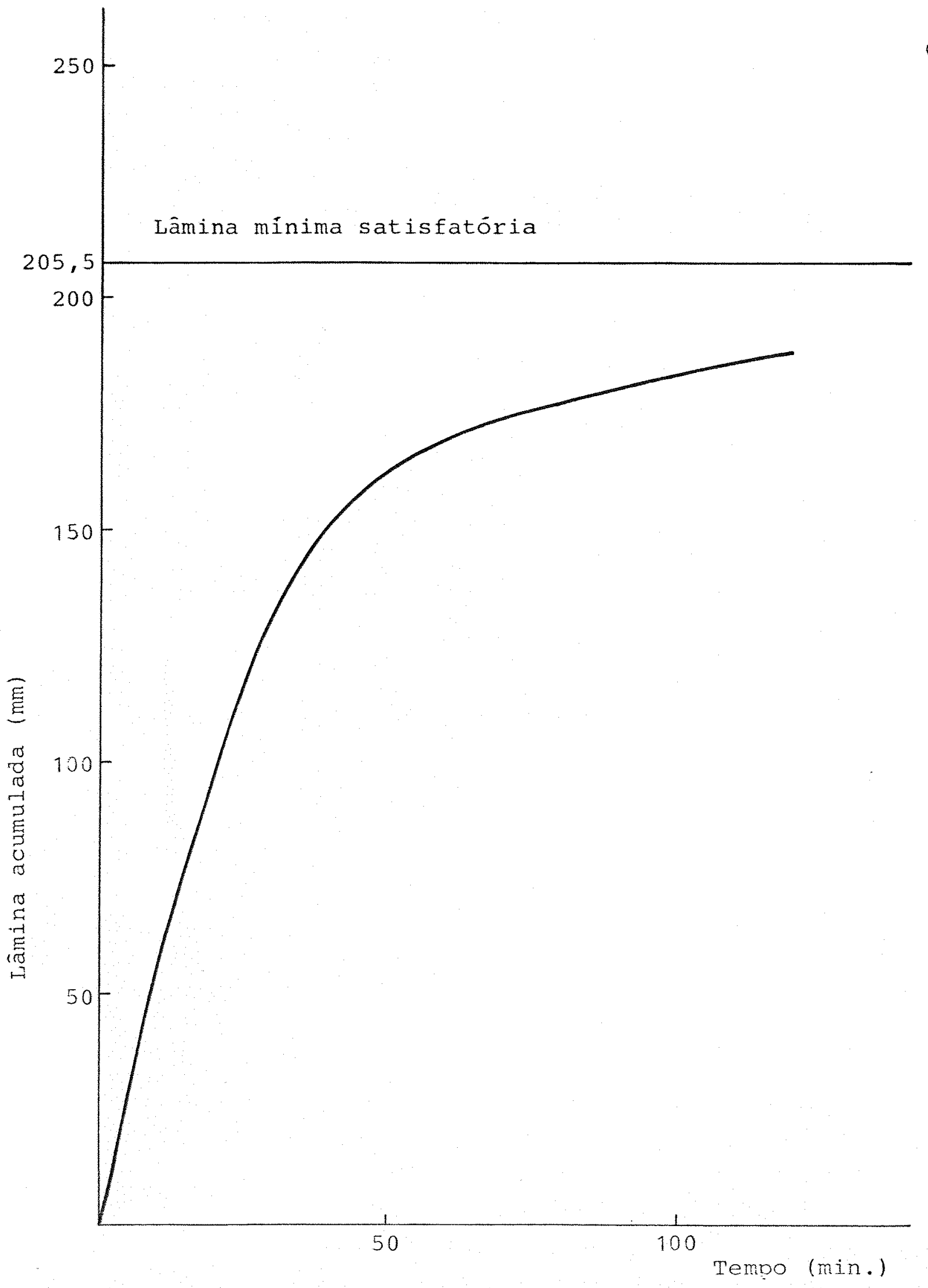

Figura 12. Curva de descarga do tanque com dreno envolto por gectêxtil ober 851 . 


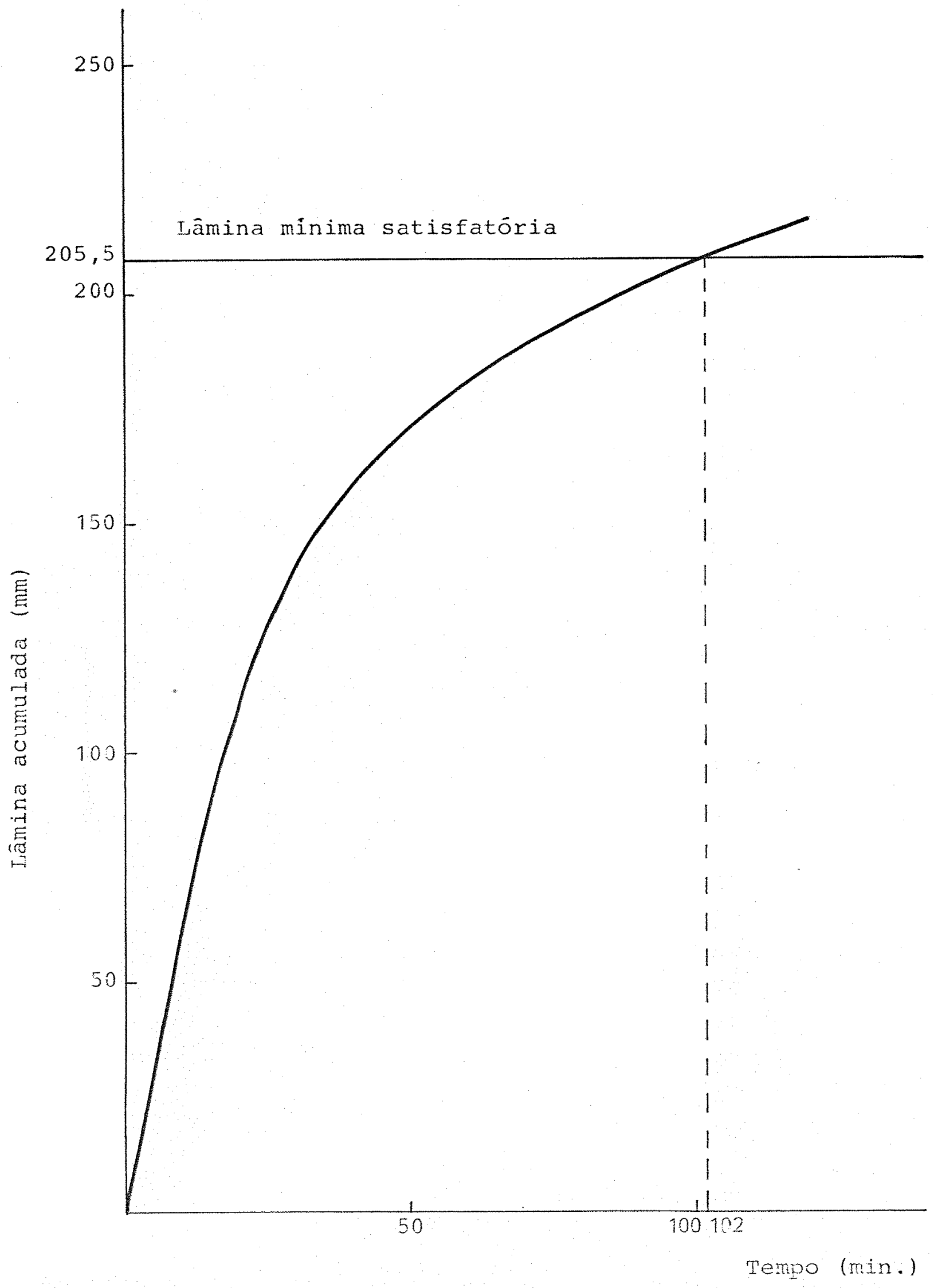

Figura 13. Curva de descarga do tanque com dreno envolto por geotêxtil Bidim op-30. 


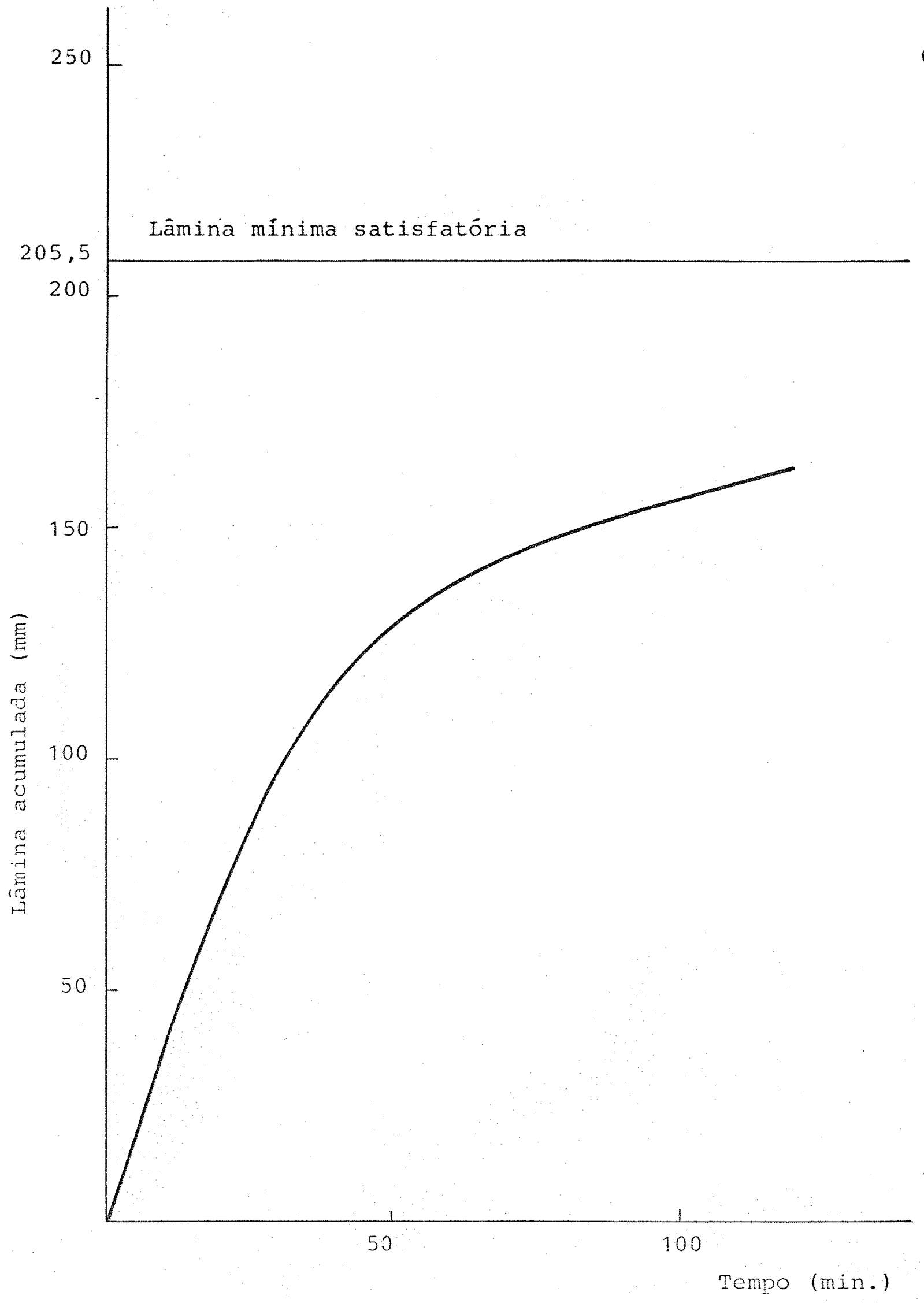

Figura 14. Curva de descarga do tanque com dreno sem envoltório. 


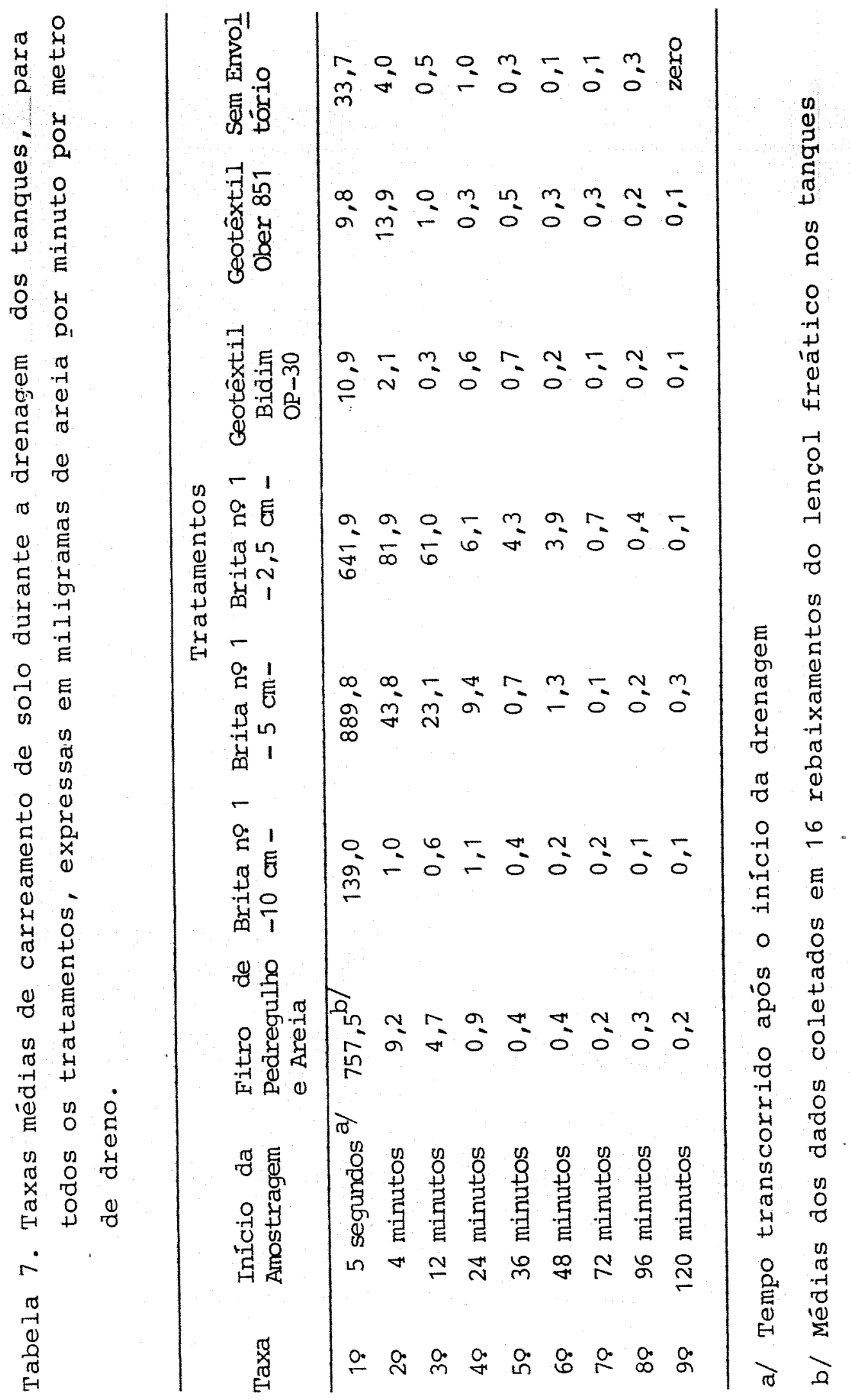


Após uma queda acentuada da primeira para a segunda taxa, houve um decréscimo gradual dos valores parato dos os tratamentos, que prosseguiu até os $36-48$ minutos. A partir daí as taxas permaneceram estáveis até os 120 minutos, apresentando valores de carreamento sempre menores que $1 \mathrm{mi-}$ ligrama de areia por minuto, por metro de dreno.

o acentuado carreamento registrado nos minutos iniciais, pode ser atribuído a uma situação momentânea de instabilidade e desarranjamento das particulas de solo, devido ao início da drenagem. O reordenamento destas partícu las, à medida que prosseguiu a percolação, proporcionou uma nova acomodação que ocasionou a redução do carreamento. Essa afirmação tem por base a seguinte consideração: A carga hidráulica existente sobre o dreno diminuiu muito pouco nos 4 ou 5 minutos em que se produziu a redução brusca no carreamento. Isto demonstra que o gradiente de saida, que gera a força de percolação, não sofreu decréscimo tão acentuado a ponto de provocar grandes alterações na taxa de carreamento. A ređução gradual no valor das taxas médias de carreamento ocorrida a partir da segunda amostragem, pode ser atribuía à diminuição da carga hidráulica nos tanques, que se deu em função da drenagem.

o uso da primeira taxa média de carreamento como parâmetro de comparação entre os tratamentos não foi con siderado apropriado, visto que esses valores refletiram uma condição momentānea ocasionađa pela abertura dos drenos. As 
taxas médias registradas a partir de 4 minutos após o início da drenagem, mostraram de forma mais correta o efeito dos tratamentos no carreamento de solo.

A observação dos resultados apresentados na Tabela 7 mostra que a partir dos 4 minutos de drenagem, registrou-se taxas de carreamento pequenas para todos os trata mentos. Mesmo com carga hidráulica próxima do valor máximo, a maior taxa média registrada aos 4 minutos foi de 81,9 miligramas de areia por minuto, por metro de dreno, para o trata mento envelope de brita no $1 \mathrm{com} 2,5 \mathrm{~cm}$ de espessura. Considerando que tivéssemos 100 metros de dreno e que a carga hidráulica permanecesse elevada por 3 horas devido a uma preci pitação muito intensa, o carreamento total de solo para o dreno por esse tratamento, seria de aproximadamente 1.400 gra mas de areia, que representa um volume em torno de 1 litro.

Em face dos resultados obtidos, as taxas médias de carreamento não foram utilizadas parą comparar o desempenho dos envoltórios, pois considerou-se que o solo empregado influiu mais no resultado do que o efeito dos tratamentos. Em outras palavras, pode-se dizer que apesar da expec tativa de que viesse a ocorrer um significativo carreamento de partículas em função das caracteristicas do solo empregado, isto, como mostra o comportamento do tratamento ausência de envoltório, não ocorreu. Face ao exposto, não foi possivel identificar com precisão o efeito dos tratamentos no con 
68.

trole do carreamento de solo para os drenos.

Segundo GULATI et alii (1970), solos não coe sivos de textura grossa podem ser resistentes ao carreamento de solo se apresentarem boa graduação de particulas. 


\section{CONCLUSÕES}

Para as condiçöes em que foi realizado este trabalho e considerando o solo empregado, tirou-se as seguintes conclusões:

1 - As laminas drenadas no período de duas horas pelos drenos com envoltório de espessura maior ou igual a $5 \mathrm{~cm}$, foram estatisticamente diferentes e superiores à lāmina arenada no mesmo periodo pelo dreno sem envoltório.

2 - o envelope de brita com $2,5 \mathrm{~cm}$ de espessura e os geotêxteis Bidim OP-30 e ober 851, proporcionaram um acréscimo na lämina drenada em duas horas em relação ao tratamento sem envoltório de $21,7 \%, 34,2 \%$ e $14,3 \%$, respectivamente, embora não se tenha encontrado diferença estatistica ao nível de 5\% de probabilidade.

3 - os tratamentos filtro de pedregulho e areia, envelope de brita com $5 \mathrm{~cm}$ e $10 \mathrm{~cm}$ de espessura e o geotêxtil Bidim OP-30 foram, nesta ordem, os de maior velocidade de dre- 
nagem, demorando 40 minutos, 57 minutos, 83 minutos e 102 minutos, respectivamente para drenar uma lâmina de 205,5 $\mathrm{mm}$.

4 - O efeito dos tratamentos no controle do carreamento de solo para os drenos não pode ser estimado com precisão, em função das pequenas taxas de carreamento de solo encontradas.

5 - Considerando-se o efeito dos envoltórios testados no aumento da capacidade de drenagem, o filtro de pedregulho e areia foi o envoltório que apresentou melhor desempenho.

6 - Considerando-se juntamento com o efeito no aumento da ca pacidade de drenagem, a praticidade de instalação e a eco nomia de mão-de-obra e de transporte, o geotêxtil Bidim oP30 foi o envoltório que apresentou melhor desempenho. 


\section{LITERATURA CITADA}

AL-SOUFI, R.W., 1981. Alternative for Envelope Material. Chicago, Am.Soc.Agric.Engrs., 9p. (Paper ne 81-2541). BATISTA, M.J., 1978. Effect of Soil Compaction on Hidraulic Failure of Soils. Logan, UTAH STATE UNIVERSITY, 108p. (Dissertação de Mestrado).

BATISTA, M.J., 1983. Envelopes para Drenos Subterrâneos. Irrigação e Tecnologia Moderna. Brasilia, 12: 26-29. BATISTA, M.J.; C.L. SILVA e J.D. RODRIGUES, 1984. Análise Técnico-Econômica do Comportamento de Drenos Entubados em pregando Envelope somente de Cascalho e de Cascalho com Manta Sintética. Irrigação e Tecnologia Moderna. Brasilia, 19: $14-22$.

BROUGHTON, R.S.; S. GAMEDA e W. GIBSON, 1982. Field Tests of some Drain Tube Envelope Materials. In: KRIZ, G.J., Ed. Advances in Drainage. St. Joseph, Am.Soc.agric.Engrs., p. 69-78. 
CAVELAARS, J.C., 1974. Subsurface Field Drainage systems In: The Netherlands. International Institute for Land Re clamation and Improvement., Ed. Drainage Principles and Aplications. Wageningen, ILRI, Vol. IV, p. 1-65. (Publicação 16$)$.

CRUCIANI, D.E., 1980. A Drenagem na Agricultura. São Paulo, Livraria Nobel. $333 p$.

DAVIS, S.; WILLARDSON; J.R. SPENCER E D. MULDER, 1971.. Drain Envelope Performance in a Sandy Soil. In: National Drainage Symposium. St. Joseph, Am.Soc, agric.Engrs., p. 8-10, 19.

DONNAN, W.W. e G.O. SCHWAB, 1974. Current Drainage Methods in the USA. In: SCHILFGAARDE, J.V., Ed. Drainage for Agriculture. Madison. American Society of Agronomy, p. 93-114. (Série Agronomy, 17).

EEUU. U.S.Dep.Agr.. Soil Conservation Service, 1971. Draina ge of Agricultural Lands. Port Washington. 460p. EEUU. U.S.Dep.Agr.. Soil Conservation Service, 1972. Maintaining Subsurface Drains. Washington, D.C., 8p. (Leaflet no 557).

GRASS, L.B., 1969. Tile Clogging by Iron and Manganese in Im perial Valley, California. J. Soil and Water Cons., Baltimore 24 (4): $135-138$. 
GRASS, I.B. e A.J. MACKENZIE, 1972. Restoring Subsurface Drain Performance. Journal of the Irrigation and Drainage Divi sion. New York, 98 (IR 1): 97-106.

GULATI, O.P.; G.O. SCHWAB E R.C. REEVE, 1970. Control of Se diment Flow into Subsurface Drains. Journal of the Irrigation and Drainage Division, New York, 96 (IR 4): 437-449. HOLANDA. Ministerie van Landbouw en Visserij, 1984. Evolução das Técnicas de Drenagem Subterrānea. Gazetilha Agrí cola dos Países Baixos. Den Haag, 4 : 1-5.

LUTHIN, J.N.; G.S. TAYLOR e C. PRIETO, 1968. Exit Gradients into Subsurface Drains. Hilgardia, Berkeley. 39 (15): 419-428.

MACKENZIE, A.J. 1962. Chemical Treatment of Mineral Deposits in Drain Tile. J. Soil and Water Cons. Beltimore. $17(3): 124-125$

MILLAR, A.A., 1978. Drenagem de Terras Agricolas: Bases Agro nômicas. São Paulo, McGraw-Hill. 276p.

PIZARRO, F., 1975. Materiales de drenaje subterraneo: teoria, practica y criterios de eleccion. In: III Seminärio Nacional de Irrigação e Drenagem, Fortaleza. MINTER/DNOCS -ABID, p. 108-124.

RAADSMA, S., 1974. Current Draining Practice in Flat Areas of Humid Regions in Europe. In: SCHILFGAARDE, J.V., Ed. Drainage for Agriculture. Madison, American Society of Agronomy, P. 115-140 (Série Agronomy, 17). 
SAMANI, Z.A. E WILLARDSON, 1981. Soil Hidraulic stability in a Subsurface Drainage System. Trans. Am. Soc.agric.Engrs. st. Joseph, 24 (3): $: 666-669$.

SÃO PAULO. Instituto de Pesquisas Tecnológicas, 1975. Bidim Ensaios de Permeabilidade e Colmatação. São paulo. $34 \mathrm{p}$. (Relatórios de no 8108 e 8499).

SAO PAULO. Instituto de Pesquisas Tecnológicas, 1981. Ensai os de Permeabilidade, Colmatação e Inspeção por Microscópio Eletrônico de Varredura, sobre Mantas Geotéxteis e En saios Comparativos com Areia. São Paulo. 55p. (Relatório no 14339)

SERAPHIM, L.A., 1982. Aplicação do Geotêxtil na Drenagem Ver tical de Campos Gramados. São Carlos, EESC/USP, 212 p. (Tese de Doutoramento).

SILVA, L.M., 1983. Envelopamento de Tubos-Dreno com Mantas Não tecidas. Florianópolis, Imprensa Universitária-UFSC. $118 \mathrm{p}$

SOMMERFELDT, T.G., 1975. Outflow from Various subsurface Dra inage Materials. Trans.Am.Soc.agric.Engrs.. St. Joseph, 18()$: 85-88,95$.

SUTTON, J.G., 1952. Maintaining Drainage Systems. Washington, D.C., U.S. Dept. of Agric. 30p. (Farmer's . Bulletin n! 2047). 
VARGAS, M., 1978. Introdução à Mecânica dos Solos. São Pau 10, McGraw-Hill. 509p.

WESSELING, J. e F. HOMMA, 1967. Entrance Resistance of Plas tic Drain Tubes. Neth.J.Agr.Sci. Wageningen, 15: 170-182. WILLARDSON, L.S.; J.I. FOUSS; R.C. REEVE e N.C. FAUSEY, 1968. Entry Velocity Control Limits Drain Sedimentation. J.Irrig.Drain.Div. New York, 94 (IR 4): 455-463.

WILLARDSON, L.S., 1974. Envelope Materials. In: SCHILFGAARDE, J.V., Ed. Drainage for Agriculture. Madison, American Society of Agronomy, P. 179-196. (Série Agronomy,17). WILLARDSON, L.S.; S DAVIS; D. MULDER E J.R. SPENCER, 1975. Drain Envelope Response to Field Treatments. Trans.Am. Soc.agric.Engrs. St. Joseph, 18 ( ): 134-136.

WILLARDSON, L.S. e M.J. BATISTA, 1980. Compaction Effects on Hydraulic Failure Gradients. In: EGGLESTON, J., Ed. Irrigation and Drainage Today's Challenges. Boise, J. Irrig.Div.Am.Soc.civ.Engrs., p. 141-149. 
76.

$\underline{A} \underline{\mathrm{P}} \underline{\mathrm{N}} \mathrm{D} I \underline{\mathrm{C}} \underline{\mathrm{E}}$ 


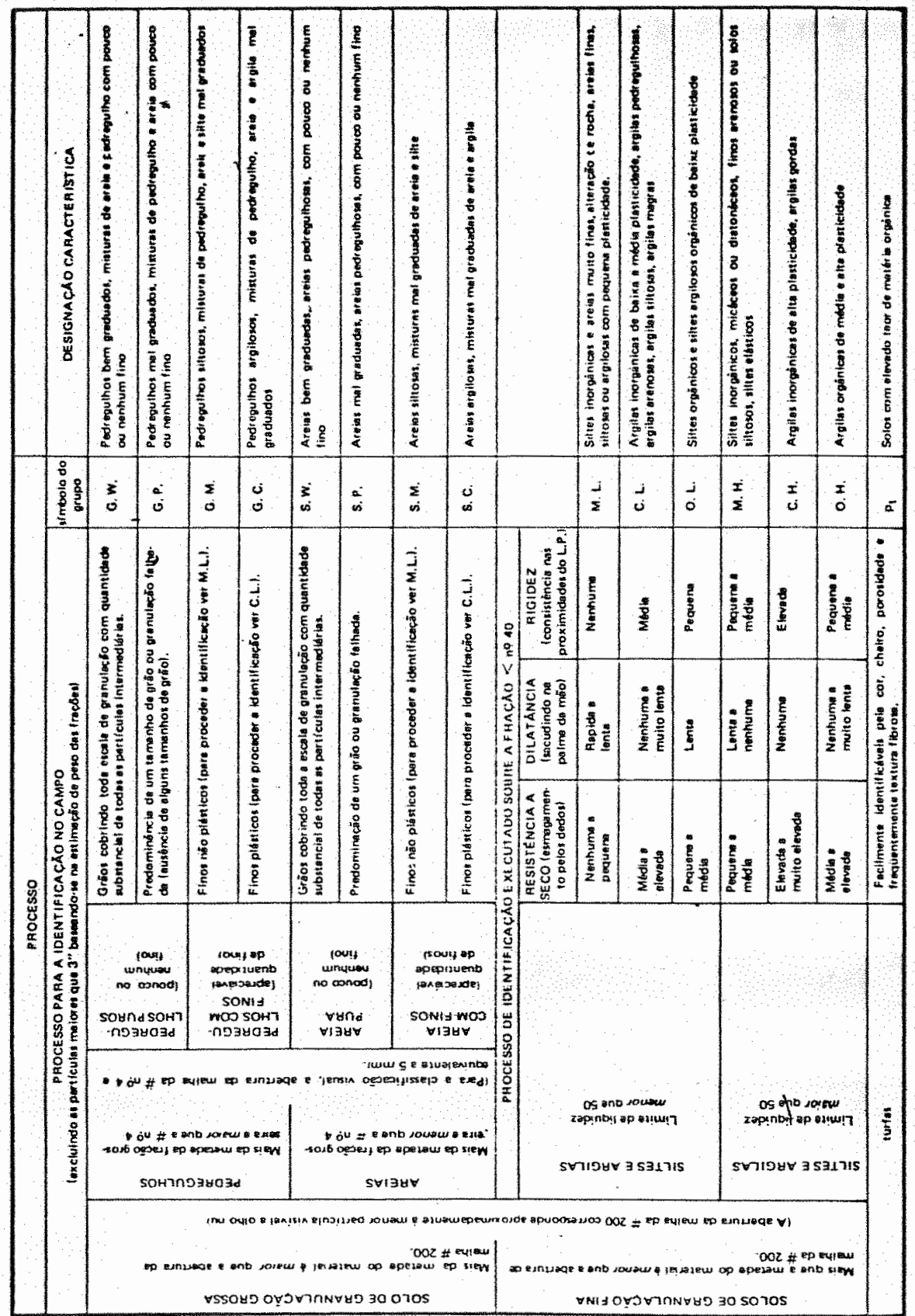


$\underline{A} \underline{P} \underline{E} \underline{N} \underline{\mathrm{I}} \underline{\mathrm{E}} \underline{\mathrm{II}}$ 
79.

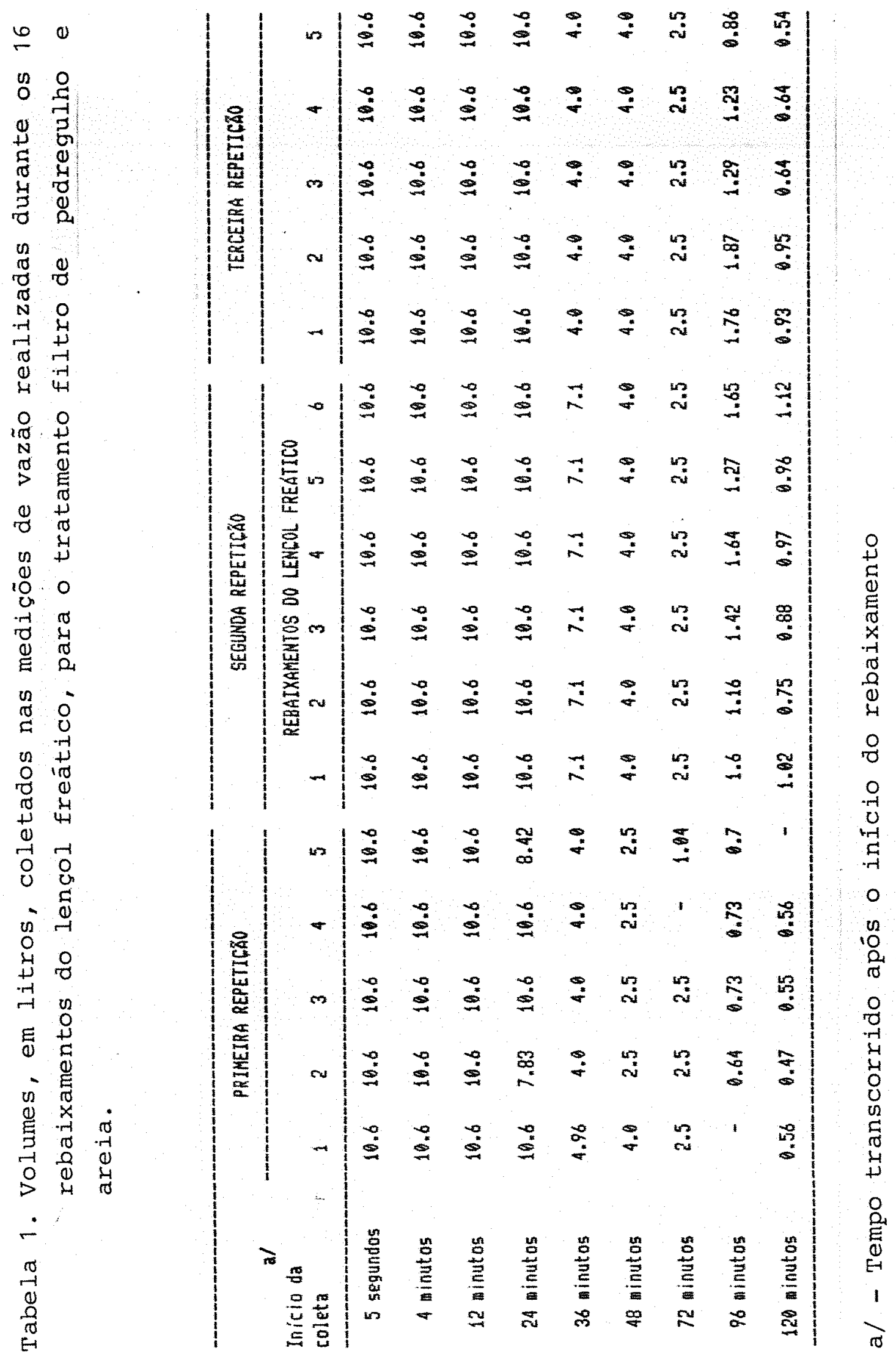


80 .

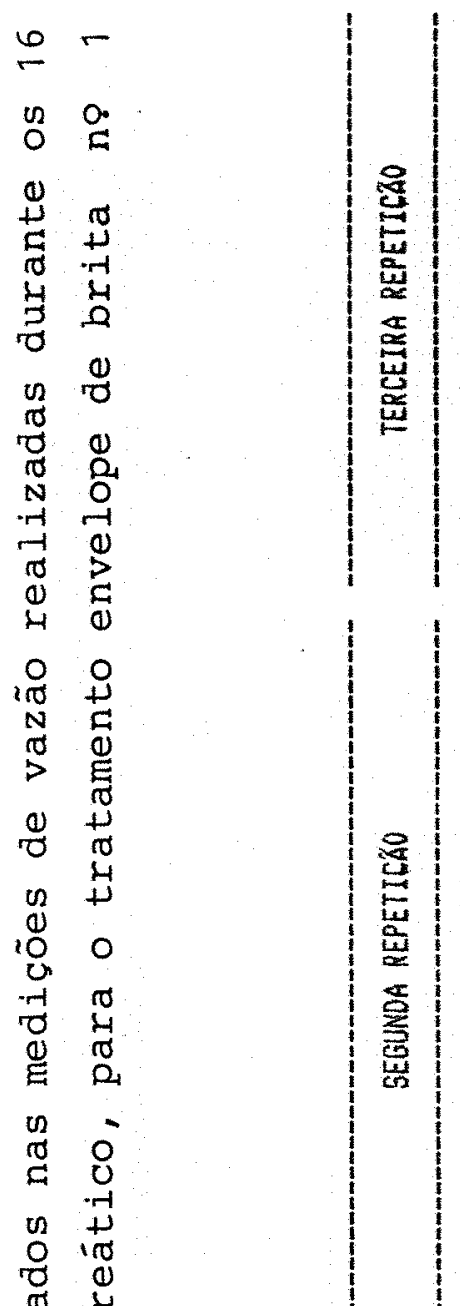

$+4$

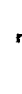

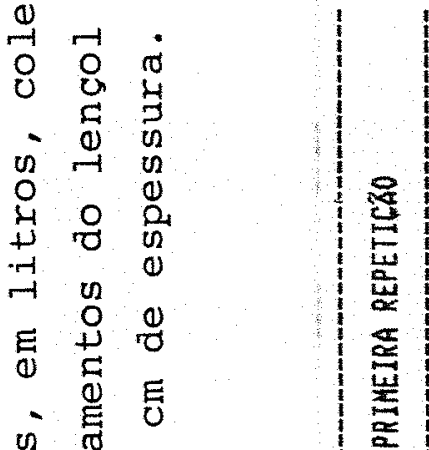

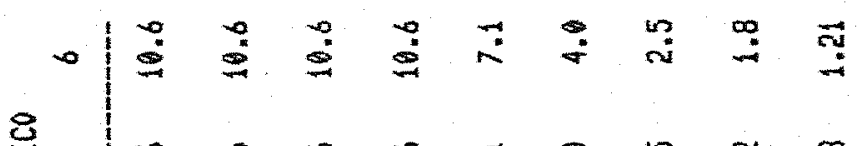

崫的

宮

品

到

(1)

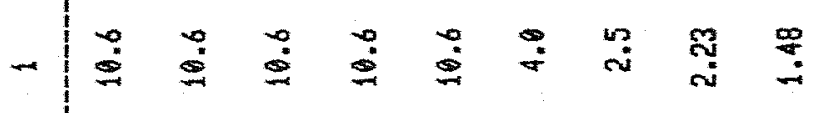

웅

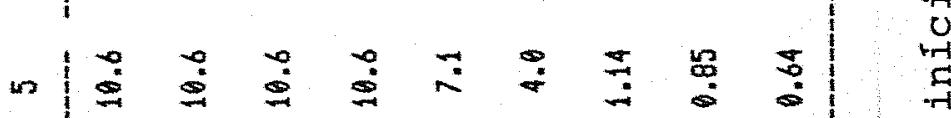

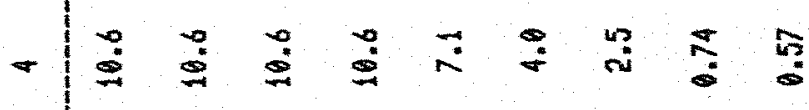

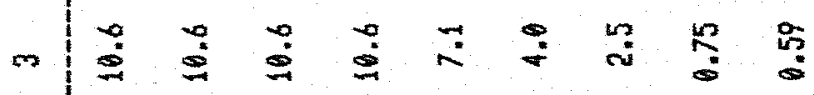

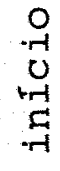

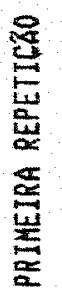

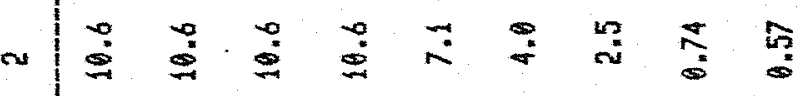

$-\mid \begin{array}{lllllllll}0 & 0 & 0 & 0 & 0 & 0 & 0 & 0 & 0\end{array}$

0
10
0
0

() $\times 0$

है

$\begin{array}{lll}3 & 0 & \\ 0 & 0 & 0 \\ 0 & 0\end{array}$

i

$\frac{\pi}{\infty}$

告

믐

0
0
-1
4
0
0
0
0
0
0
4
+
0
0
0
0
0
1

7 
81.

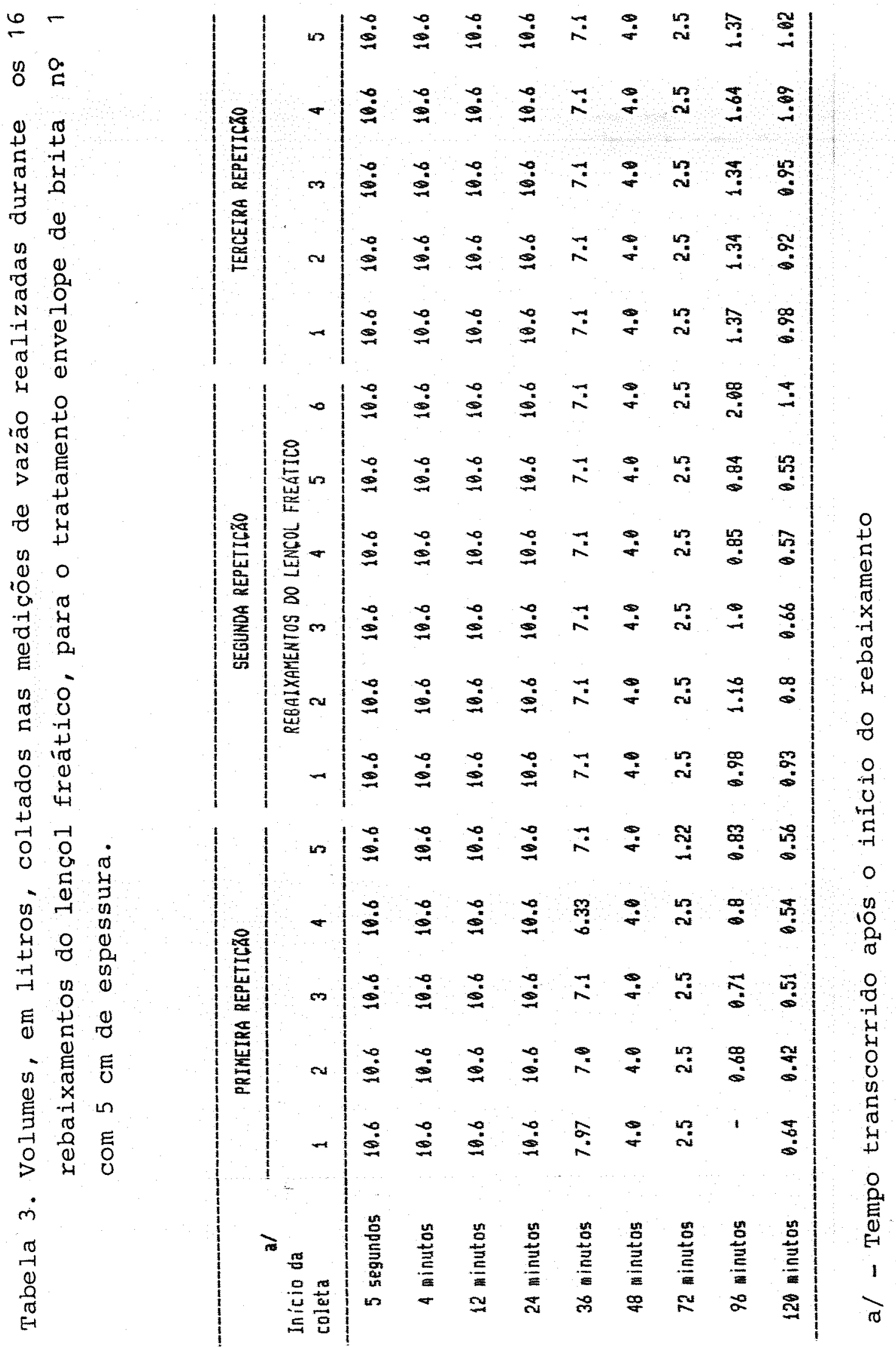


82.

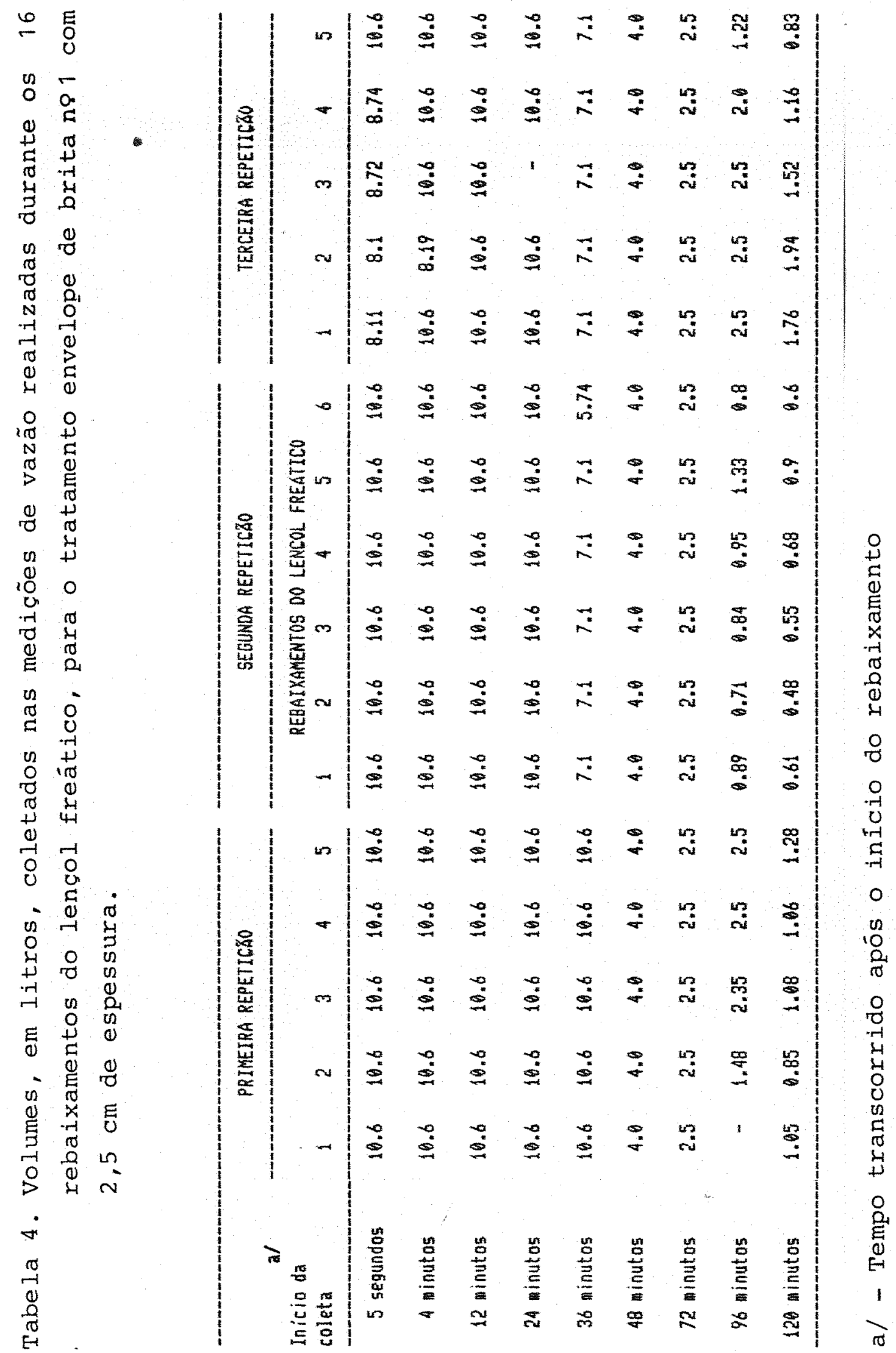




$\circ$

$\begin{array}{cc}0 & 0 \\ N & + \\ 0 & 0 \\ 0 & 0 \\ 0 & 0 \\ 0 & + \\ 0 & 0 \\ 0 & 4 \\ 0 & +\end{array}$

io 0

r

造

(n)

in

\%

$+4$

$\stackrel{1}{-1}$

80

in $\stackrel{0}{-1}$

o

ס

$\rightarrow \begin{gathered}n \\ \text { E } \\ 0\end{gathered}$

(ब)

in

足

$>0$

in

告

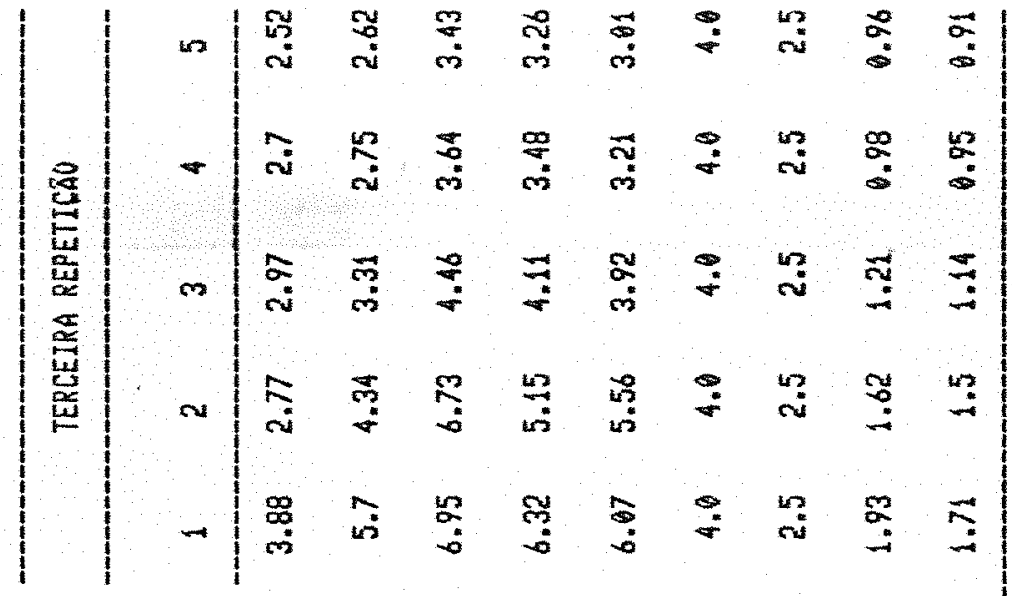

|

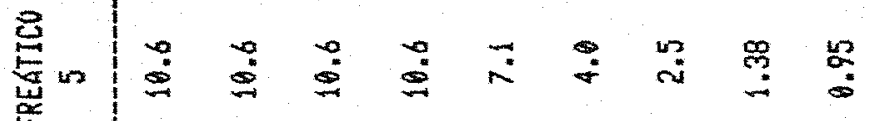

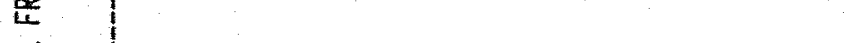

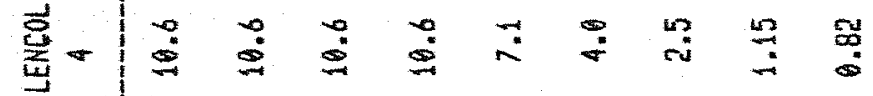

残

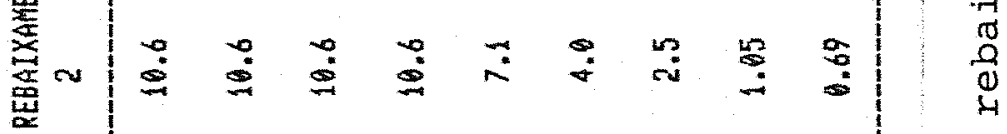

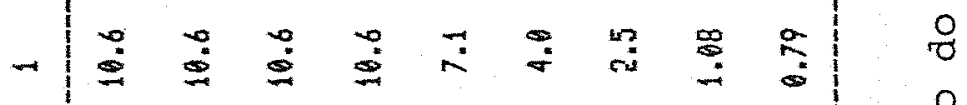

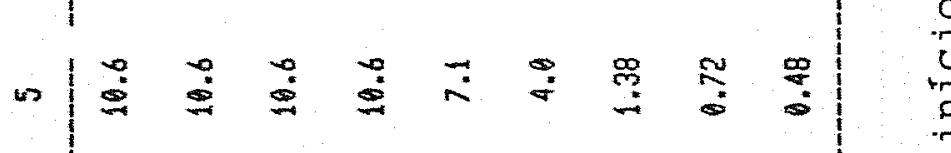

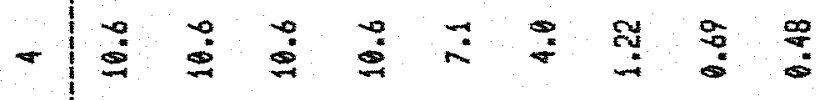

-

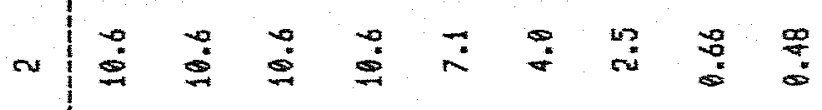

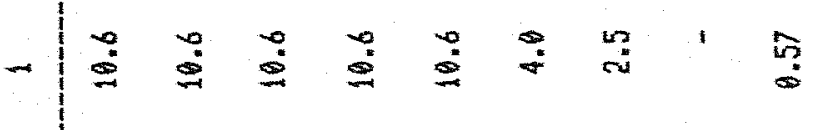

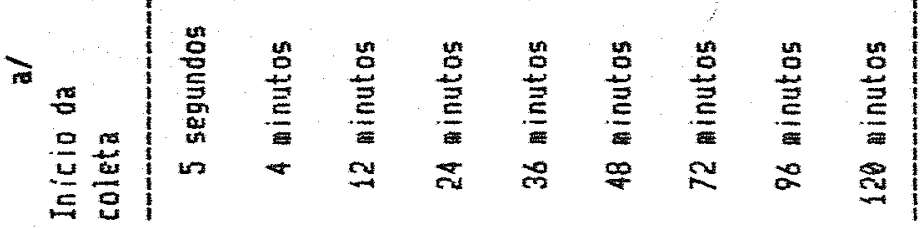

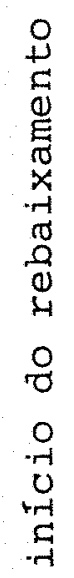

in

8

.7

4
0
0
0

:

岁

总

1 


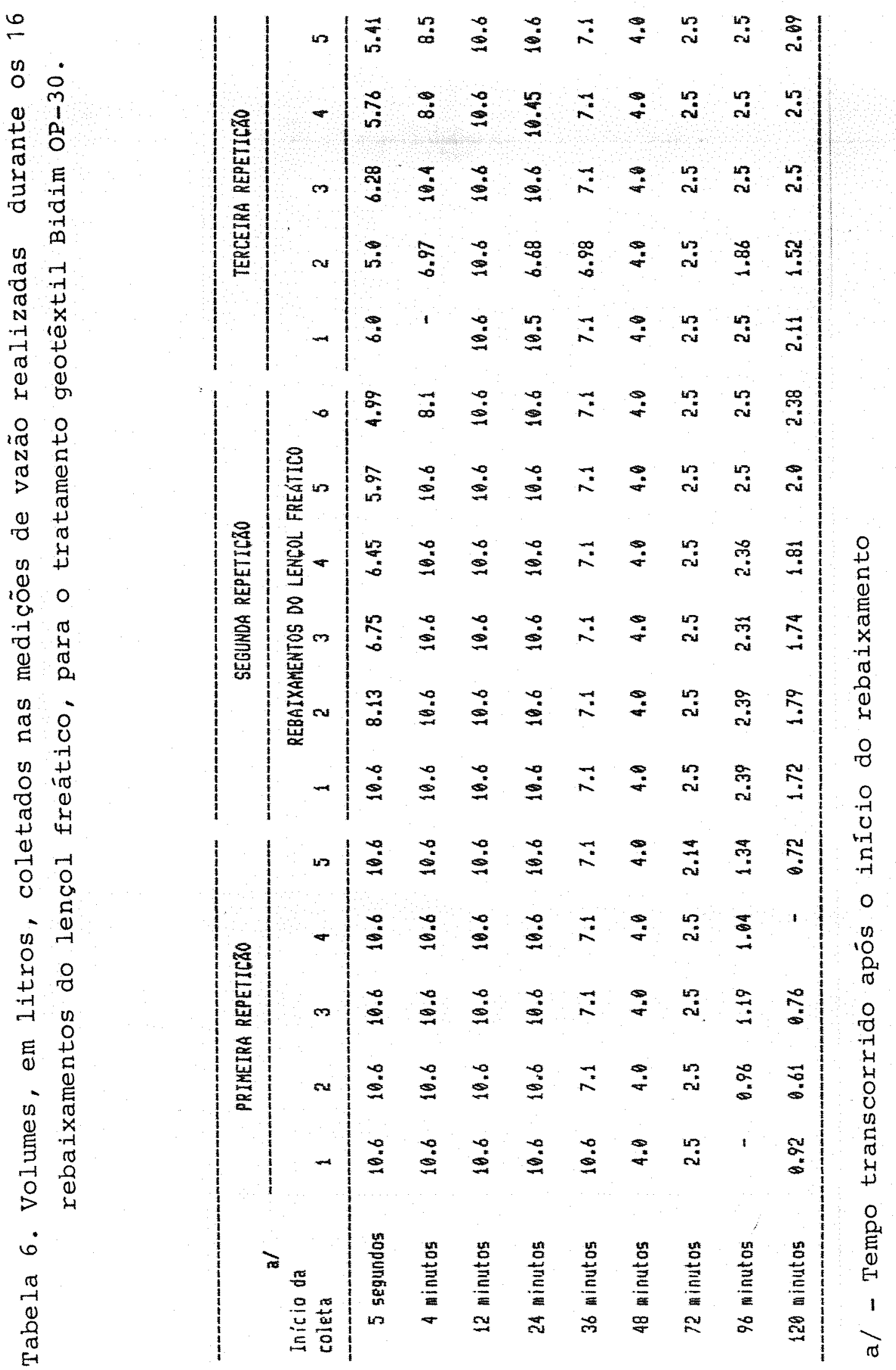


6

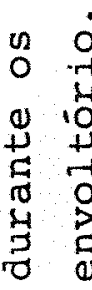

on

$\pi$

N 0

न

嵌

10

$N$

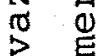

(4)

o 4

O

न्म

总

$\begin{array}{cc}0 \\ 0 \\ 0 & 0 \\ 0 & 0 \\ 0 & 4 \\ 0 & 10 \\ 0 & 0 \\ 0 & 0 \\ 0 & 4 \\ 0 & 4\end{array}$

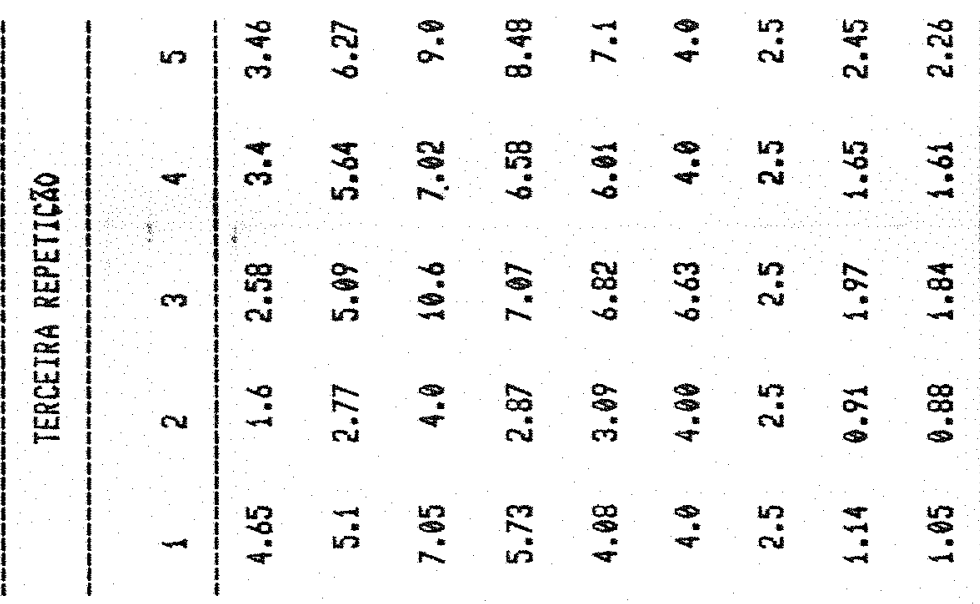

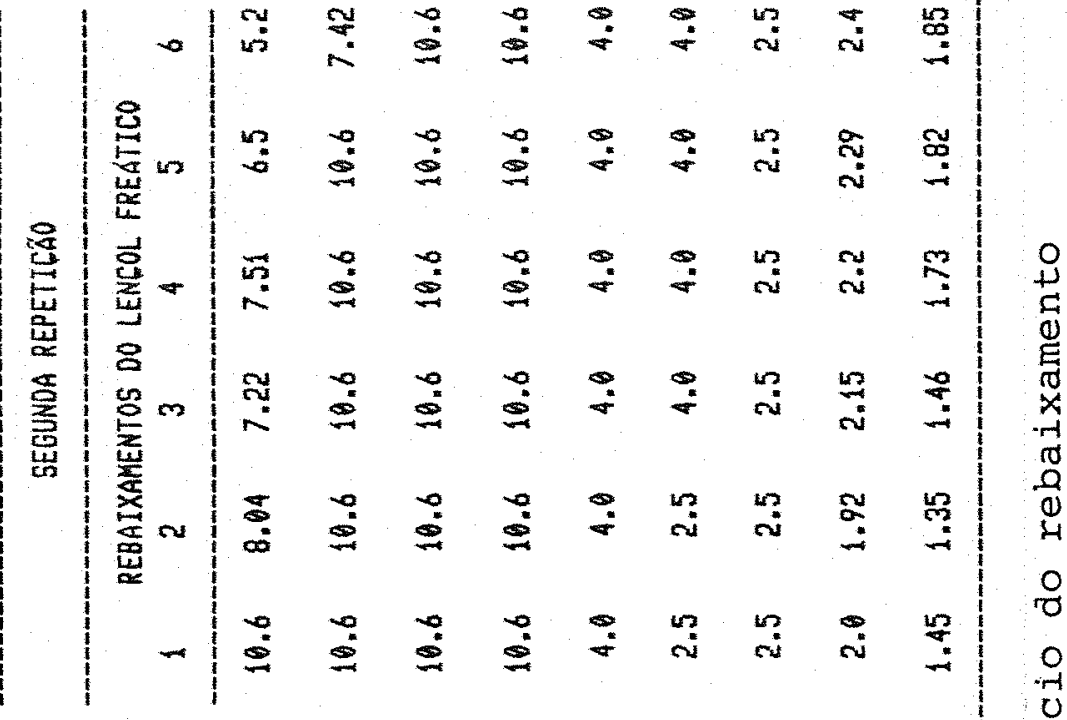

엉 영

in

억

ना

E

a

in

0

音

$\begin{array}{ll}-1 & 0 \\ 0 & 0 \\ >\end{array}$

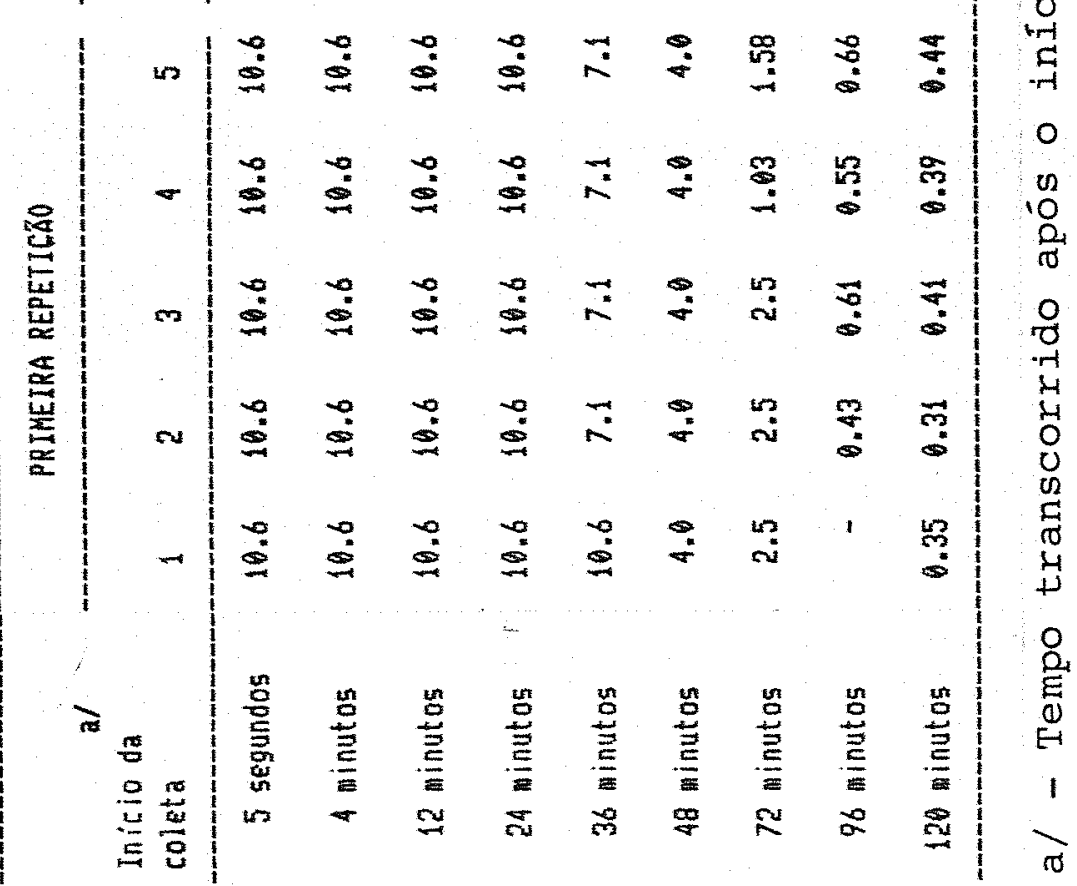




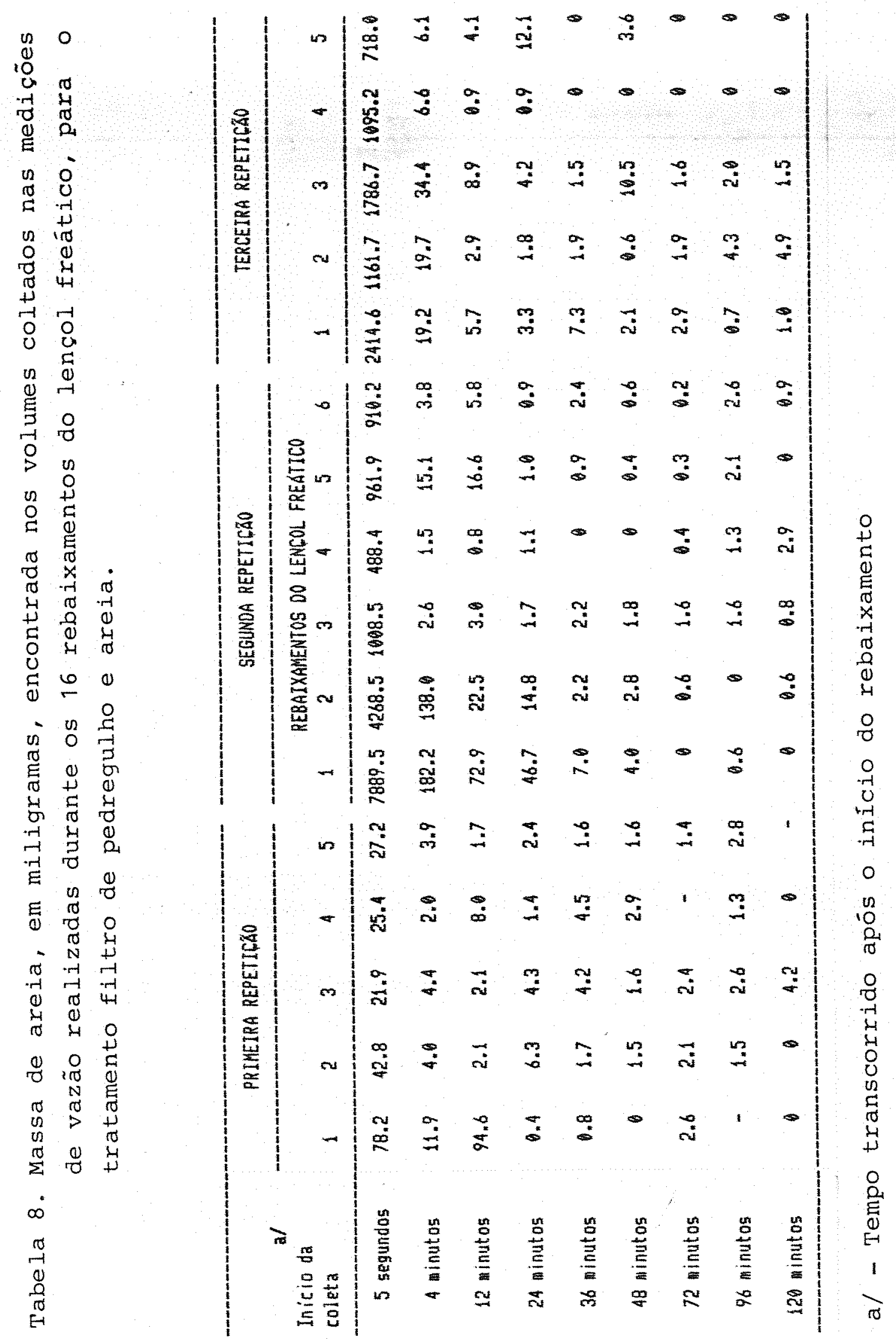


87.

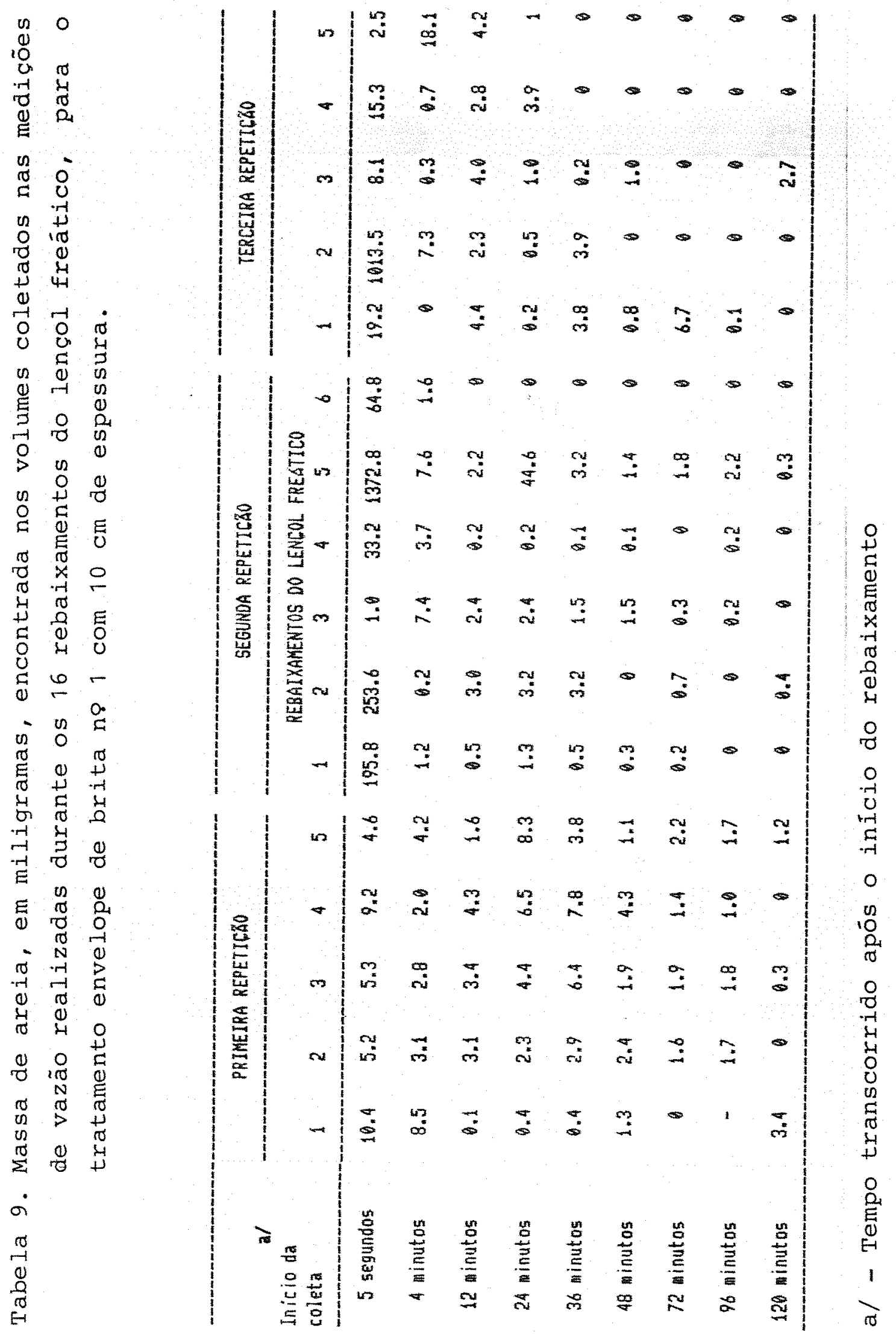




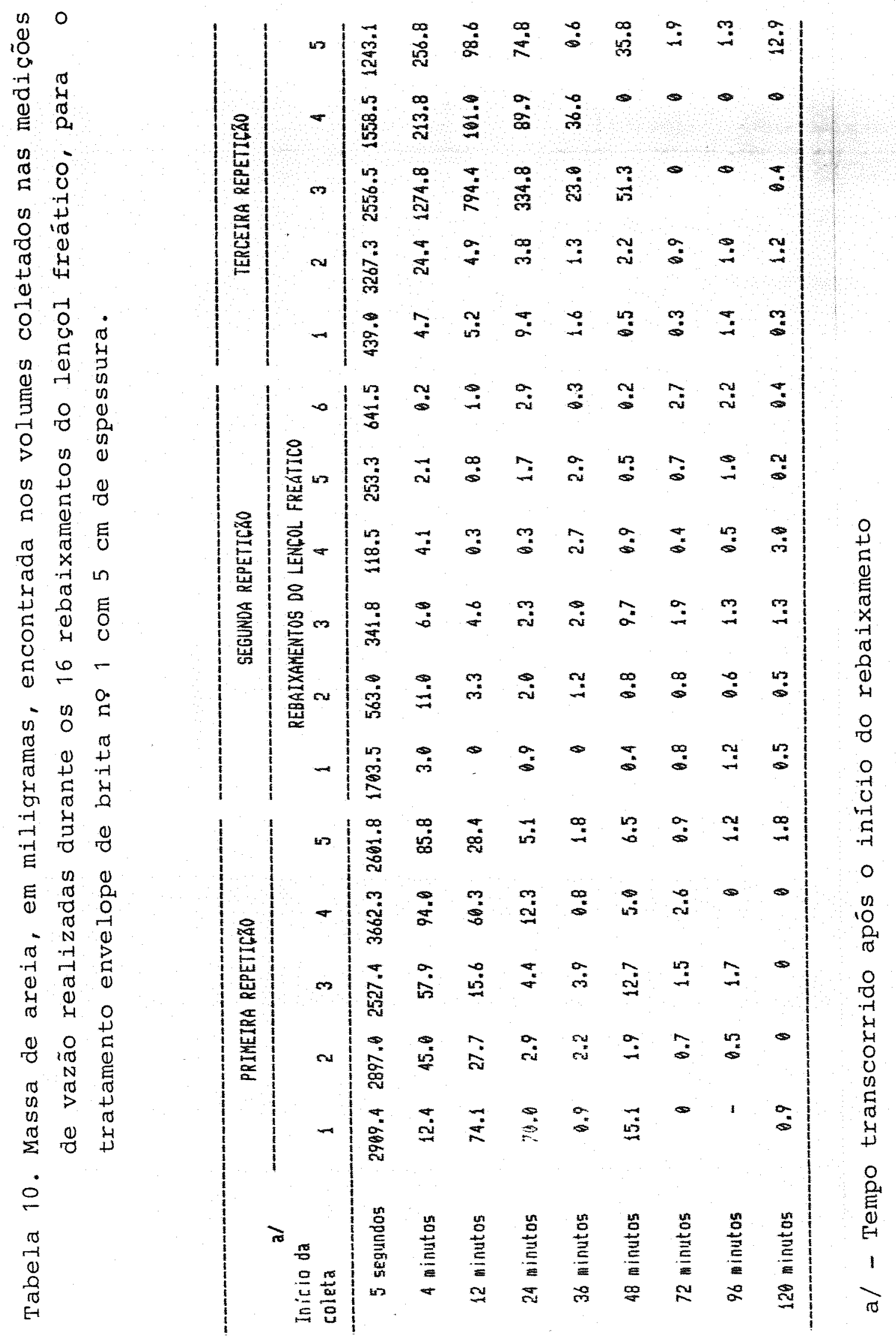




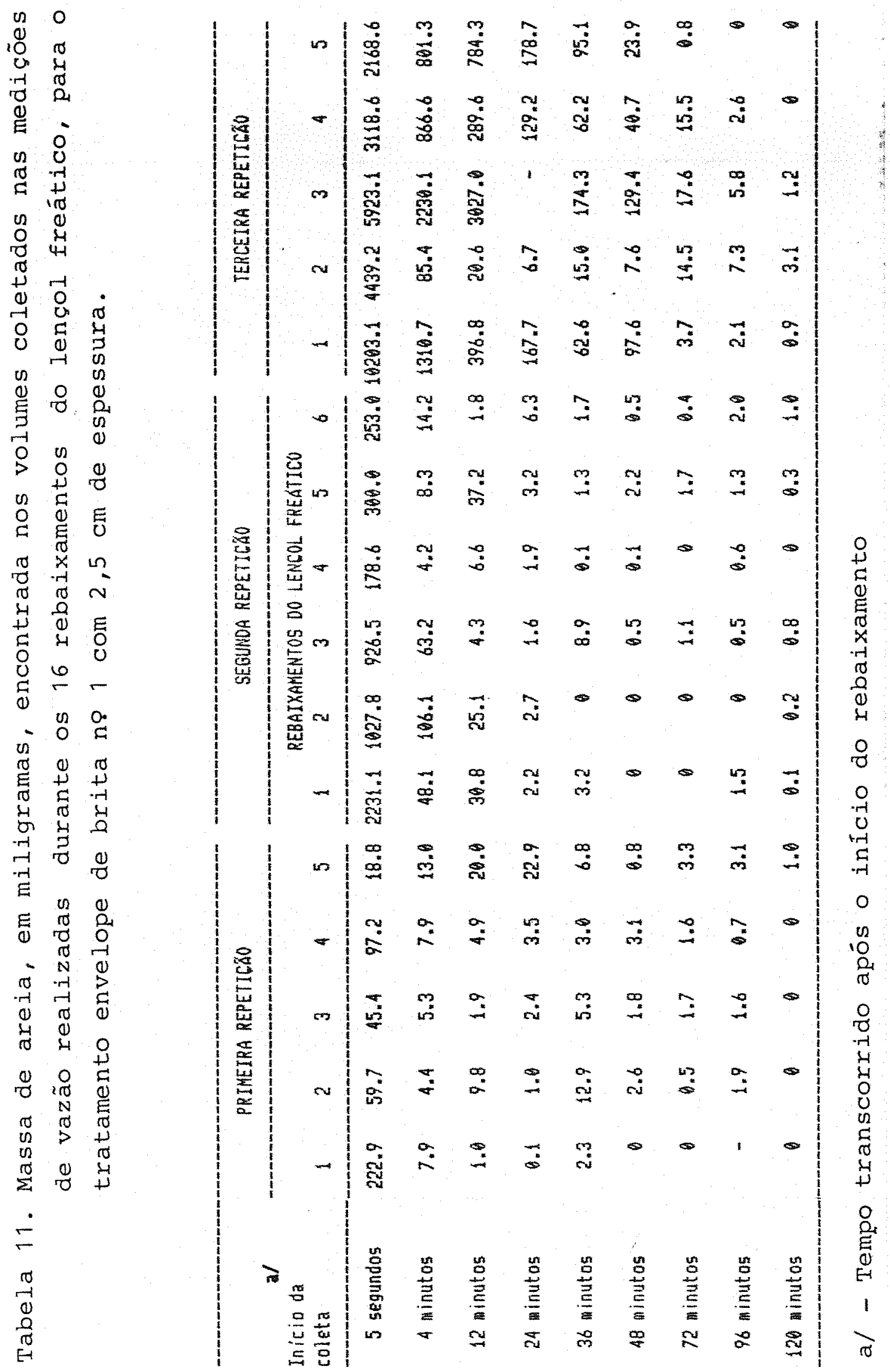


90.

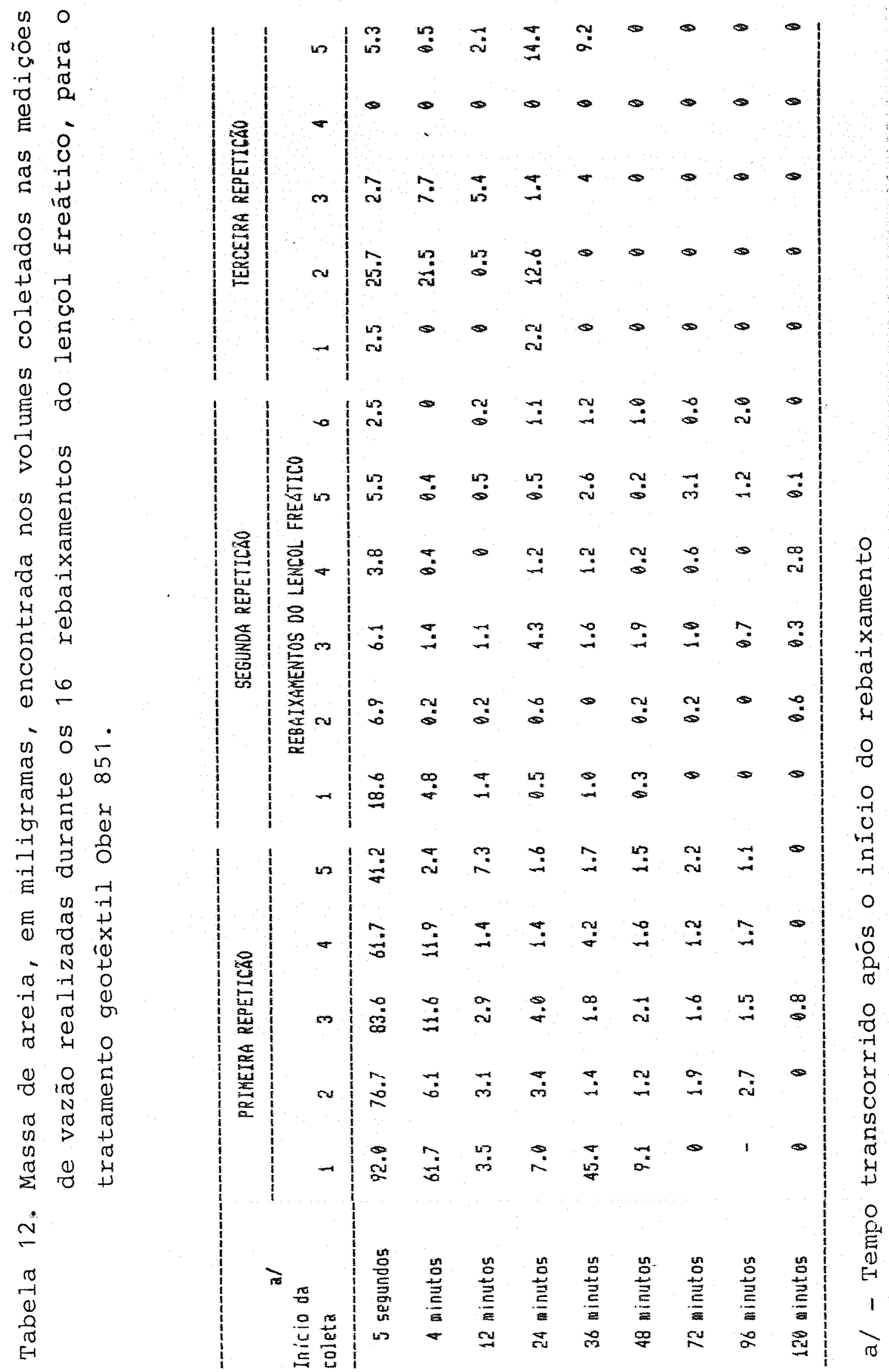




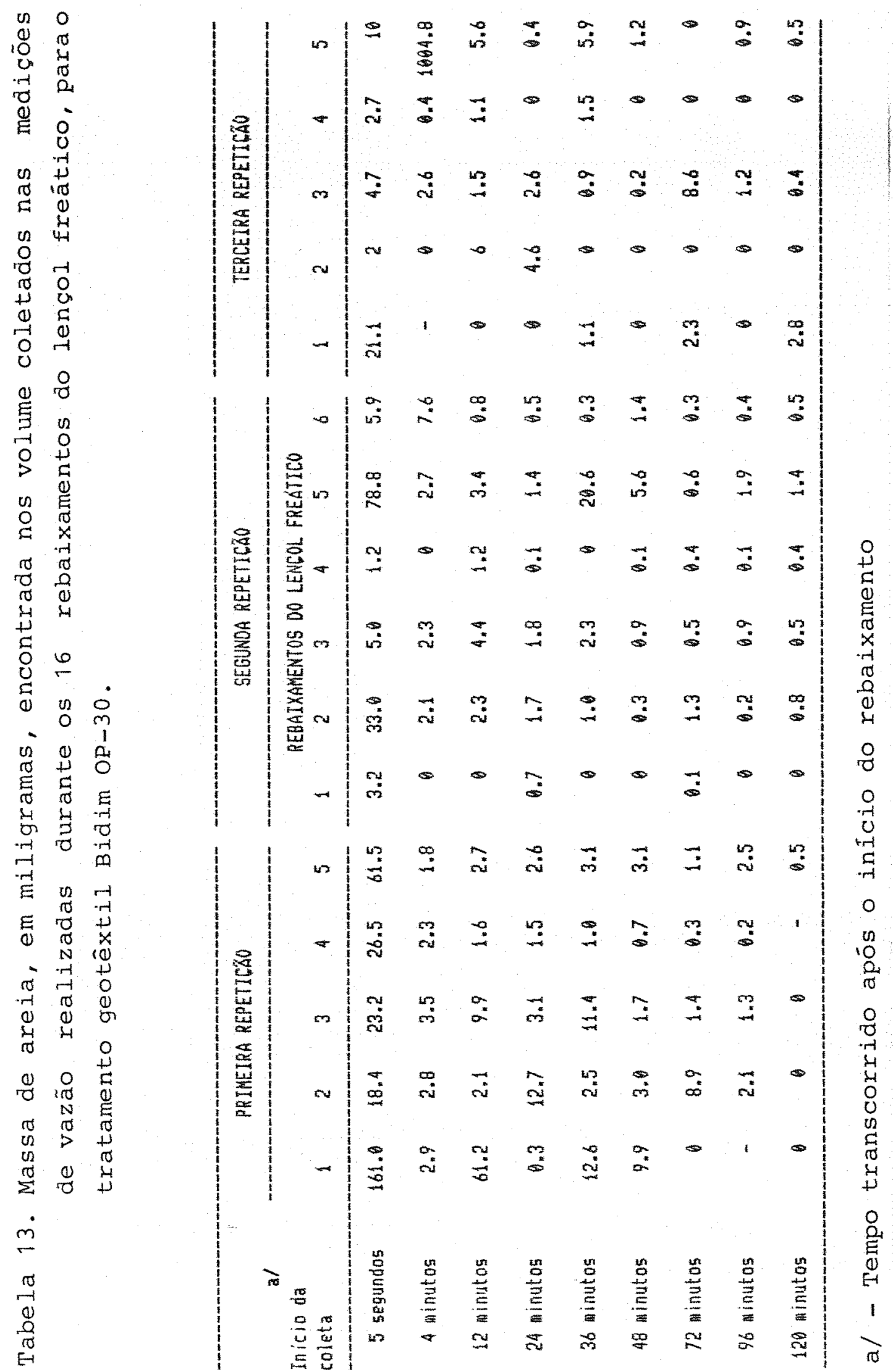




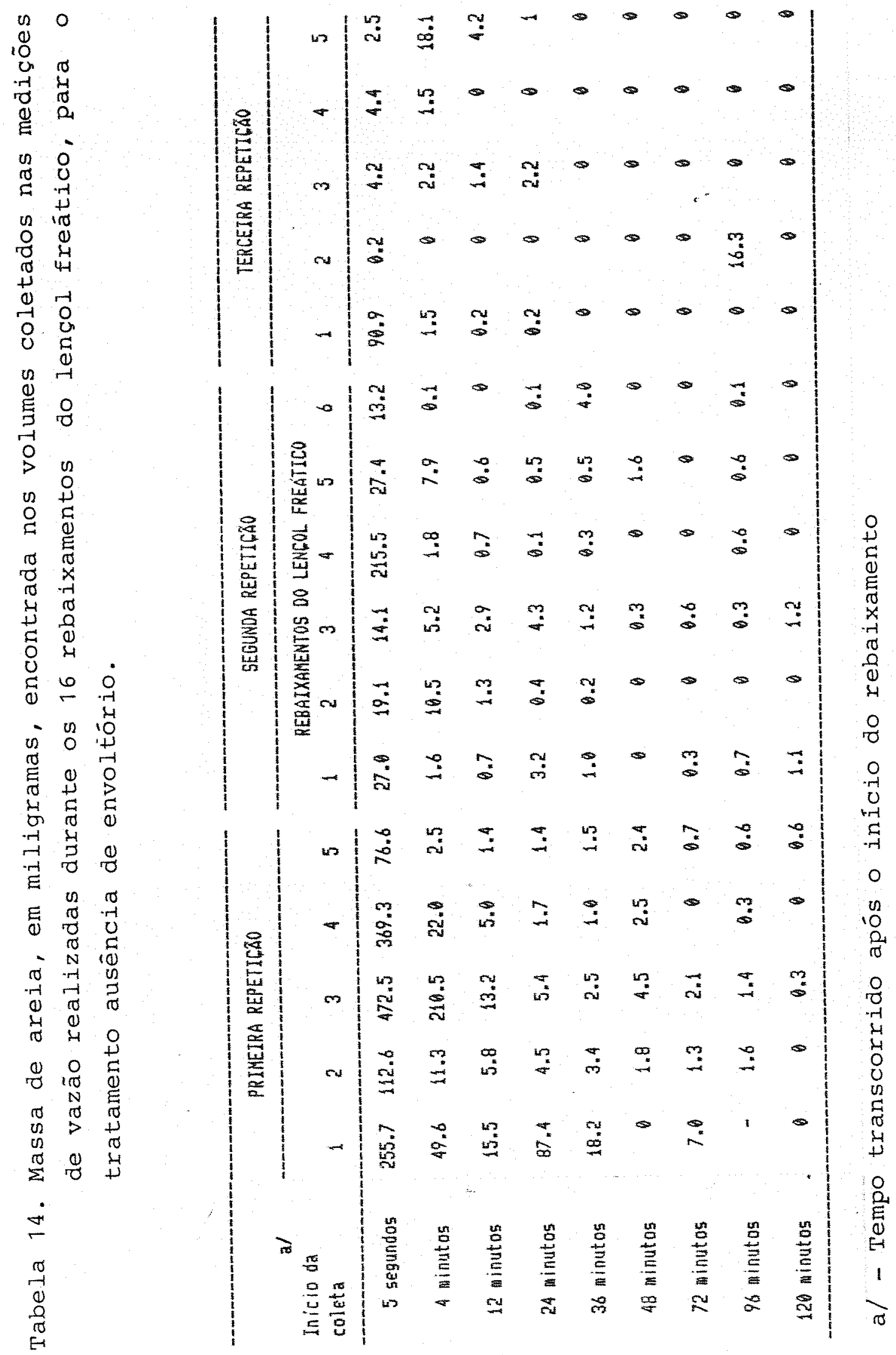




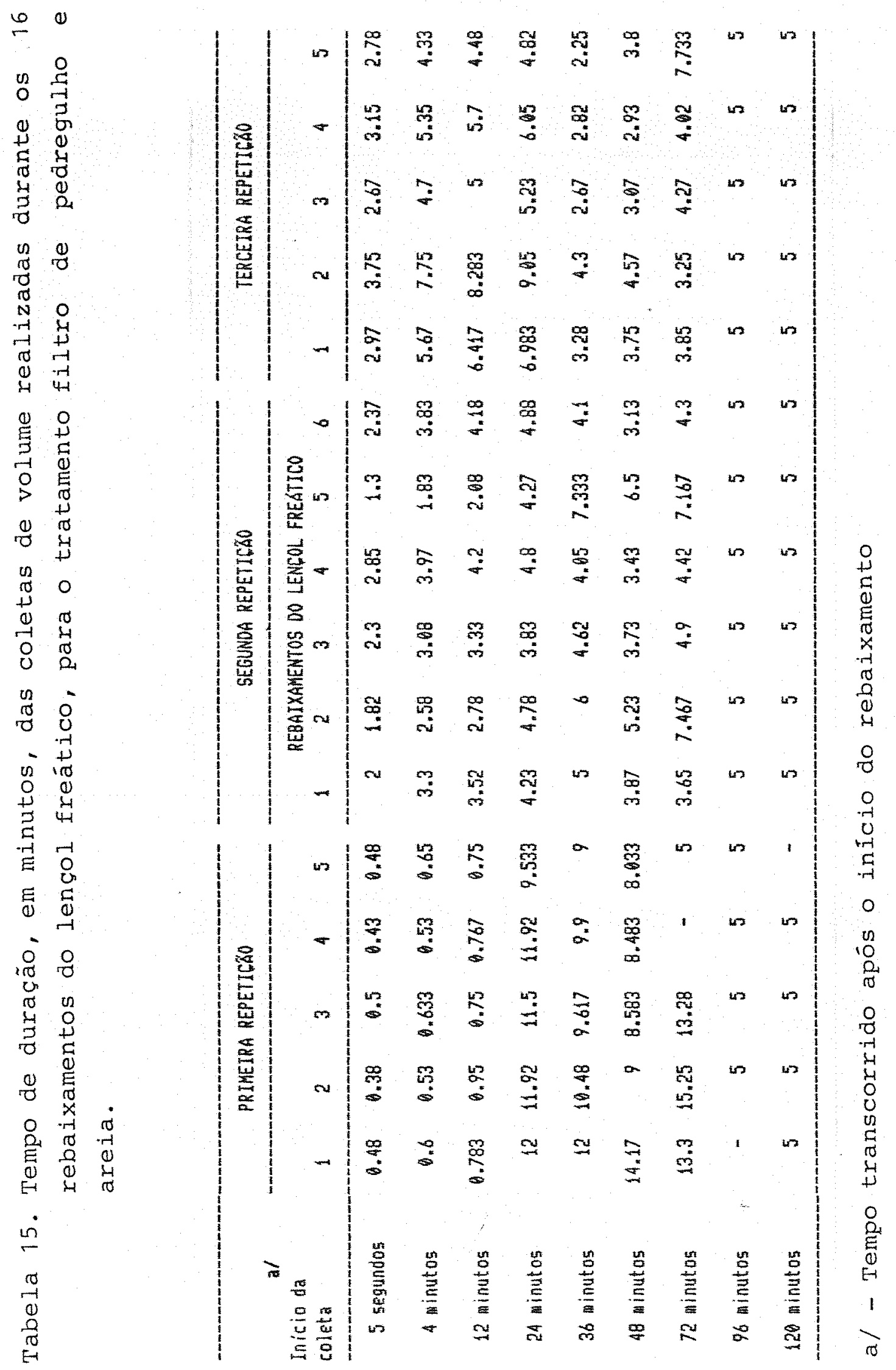




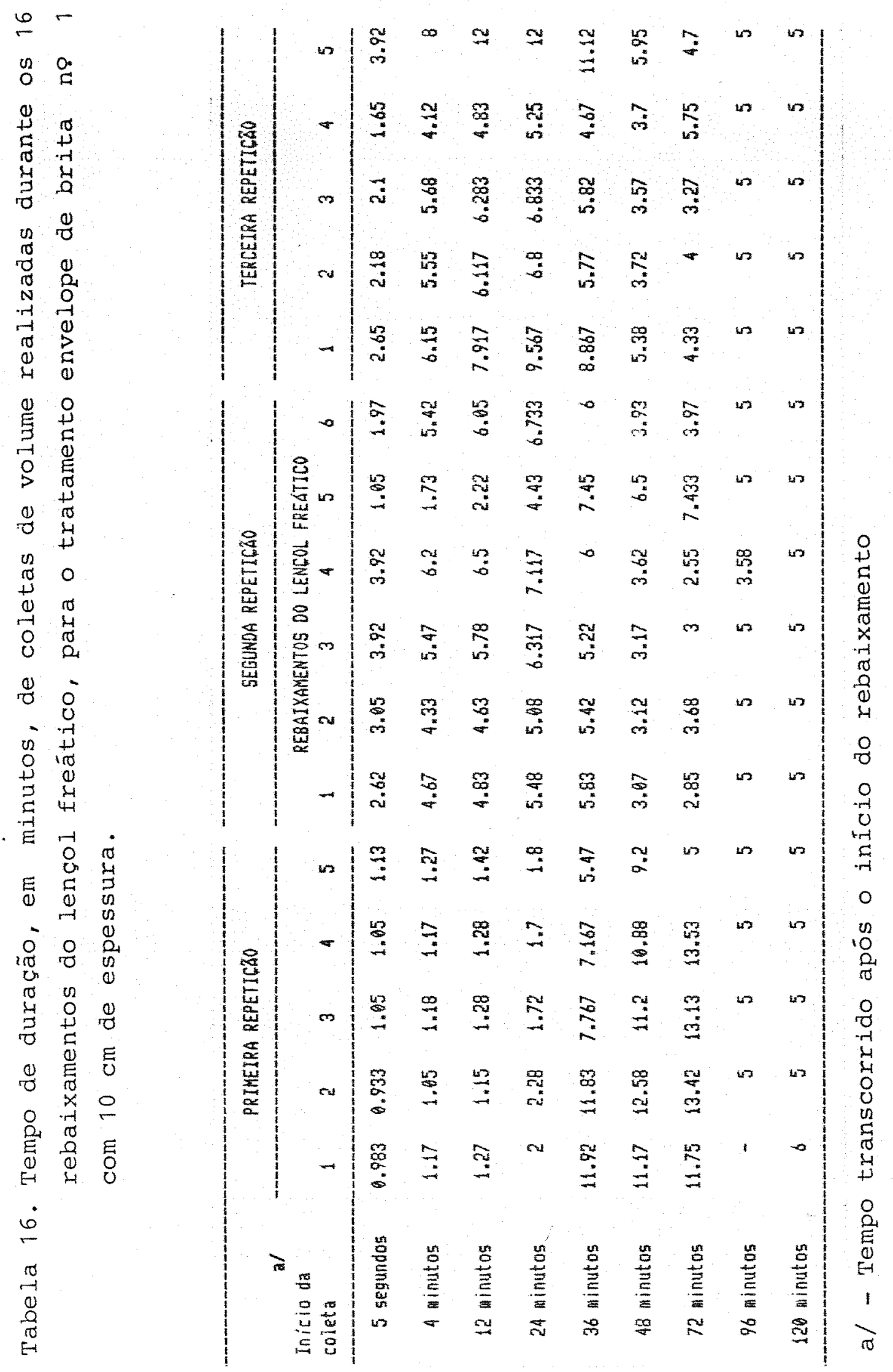




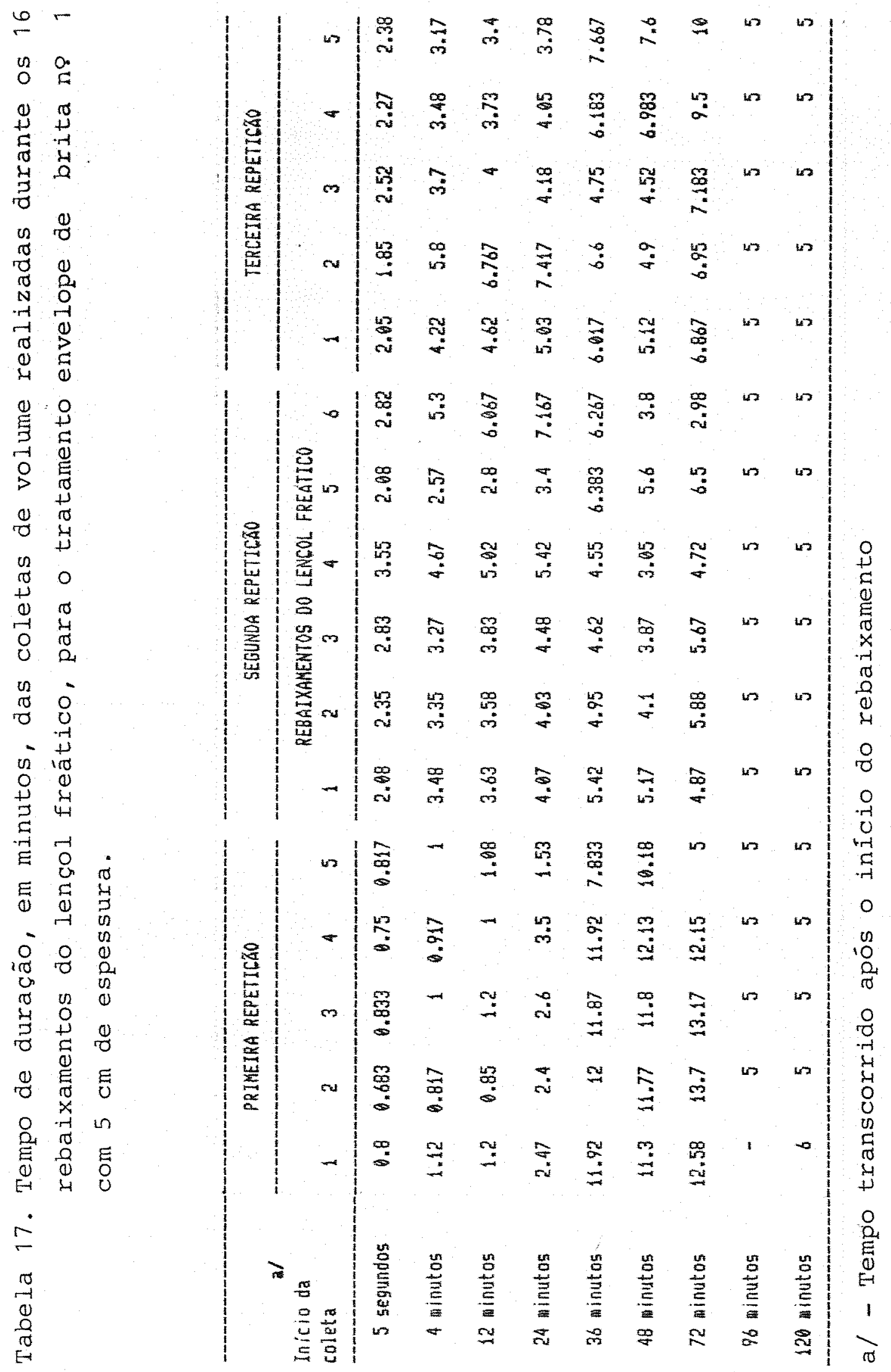


$\div$

in

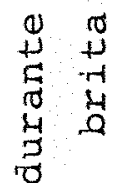

$\begin{array}{ll}0 & 0 \\ 0 & 0 \\ 0 & 0 \\ 0 & 0 \\ 0 & 0 \\ -1 & 0 \\ -1 & 0 \\ \pi & 0 \\ 0 & D \\ 0 & 0\end{array}$

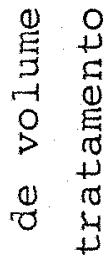

$\begin{array}{lll}0 & 0 \\ 0 & 0 & 0\end{array}$

$\stackrel{+}{\stackrel{0}{\rightarrow-1}}$

$\begin{array}{lll}r & 4 \\ 0 & 0 \\ 0 & 0\end{array}$

$\begin{array}{ll}n & 0 \\ 0 & 0 \\ 0 & 0 \\ & -4 \\ 0 & 4 \\ 0 & 100 \\ 0 & 0 \\ 0 & 4 \\ 3 & 4\end{array}$

$\stackrel{\rightarrow}{-1}$

हE

$\therefore-1 \frac{0}{0}$

i⿱ 000

$\pi$ o 9

岁

Q $\stackrel{0}{E} 0$

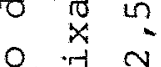

然

$\begin{array}{ccc}E & 0 & E \\ 0 & 0 & 0 \\ \text { E } & \text { H } & 0\end{array}$

$\stackrel{\infty}{\leftarrow}$

$\frac{\sqrt{0}}{0}$

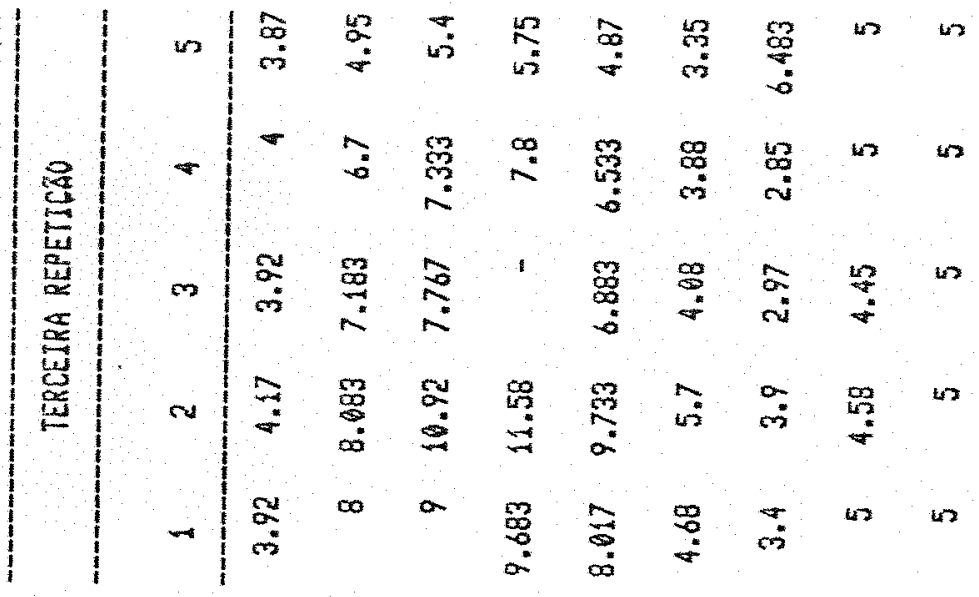

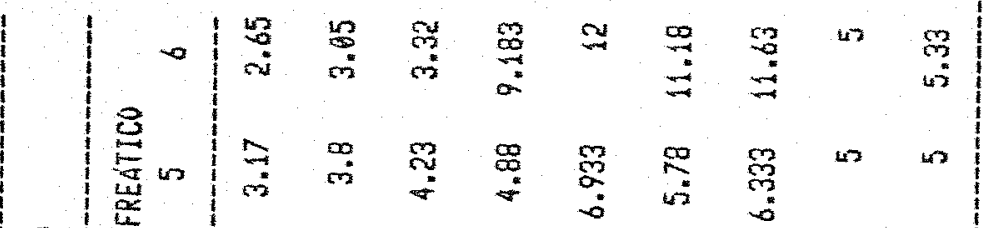

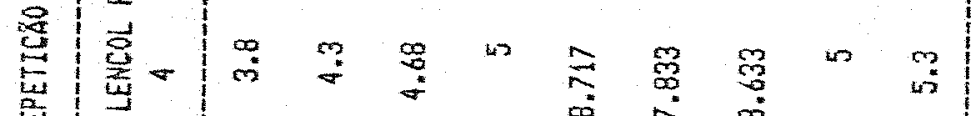

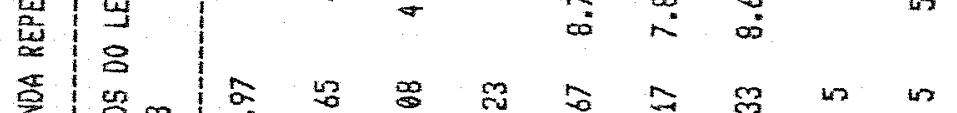

预

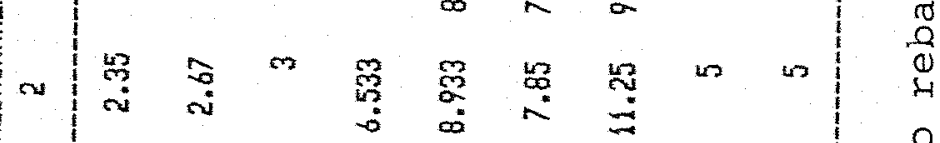

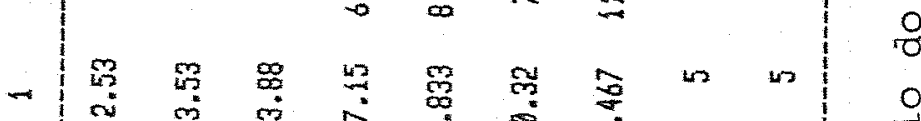

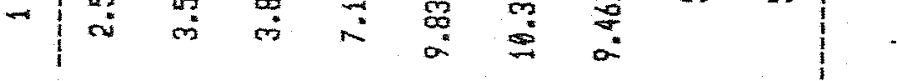

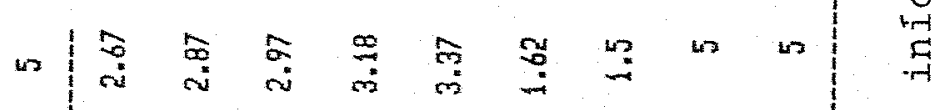

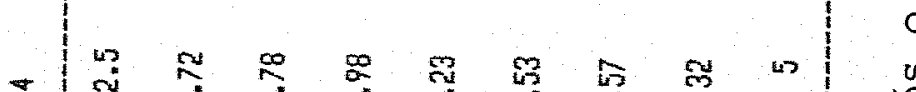

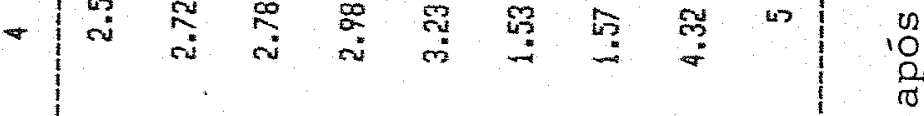

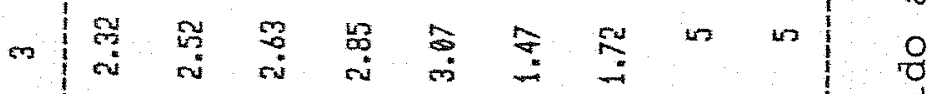

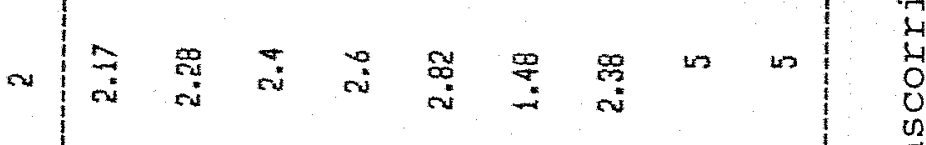

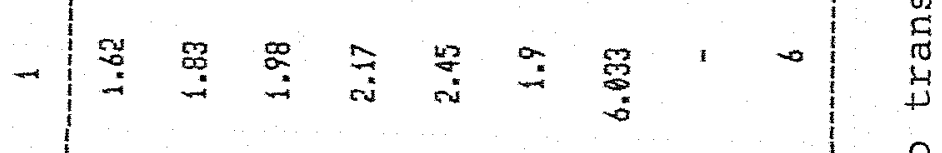

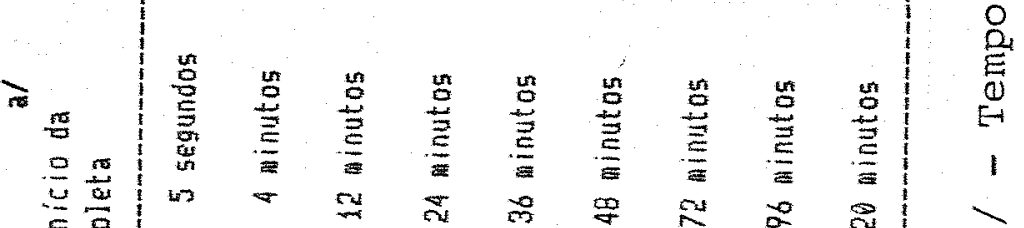
总落 (ช) 


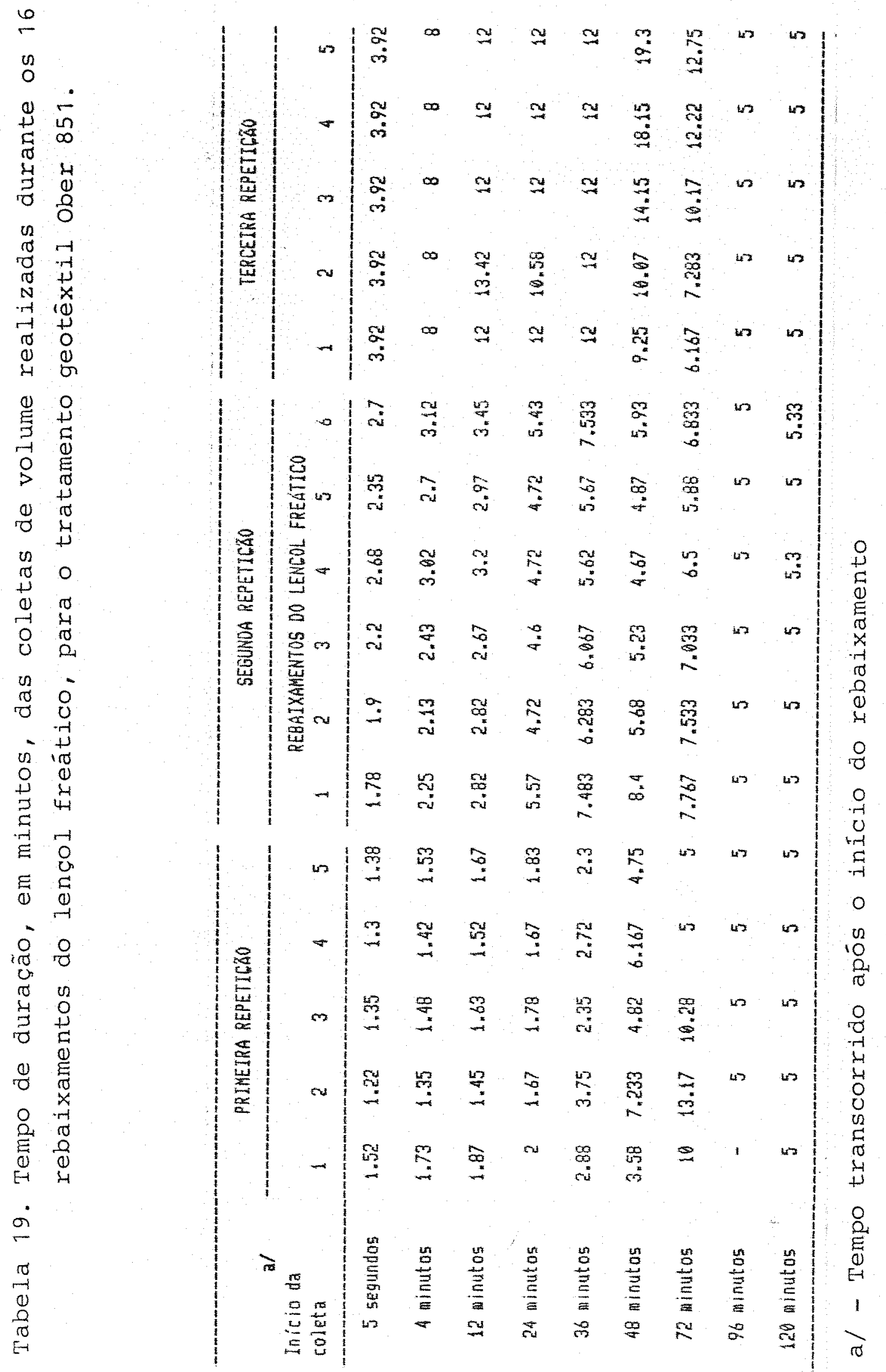


98.

$\stackrel{6}{\circ}$

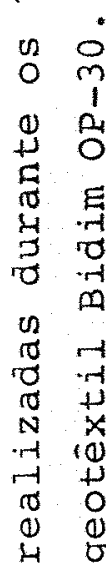

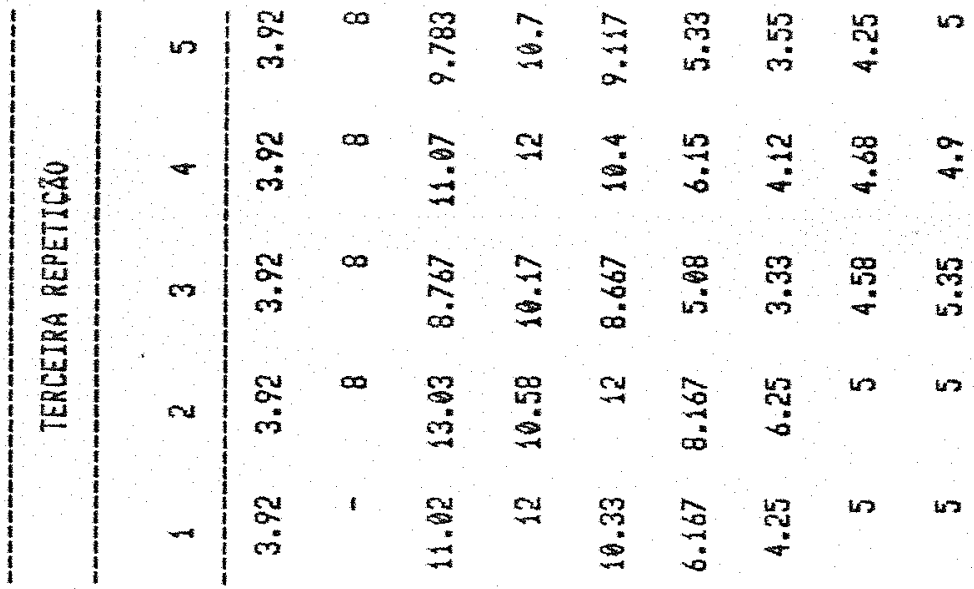

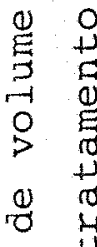

n 0

$\begin{array}{ll}0 & 0 \\ -1 & 4 \\ 0 & 0 \\ 0 & 0\end{array}$

告

is

$\stackrel{0}{+}$

E

E

잉

$\pi$

茪

ठ)

$\circ \quad-4$

怘

道

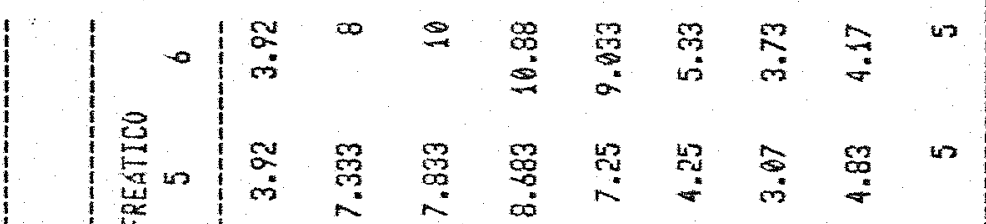

म

焉

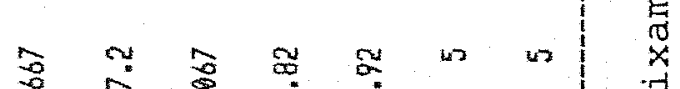

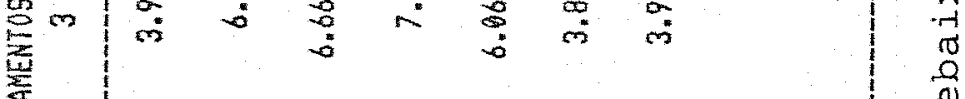

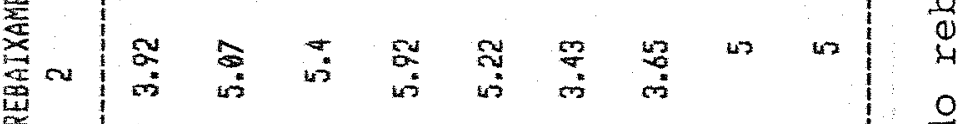

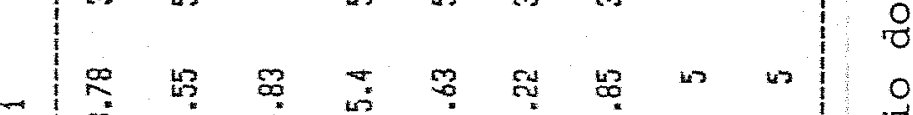

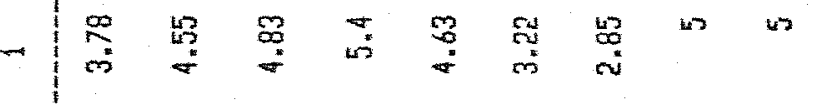

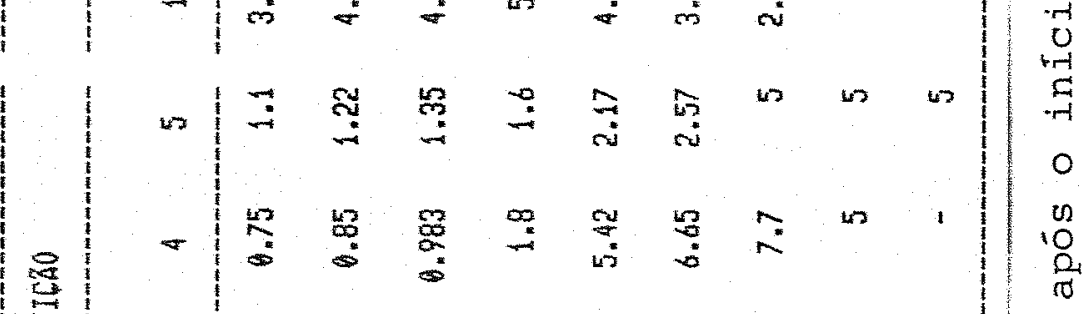

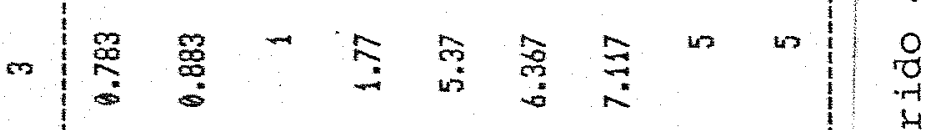

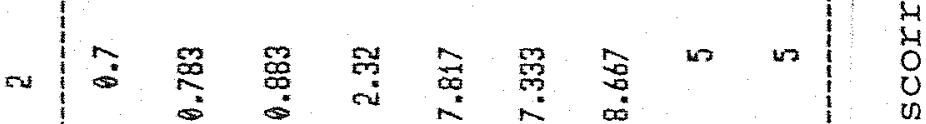

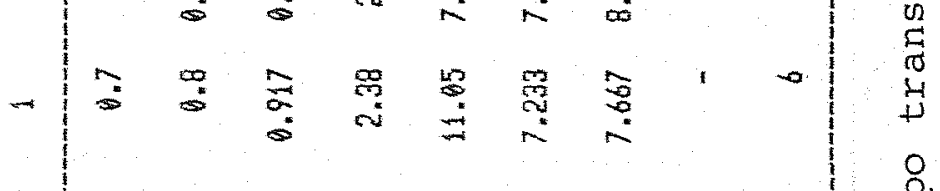

$\stackrel{\dot{\sim}}{ }$

$\int_{\substack{0 \\ 0}}^{0}$

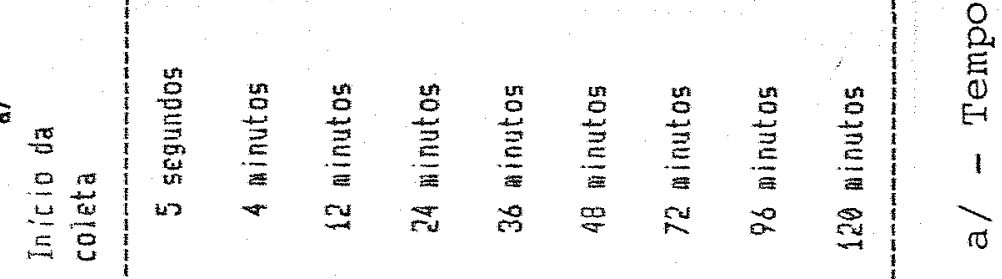




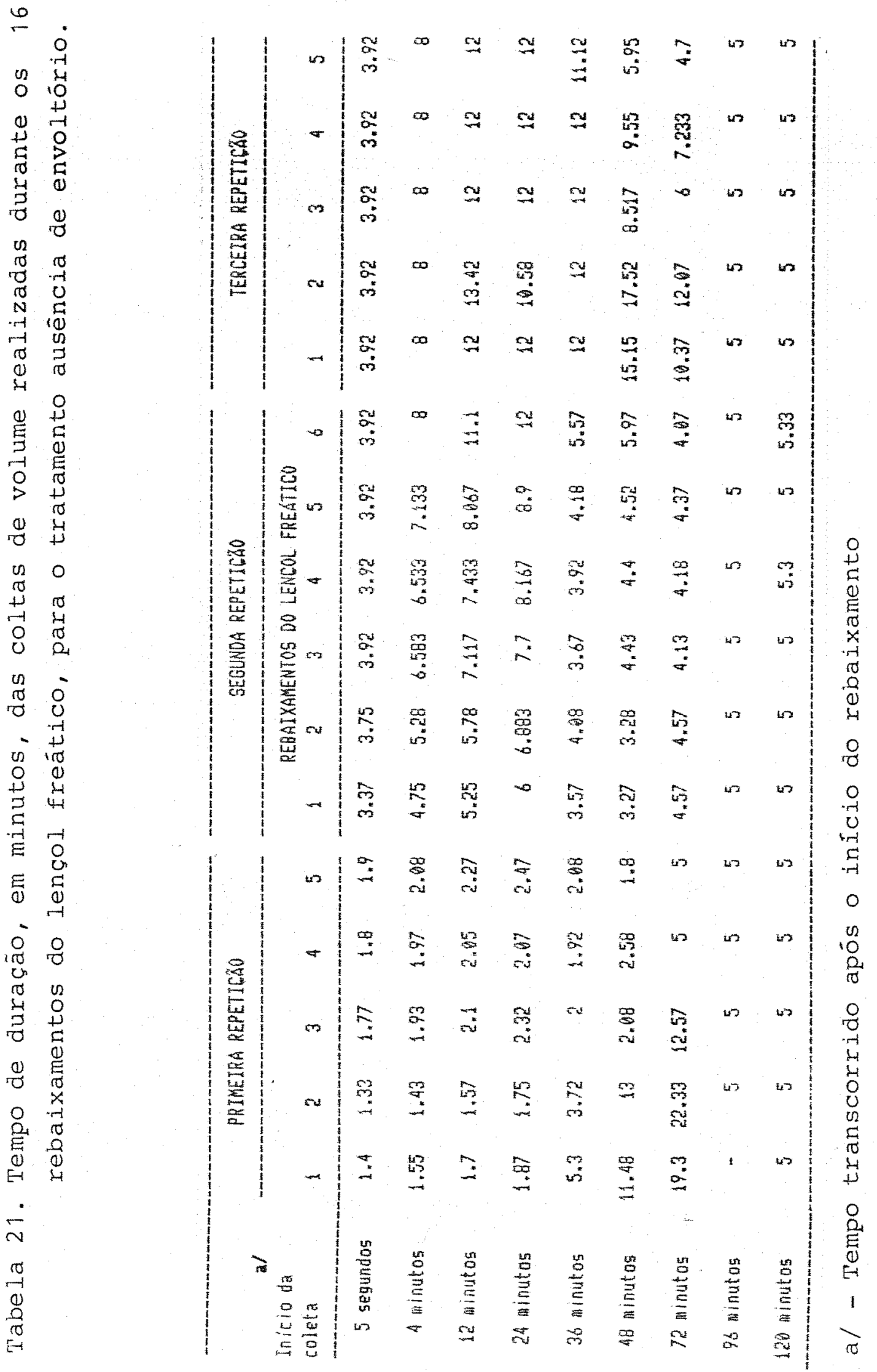




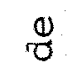

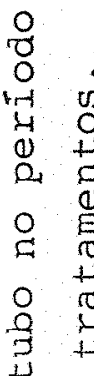

$\begin{array}{ll}0 \\ 0 & 1 \\ 0 & 0 \\ 0 & 0\end{array}$

$\stackrel{\circ}{+}$

$\begin{array}{ll}0 & 0 \\ 1 & 0 \\ 0 & 0 \\ 0.1 & 0\end{array}$

$\begin{array}{ll}0 & 0 \\ 0 & 0 \\ 0 & 0 \\ 0 & 1 \\ 0 & 0 \\ 0 & 0 \\ 0 & 0 \\ 0 & 1\end{array}$

थ $\stackrel{-1}{\Xi}$

\%

$-\frac{1}{3} 0$

$\underset{r \rightarrow d}{\sigma}$ is

is 2

点

$\ddot{\sim}$

end

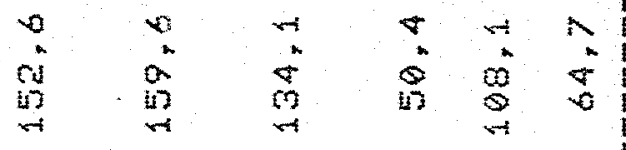

in $a$ a $p o$

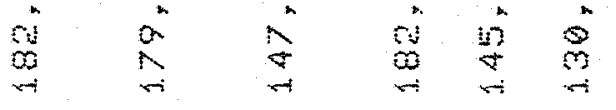

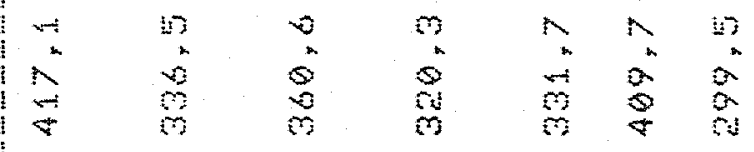

:

a

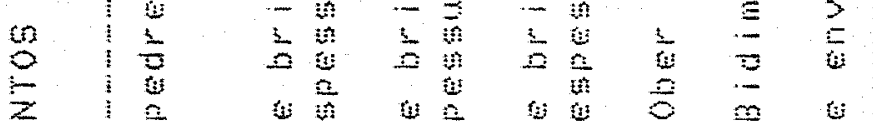

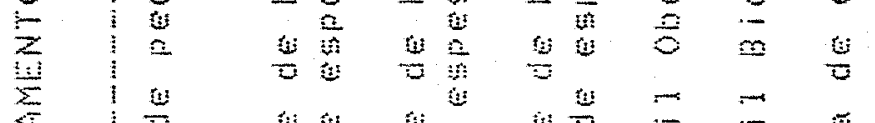

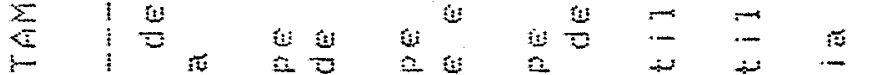

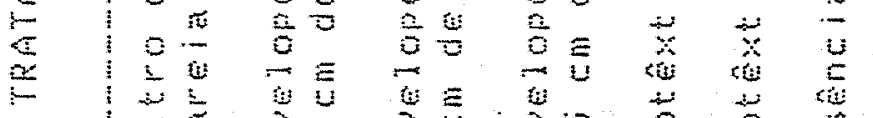

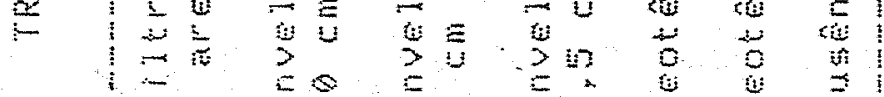

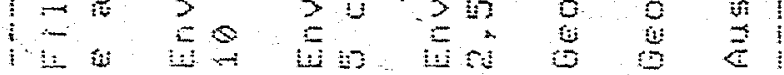

